\title{
DIEGO RAIGORODSKY
}

O Talmud Babilônico e o estabelecimento da lei: uma exposição dos métodos hermenêuticos empregados pelos sábios amoraítas 



\title{
DIEGO RAIGORODSKY
}

\section{O Talmud Babilônico e o estabelecimento da lei: uma exposição dos métodos hermenêuticos empregados pelos sábios amoraítas VERSÃO CORRIGIDA}

\begin{abstract}
Dissertação apresentada como requisito para obtenção do grau de mestre no curso de pós-graduação em Letras, área de concentração: Língua Hebraica, Literatura e Cultura Judaicas, da Faculdade de Filosofia, Letras e Ciências Humanas da Universidade de São Paulo, em setembro de 2015, sob a orientação do Prof. Dr. Moacir Amâncio.
\end{abstract}

São Paulo 






\section{AGRADECIMENTOS}

Ao Prof. Dr. Moacir Amâncio, por sua atenção e apoio durante o processo de pesquisa e escrita deste trabalho.

Ao Prof. e amigo Jairo Fridlin, por todo seu incentivo e apoio para que eu crescesse e me desenvolvesse cada vez mais, tanto no âmbito intelectual como profissional.

Ao Rabi Chaim Brovender, por me permitir livre acesso às aulas em sua Ieshivá, e por disponibilizar todo seu conhecimento para que eu pudesse redigir este texto.

Ao Rabi David Fink, por ter me iniciado no mundo talmúdico.

Ao Rabi Yehoshua Geller, por ter me iniciado no mundo da halachá. 



\section{RESUMO}

\section{RAIGORODSKY, D. O Talmud Babilônico e o estabelecimento da lei: uma análise dos}

métodos hermenêuticos empregados pelos sábios amoraítas. 2015. 147 p. Dissertação (Mestrado) - Faculdade de Filosofia, Letras e Ciências Humanas, Universidade de São Paulo, São Paulo, 2015.

Esta dissertação destaca os métodos de interpretação usados pelos sábios amoraítas para interpretar a Torá e definir a lei religiosa judaica. Este trabalho visa a entender como o texto da Torá serve como base para discussões legais por parte dos sábios e, por consequência, entender que abordagens tais sábios usavam para explicar e esclarecer os significados obscuros do texto bíblico. Para tanto, procedeu-se a um estudo sobre o desenvolvimento da Torá Oral no judaísmo rabínico e a uma análise crítica das obras clássicas da Torá Oral, a saber, a Mishná e o Talmud, sempre tendo como pano de fundo o texto da Torá Escrita. A pesquisa mostra como a aplicação dos métodos hermenêuticos por parte dos sábios amoraítas é, até certo ponto, altamente subjetiva e como isso ajudou a definir a lei religiosa judaica que é seguida até hoje por judeus ortodoxos.

PALAVRAS-CHAVE: Torá Escrita, Torá Oral, Talmud, Amoraítas, Hermenêutica. 



\begin{abstract}
RAIGORODSKY, D. Babylonian Talmud and the establishing of the law: an analysis of the hermeneutical methods used by the amoraite Sages. 2015. 147 p. Dissertação

(Mestrado) - Faculdade de Filosofia, Letras e Ciências Humanas, Universidade de São Paulo, São Paulo, 2015.

This dissertation highlights the methods of interpretation used by the Amoraitic Sages to interpret the Torah and establish the Jewish religious law. This work aims to understand how the text of the Torah serves as a basis for legal discussions undertaken by the Sages and therefore tries to understand the approaches that such Sages used to explain and clarify the obscure meanings of the biblical text. In order to achieve that, we have proceeded to a study of the development of the Oral Torah in rabbinic Judaism and a critical analysis of classic works of the Oral Torah, namely the Mishnah and Talmud, besides the text of the Written Torah as a background. The research shows how the application of hermeneutical methods by the Amoraitic Sages is, to some extent, highly subjective and how it helped to define Jewish religious law that is followed even today by Orthodox Jews.
\end{abstract}

KEYWORDS: Written Torah, Oral Torah, Talmud, Amoraites, Hermeneutics. 



\section{SUMÁRIO}

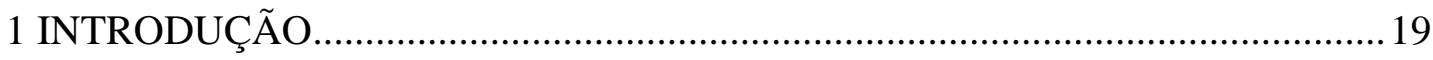

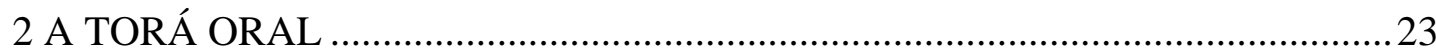

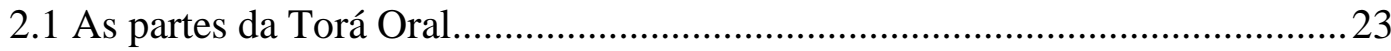

2.2 As principais fontes para estudo da Torá Oral ..............................................25

2.2.1. Primeiros indícios da Torá Oral como elemento regulador das leis.........27

2.2.2 A época da Mishná, a primeira obra compilada da Torá Oral .................. 30

3 DE ONDE VEM A AUTORIDADE RABÍNICA PARA DEFINIR A LEI............33

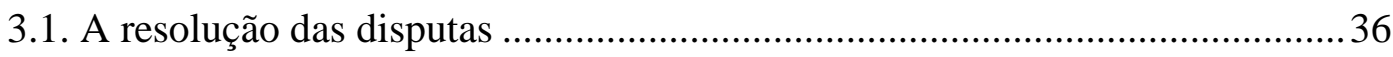

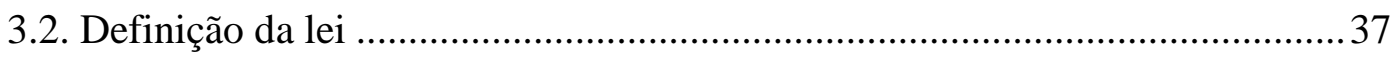

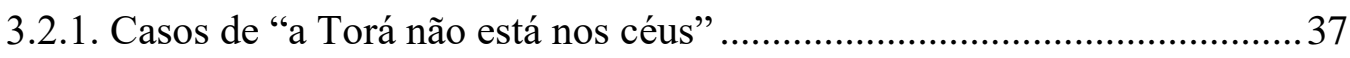

3.2.2. A diferença do estudo da Torá e da lei promulgada no tribunal ...............39

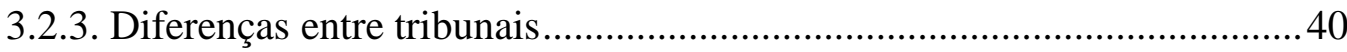

3.3. Diferenciação de leis da Torá e dos Rabinos ................................................40

3.3.1. Características gerais e relevância....................................................... 41

3.3.2. Diferenças práticas entre as duas classes de mandamentos ..................... 42

3.3.3. As punições de leis rabínicas.................................................................. 44

4 CRIAÇÕES RABÍNICAS NO ÂMBITO DA LEI - TAQANOT, GUEZEROT, ETC

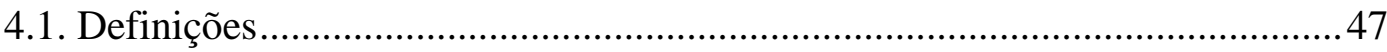

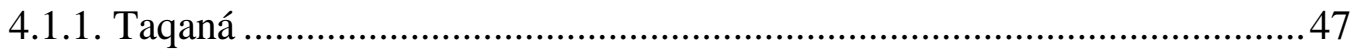

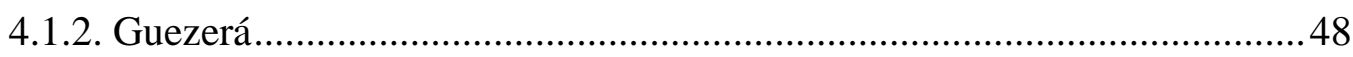

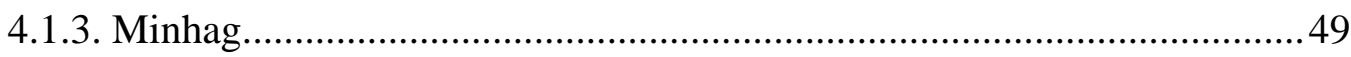

4.2. Autoridade dos sábios para decretar taqanot, guezerot e minhaguim .............50

4.3. Limitações do poder rabínico em emitir decretos ............................................53

4.3.1. Shev veal taassê (Senta e não faças) .....................................................53 
4.3.2. Qum assê (Levanta e faça) 54

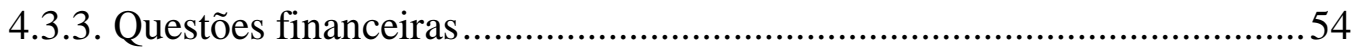

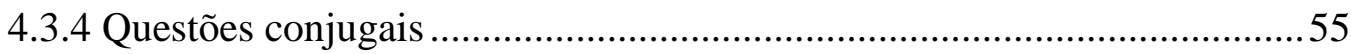

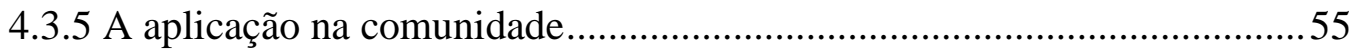

5 MÉTODOS DE EXPLICAÇÃO DA TORÁ PARA DEFINIR A LEI.....................57

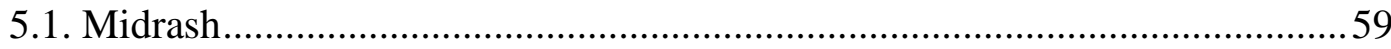

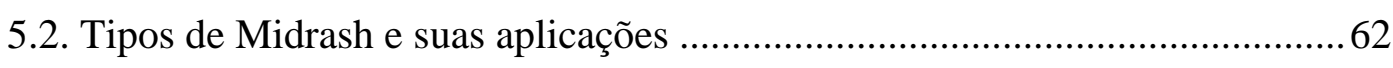

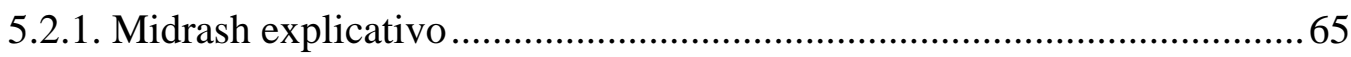

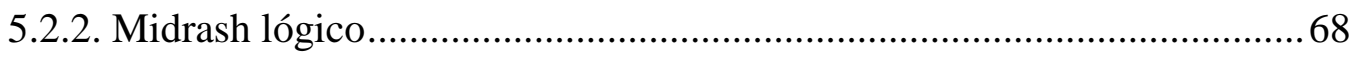

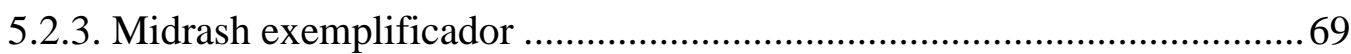

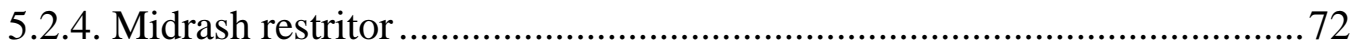

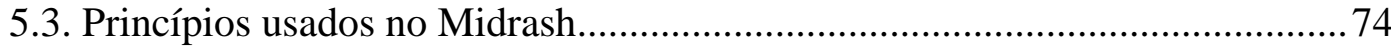

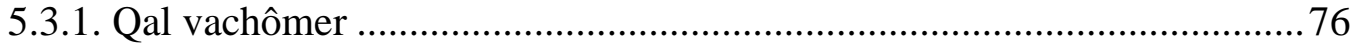

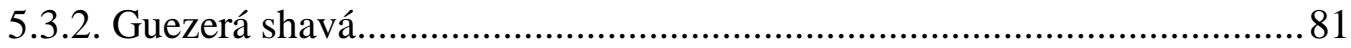

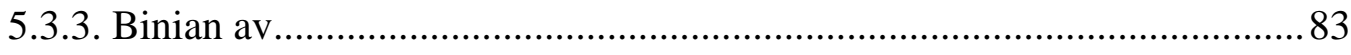

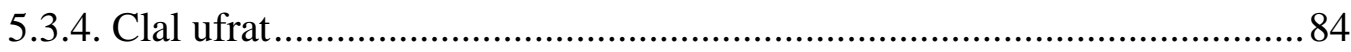

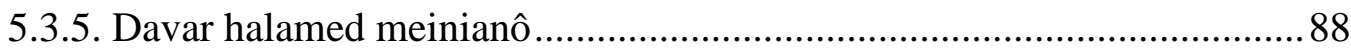

5.3.6. Shnê ktuvim hamachchishim ze et ze................................................. 90

6 DIVERGÊNCIAS NO USO DO MIDRASH .................................................... 93

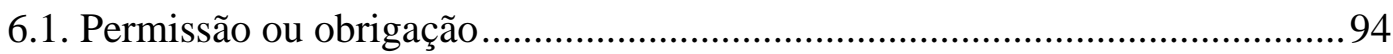

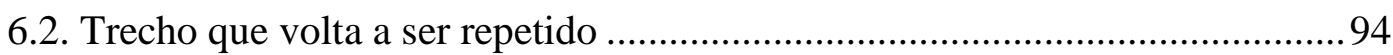

6.3. A diferença no uso do midrash e suas consequências ...................................95

7 OS SÁBIOS DO TALMUD E AS LEIS ESTABELECIDAS NA MISHNÁ .........97

7.1. Um amoraíta jamais discorda de um tanaíta ................................................97

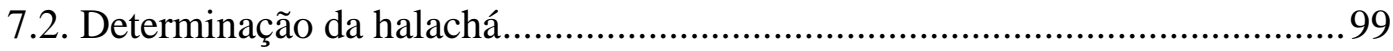

7.2.1. Princípios na definição da lei ...................................................................99

7.2.2. A definição da lei em casos singulares e sua linguagem........................ 100 
7.2.3. A definição da lei por meio da negação 102

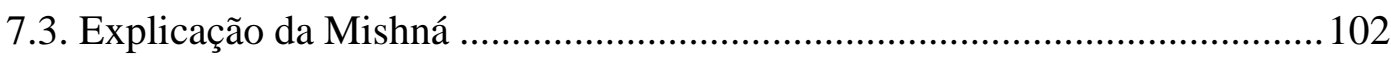

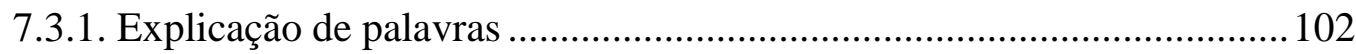

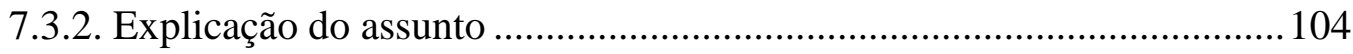

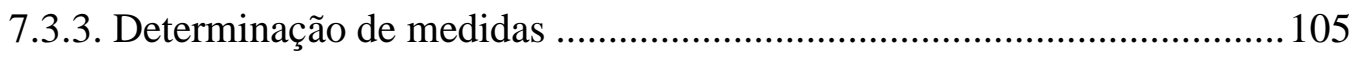

7.3.4. Explicação da razão de ser de uma lei................................................. 105

7.3.5. Busca de uma fonte para a lei............................................................ 106

7.3.6. Busca de uma causa para a lei ........................................................... 108

7.4. Restrição ou ampliação da lei estabelecida na Mishná ................................ 109

7.4.1. Restrição da lei estabelecida na Mishná.............................................. 110

7.4.2. Ampliação da lei estabelecida na Mishná ..............................................112

7.5. Precisão com relação à linguagem da Mishná.............................................. 112

7.5.1. Precisão com relação à linguagem literal da Mishná ............................. 112

7.5.2. Precisão com relação a redundâncias na Mishná .................................... 113

7.5.3. Precisão com relação a contradições na Mishná ..................................... 115

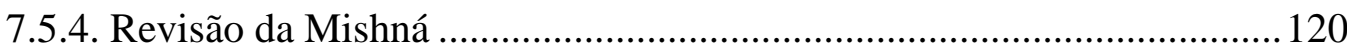

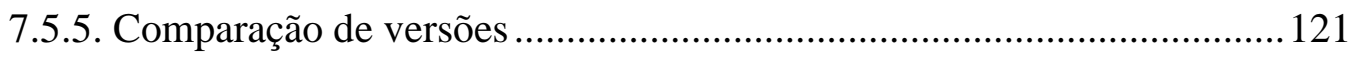

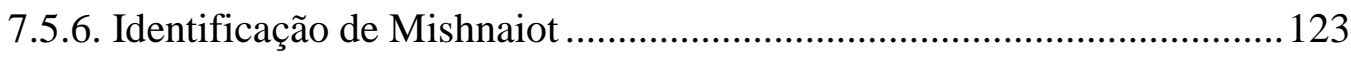

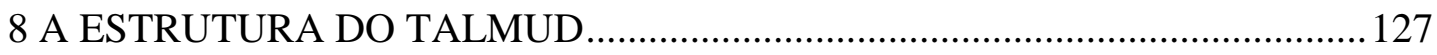

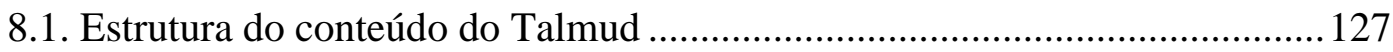

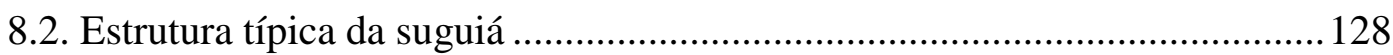

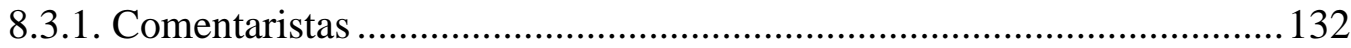

8.3.2. Referências e revisões ....................................................................... 132

8.4. Tradução "plana” da folha mostrada (Meguilá 25a) .................................... 133

8.5. Tradução crítica da folha mostrada (Meguilá 25a) ....................................... 135

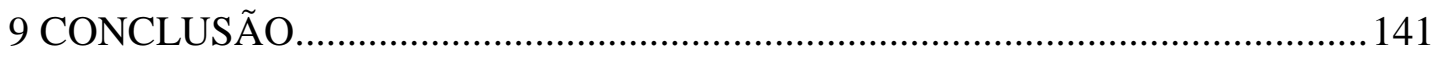





\section{INTRODUÇÃO}

Segundo a tradição judaica, a Torá ${ }^{1}$ foi dada a Moisés no Monte Sinai para servir como fonte de instrução permanente ao povo judeu.

Assim, a Torá é reconhecida por todo o povo judeu, independente do grau de observância do praticante, e assim tem sido ao longo das gerações e da história. A maior parte do texto da Torá é composto de histórias e narrativas (fortemente inspiradas em lendas)²; e apenas uma pequena parte dela gira em torno de leis e mandamentos, mas é justamente esta a parte que será analisada neste trabalho. O conjunto de leis e mandamentos contidos na Torá é o que se convencionou chamar de Halachá. ${ }^{3}$

A parte legalista da Torá - a parte de Halachá da Torá - é, na verdade, além de pequena, extremamente curta e concisa. Isso significa que para que daí se obtenha um sistema legal de fato, um código de leis que possa servir na prática religiosa cotidiana, faz-se necessário um grande acréscimo de comentários e explicações sobre o que está escrito no texto bíblico. Este conjunto de comentários e explicações é o que se chama Torá Oral.

Segundo a tradição judaica, a importância da Torá Oral é a mesma que da Torá Escrita, e ambas formam um todo indissociável e complementar. Na verdade, do ponto de vista da tradição, ambas teriam sido dadas ao Povo de Israel por meio de Moisés já no Monte Sinai. ${ }^{4}$

Independentemente da veracidade dessa afirmativa, fato é que sem a Torá Oral - ou seja, sem um corpo de comentários e explicações -, não é possível seguir as leis detalhadas na Torá Escrita segundo o judaísmo rabínico. No entanto, sendo de uma natureza mais subjetiva, não se pode dizer que a Torá Oral desfrute da mesma aceitação e reconhecimento que a Torá Escrita entre todos os grupos judaicos. Ao contrário de sua contraparte textual, quando se trata

\footnotetext{
${ }^{1}$ Pentateuco, ou Cinco Livros de Moisés: Gênesis, Êxodo, Levítico, Números e Deuteronômio.

${ }^{2}$ Cf., por exemplo, CAMPBELL (1991). The Masks of God: Occidental Mythology, p. 109.

${ }^{3} \mathrm{Da}$ raiz hebraica halach (ir, caminhar), supostamente porque é segundo essa lei que as pessoas devem caminhar, se portar.

${ }^{4}$ No entendimento acadêmico contemporâneo, a tradição do que veio a se chamar Torá Oral se desenvolveu ao longo de gerações entre os habitantes da Judeia em algum momento antes do Exílio Babilônico (circa 530 a.e.c.). Essa tradição foi passada por meio de diversos mecanismos de transmissão cultural, incluindo, mas não restrito à transmissão oral. Cf. Herbert (2012), pp. xvii-xix.
} 
da Torá Oral nota-se que, ao longo da história, houve diversos grupos que a rejeitaram - total ou parcialmente.

Desde a época dos fariseus já havia algum tipo de oposição a uma “Torá Dual”, embora hoje apenas o reduzido grupo dos caraítas ${ }^{5}$ se opõe formalmente à incorporação de qualquer lei extra-bíblica em sua prática religiosa. ${ }^{6}$

Muito provavelmente, a ideia de que tanto a Torá Oral como a Torá Escrita foram dadas a Moisés no Sinai surge justamente como uma tentativa de conter o fenômeno de rejeição da Torá Oral por parte de alguns grupos judaicos; que se configura em um problema religioso bastante complexo. A lógica por trás dessa ideia é fácil de entender: passa-se a acreditar que uma Torá não seria posterior a outra e ambas foram dadas pelo próprio Deus a Moisés, então não há motivo para rejeitar a Torá Oral, já que ela teria vindo diretamente do Sinai e seria tão autêntica quanto a Torá Oral.

\begin{abstract}
"Estes são os estatutos e os juízos e as leis que o Eterno deu entre Si e os filhos de Israel” (Levítico 26:46). "Os estatutos” são as casas de estudo. "Os juízos” são os tribunais. E "as leis" mostra que duas leis foram dadas a Israel, uma por escrito e outro de maneira oral... "no Monte Sinai, através de Moisés" (idem). Isso mostra que a Torá com todas suas leis, regras e explicações foram dadas por Moisés no Sinai.
\end{abstract}

$\left(\right.$ Sifra $^{7}$, Bechucotai, Capítulo 8:12). ${ }^{8}$

Apesar de essa ideia ser difundida nos círculos rabínicos e de existirem várias fontes como a citada, é possível encontrar outros textos da tradição - alguns Midrashim $^{9}$ - que contradizem essa tese, e mencionam casos de sábios ${ }^{10}$ explicando coisas sobre a Torá Escrita que não foram ditas nem a Moisés no Sinai. Assim, por exemplo, conta-se que o Rabi Eliezer "sentava-se e explicava coisas ainda maiores do que as que foram ditas a Moisés no Sinai; e

\footnotetext{
${ }^{5}$ Estima-se que hoje existam cerca de 45.000 caraítas em todo mundo, frente a 1,7 milhões de judeus ortodoxos seguidores do judaísmo rabínico (fonte: site do Caraísmo Mundial - www.karaite-korner.org. Último acesso em dezembro de 2014). Além desses dois grupos, judeus em diferentes partes do mundo se definem basicamente como "conservadores", "reformistas" ou "seculares". Em 2013, estimava-se que havia 14 milhões de judeus em todo mundo (fonte: World Jewish Population, 2013).

${ }^{6}$ Para uma visão mais geral e abrangente sobre a aceitação da Torá Oral dentro dos diferentes grupos judaicos, Cf. Cardozo (1989) e Student (2001). Dentre os grupos históricos mais conhecidos por rejeitarem de alguma maneira a Torá Oral, encontram-se os saduceus (Koltun-Fromm, 2006), os essênios (Fitzmyer, 2009) e os samaritanos (Lowy, 1977).

${ }^{7}$ Palavra aramaica, lit. "livro". É o livro de comentários homiléticos (midrash, cf. n. 9 abaixo) sobre Levítico. Na referência, comentários sobre a porção semanal da Torá chamada Bechucotai (heb., "em Minhas leis"), que compreende Levítico 26:3 a 27:34.

8 Todas as citações de fontes hebraicas contidas nesse trabalho foram traduzidas por mim mesmo. Isso é válido inclusive para a tradução de versículos bíblicos, nos quais, no entanto, também me fiei nas traduções de Almeida, da Bíblia de Jerusalém e da Bíblia Hebraica da Editora Sêfer.

${ }^{9}$ Comentários e interpretações bíblicas homiléticas, muitas vezes baseados em metáforas e lendas.

${ }^{10}$ Nome genérico usado para se referir aos rabinos mencionados na Mishná e no Talmud.
} 
seu rosto se iluminava como a luz do sol" (Avot de Rabi Natan, ${ }^{11}$ Fórmula 2, Capítulo 13).

Notando esta contradição entre as duas ideias - a Torá Oral ter sido dada inteira a Moisés vs. sábios explicando coisas que Moisés não sabia - vários foram os textos escritos com o intuito de explicar o tema. Um bom exemplo é o seguinte Midrash, que propõe uma resposta para solucionar a problemática em questão:

Por acaso Moisés aprendeu toda a Torá? Justo ela, sobre a qual se disse: "Sua dimensão excede à da terra e é maior que a vastidão do mar" (Jó 11:9)? Moisés ficou (apenas) quarenta dias estudando! Tudo o que o Santíssimo, bendito seja, ensinou a Moisés foram princípios gerais. Por isso foi dito "E deu a Moisés, ao acabar de falar generalidades com ele no Monte Sinai, duas tábuas de Testemunho" (Êxodo 31:18).

(Shemot Rabá, 41:6). ${ }^{12}$

Textos como esse (e outros vários similares) serviram de base para que parte dos sábios assumisse essa como a postura "oficial” quanto à transmissão da Torá. Passou-se a considerar que os princípios gerais estabelecidos na Torá foram dados a Moisés, tanto por escrito como oralmente, mas que, mesmo assim, os sábios das gerações posteriores discutiam, esclareciam e elucidavam o texto com suas inovações, desconhecidas de Moisés, para assim poder definir a prática normativa religiosa - a Halachá.

\footnotetext{
${ }^{11}$ Análise homilética e exegética do tratado de Avot (Ancestrais), atribuída ao Rabi Natan, embora provavelmente ele não tenha sido seu único autor.

12 Shemot Rabá é a coletânea de midrashim (pl. de midrash, v. nota 9 supra) do livro do Êxodo (Shemot, em hebraico).
} 



\section{A TORÁ ORAL}

\subsection{As partes da Torá Oral}

Sendo um vasto corpo de comentários sobre a Torá Escrita que foi surgindo ao longo do tempo - fruto das mentes mais diversas, dos mais diversos locais $-{ }^{13}$ não é de se estranhar que a Torá Oral seja extremamente multifacetada. No entanto, isso não evitou que teóricos do judaísmo tentassem sistematizar o corpo de conhecimento da Torá Oral e, para tanto, foram propostos vários modelos. Como mencionado anteriormente, essa sistematização pode ter sido feita com o objetivo de justificar a existência da Torá Oral e aumentar sua aceitação e cumprimento por parte dos diferentes grupos judaicos no mundo.

Em um dos modelos mais famosos, o Rambam, ${ }^{14}$ na introdução ao seu livro de comentários à Mishná, ${ }^{15}$ divide em cinco as partes constituintes da Torá Oral. ${ }^{16}$ Eis o que ele diz:

Vemos, conforme os princípios gerais que acabamos de estabelecer, que todas as leis estabelecidas na Torá se dividem em cinco partes.

A primeira parte são as que derivam dos comentários recebidos de Moisés, e que estão aludidos de algum modo no texto escrito, ou que se podem aprender dos métodos. ${ }^{17}$ Quanto a essas leis não há divergência alguma, e toda vez que uma pessoa diz "eu recebi esta lei assim e assado" dissipa-se qualquer tipo de divergência que possa existir.

\footnotetext{
${ }^{13}$ Cf. nota 4, supra.

${ }^{14}$ Rabi Moisés ben Maimon, ou Maimônides (Espanha, 1135 - Egito, 1204).

${ }^{15}$ Livro de coletânea de leis da Torá Oral, que foram passadas de mestres para discípulos e que foram compiladas pelo Rabi Iehudá Hanassí, por volta de 200 e.c. A Mishná [lit. "estudo pela repetição"] é dividida em seis "ordens", cada ordem em "tratados", cada tratado em "capítulos" e cada capítulo em "mishnaiot". Assim, o termo "mishná" pode se referir à obra como um todo, ou aos trechos específicos dentro dos capítulos. Neste trabalho, quando a referência for à obra como um todo, grafar-se-á Mishná. Quando a referência for a um trecho ou lei específica citada na obra, usar-se-á mishná. Essa divisão se baseia na distinção feita por Bacher (1922, p. 84).

${ }^{16}$ Para um modelo mais contemporâneo e acadêmico, cf. o verbete "Oral Law" na Enciclopédia Judaica, onde se propõe uma divisão da Torá Oral em oito partes.

${ }^{17}$ A referência é aos métodos pelos quais a Torá pode ser interpretada (ver adiante).
} 


\begin{abstract}
A segunda parte são as leis chamadas de "Halachá dada a Moisés no Sinai". ${ }^{18}$ Essas são leis para as quais não temos provas [lógicas que expliquem o seu significado], e quanto a estas também não há qualquer tipo de divergência.

A terceira parte são as leis derivadas de um dos métodos e nas quais se aplica a possibilidade de divergência, como já foi dito. Nestes casos, a decisão legal é feita com base na opinião da maioria, seguindo os princípios gerais que estabelecemos anteriormente... E, mesmo assim, a divergência aqui só se aplica nos casos em que não temos um tradição que foi recebida e transmitida...

A quarta parte é composta pelas leis estabelecidas pelos profetas e pelos sábios de todas e cada uma das gerações, na tentativa de estabelecer limites à Torá e evitar que as pessoas cometam transgressões... Aqui estão as leis que chamamos de "Decretos dos sábios", e nelas também é possível haver divergência.

A quinta parte são as leis que foram estabelecidas na tentativa de trazer ordem a certos assuntos ou áreas da vida humana e que são coisas que não se constituem em um acréscimo ou exclusão de palavras da Torá. Pode ser também que venham retificar certas questões no mundo, no que diz respeito à religião. Há os que chamam esses tipos de leis de "regulamentos" e "costumes" dos sábios. É proibido transgredir esse tipo de lei, de qualquer modo que seja, e todo mundo é obrigado a cumpri-las.
\end{abstract}

(Rambam, Pêrush Hamishnaiôt, Introdução).

Pode-se ver que o Rambam faz uma divisão mais geral em duas partes: os itens um e dois são compostos de leis que teriam sido dadas a Moisés no Sinai, sendo que o primeiro tipo é composto por leis que estão claras no texto ou que podem ser entendidas usando métodos de hermenêutica; e o segundo tipo seria de leis que não possuem um sentido lógico que justifiquem o seu cumprimento. Para esses dois grupos de leis, o Rambam não aceita a existência de divergência, de debates e a possibilidade de diferentes interpretações quanto aos seus significados e cumprimento normativo.

A propósito, parece necessário lembrar que, segundo Chait, ${ }^{19}$ a hermenêutica rabínica é intrínseca à epistemologia e, portanto, qualquer análise textual dentro da tradição judaica tem por pano de fundo mais uma questão espistêmica que uma questao hermenêutica. Na visão tradicional, o estudo da Torá seria equivalente a compreender as ideias de Deus e, por consequência, o estudo do Talmud seria similar a estudar os pensamentos da divindade, daí o seu valor epistemológico. Isso faz com que a hermenêutica rabínica ocupe uma posição singular frente à hermenêutica geral. Prova disso é a constatação de que a hermenêutica rabínica possui seus próprios modos de funcionamento e objetivos, que poderiam ser considerados como "estranhos" ou "absurdos" para a hermenêutica contemporânea ou ao leitor moderno. Essa singularidade hermenêutica pode explicar por que o Rambam defende que as leis interpretadas por meio desse modo de análise não aceitam divergência.

Retomando o modelo de divisão da Torá Oral proposto, num segundo grupo, podem-

\footnotetext{
${ }^{18}$ Para mais detalhes, ver adiante.

${ }^{19} \mathrm{Cf}$. em especial o Adendo I.
} 
se colocar as três últimas classes de leis citadas pelo Rambam: decretos e regulamentos estabelecidos pelos sábios, bem como decisões legais tomadas por eles em casos de divergências de opiniões. Nesses três pontos temos a verdadeira produção intelectual dos sábios no âmbito da Torá Oral e são esses comentários e leis as partes mais importantes da Torá Oral, muitas vezes considerados o seu âmago e sua essência.

Interessante notar que é justamente por conta de diferenciações como essa do Rambam que hoje se costuma falar em mitsvot deoraita (aramaico para "preceitos da Torá") e mitsvot derabanan (aramaico para "preceitos dos sábios"). Isso tem uma importância legal que será discutida adiante. Assim, por exemplo, a lei que proíbe a realização de trabalho no Shabat é deoraita, pois seria parte do primeiro grupo, por estar explícita no texto da Torá: "mas o sétimo é o Shabat [...] no qual [...] não farão nenhuma obra" (Êxodo 20:10). Mas, por outro lado, o preceito de acendimento das velas na festa de Chanucá, por exemplo, tem origem no dito dos sábios (Talmud ${ }^{20}$, Shabat $^{21} 21 \mathrm{~b}$ e outros) e, portanto, é um preceito derabanan (aramaico, “dos sábios”).

Obviamente, no entanto, nem sempre a distinção entre os dois tipos de lei é assim clara, pois às vezes um mandamento é criado através da interpretação que os sábios fazem de um versículo da Torá. A questão que surge, então, é: o fato de o mandamento ser baseado em uma interpretação rabínica o torna um mandamento derabanan ou o fato de ele ser baseado em um versículo da Torá permite que digamos que se trata de um mandamento deoraita $?^{22}$

\subsection{As principais fontes para estudo da Torá Oral}

Por mais paradoxal que possa parecer, o nosso conhecimento atual da Torá Oral vem de livros escritos. O nome "Torá Oral" vem do fato de que, supostamente, por muito tempo esses conhecimentos foram transmitidos exatamente dessa maneira, oralmente, dentro das casas de estudo judaicas. ${ }^{23,24}$

\footnotetext{
${ }^{20}$ O Talmud [lit. "aprendizado"] é um texto central do judaísmo rabínico, dividido em seis ordens e sessenta e três tratados. Cada tratado é composto por duas partes: a Mishná (Cf. n. 15, supra) e a Guemará, uma elucidação do texto da Mishná e da Bíblia Hebraica.

${ }^{21} \mathrm{Um}$ dos 63 tratados do Talmud, que lida basicamente com as leis do Shabat.

${ }^{22}$ Para uma discussão mais aprofundada sobre o tema, Cf. Guilat (1958), pp. 401-418.

${ }^{23}$ Cf. supra, n. 4.

${ }^{24}$ As casas de estudo judaicas são chamadas de Beit Midrash (בית מדרש) em hebraico. Na maioria das vezes, tratase de uma sala com bancos e mesas simples para o estudo da Torá. Assim, é comum encontrar batê midrash [plural]
} 
Foge ao objetivo deste trabalho analisar o motivo que levou esse tipo de ensinamento essencialmente oral a ser passado para material escrito, mas fato é que se isso não tivesse ocorrido, hoje é duvidoso se teríamos alguma fonte da tradição oral preservada (Cf. TELUSHKIN, pp. 146-152). ${ }^{25}$

Um desses livros que possibilitou a preservação dos ensinamentos orais, e que é considerado base para outras obras que viriam posteriormente, é a Mishná. ${ }^{26}$ Para os fins desta pesquisa, a Mishná será tratada como o livro editado pelo Rabi Iehudá Hanassí, no qual estão registradas centenas de discussões sobre a lei, e a opinião legal de diversos sábios sobre assuntos dos mais variados. No entanto, segundo Albeck (2005), a definição de Mishná é mais abrangente, e seria "tudo aquilo que foi ensinado oralmente como complemento à Torá Escrita, incluindo comentários e interpretações da Torá (Midrash) e leis e regulamentos que não estão especificados na Torá (Halachá)".

Quando se fala da Mishná, é importante ressaltar que as leis trazidas e estabelecidas nela não são identificadas segundo a sua origem, isto é, não há referência alguma se são leis da Torá Escrita - deoraita ou da Torá Oral - derabanan. Apenas o conhecimento do leitor é que permitiria diferenciar quando os sábios estão falando em nome de sua escola e tradição, ou em nome do texto propriamente dito. ${ }^{27}$

Outro livro base da Torá Oral, contendo um enorme registro dos ensinamentos dos sábios e suas escolas, é o Talmud, que possui duas versões: a Babilônica e a de Jerusalém.28

dentro das sinagogas propriamente ditas.

${ }^{25}$ É interessante notar que o próprio Talmud (Guitin 60b) afirma que a Torá Oral não deve ser escrita.

O Midrash (Shemot Rabá 47:1) afirma que essa proibição tinha por objetivo fazer com que a Torá fosse uma posse exclusivamente judaica. Os gentios tinham acesso à Torá Escrita (principalmente por sua tradução grega), mas enquanto a Torá Oral fosse transmitida apenas desse modo, esse corpo de ensinamento ficaria indisponível a eles. Maimônides (Guia dos Perplexos 1:71) afirma que a proibição existia pois ao manter a Torá transmitida oralmente prevenia-se a criação de discordâncias da lei, pois um texto escrito está mais sujeito a ser interpretado erroneamente.

Apesar das proibições, especula-se que a Torá Oral começou a ser escrita com um objetivo duplo: (1) evitar que ela fosse esquecida após a destruição do Templo e a diáspora judaica e (2) permitir que a Torá Oral crescesse, se expandisse e fosse disseminada.

${ }^{26}$ Cf. supra, n. 15.

27 Tão importante quanto a Mishná e contemporânea a ela é a Tossefta [lit. "suplemento, adição"]. Foi redigida pelo Rabi Chia e pelo Rabi Ochaia. É usada hoje basicamente como texto comparativo para a Mishná, pois muitas vezes a Tossefta detalha um ponto que ficou pouco claro na Mishná, ou discorda dele quanto à uma definição legal, ou à autoria de um ensinamento. Cf. (Albeck, H. Studies in Baraita and Tosephta. Jerusalem: Mossad HaRav Kook, 1969).

${ }^{28}$ O processo de compilação dos ensinamentos rabínicos antigos ocorreu no que eram dois centros judaicos da época: Galileia e Babilônia, originando, portanto, duas versões do Talmud. A versão de Jerusalém é mais antiga (tendo sido compilada por volta do século IV c.e.), sendo a Babilônica de cerca de um século mais tarde. Ambos foram escritos em aramaico, no entanto existem diferenças dialetais entre o idioma de cada versão. Nenhum dos dois Talmud analisa todas as leis da Mishná, mas o Talmud de Jerusalém é o único a analisar as leis do tratado de Zeraim (sementes), principalmente porque esse volume se dedica a leis agrícolas que só se aplicavam na Terra de Israel, e não no exílio, na Babilônia. Por outro lado, apenas o Talmud da Babilônia analisa o tratado de Codashim, 
Ambas são, por assim dizer, comentários e explicações sobre o texto curto, conciso e, muitas vezes, críptico, da Mishná.

Os sábios que aparecem no texto da Mishná ficaram conhecidos como sábios tanaítas. ${ }^{29}$ Já os sábios do Talmud, posteriores a esses, foram chamados de sábios amoraítas. ${ }^{30}$ Neste trabalho analisar-se-á principalmente como os sábios amoraítas se aproximaram do texto tanaítico para definir a legislação judaica.

2.2.1. Primeiros indícios da Torá Oral como elemento regulador das leis

Referências à Torá Oral e seu uso como agente definidor da Halachá podem ser encontradas não só nos livros da Torá, mas também nos livros dos Profetas e dos Escritos, e elas, talvez, sejam as provas mais antigas que temos sobre a influência e importância dos comentários dos estudiosos do texto sagrado no que concerne à aplicação da lei (Cf. "Oral Law", In: Enciclopédia Judaica. URBACH, 1947).

Como exemplo, analisar-se-á brevemente um assunto central no judaísmo: o Shabat. Justamente por causa de sua importância na vida judaica, este é um dos temas que mais possui leis ligadas a ele, seja na Torá Escrita, seja na Torá Oral.

No texto da Torá, já na história da criação, no começo de Gênesis, há uma referência ao sétimo dia e a como ele foi abençoado e santificado por Deus (Gênesis 2:3). Mais adiante, na enunciação dos Dez Mandamentos (em suas duas versões), um deles ordena que o povo se lembre do Shabat e o guarde, por dois motivos: 1) porque "o Eterno fez os céus e a terra, o mar e tudo o que há neles em seis dias e repousou no sétimo dia” (Êxodo 20:11); e 2) para “lembrar que servo foste na terra do Egito” (Deuteronômio 5:15).

Curiosamente, embora a primeira menção explícita sobre a obrigatoriedade de se guardar o dia de Shabat esteja ligada ao evento da entrega da Torá no Sinai e os Dez Mandamentos, na prática podemos ver que se considerarmos o texto bíblico como linear, já

\footnotetext{
que se relaciona com leis de sacrifícios e rituais do Templo de Jerusalém. Isso é estranho, pois tais leis já não eram relevantes em nenhum dos dois países quando da compilação dos Talmud e, especialmente, não na Babilônia.

${ }^{29}$ Do aramaico, lit. "aqueles que ensinam" ou, alternativamente, "aqueles que repetem". Sábios judeus que ensinavam por meio da repetição os ensinamentos da Torá Oral. Viveram entre 10 e 220 d.e.c., principalmente na Terra de Israel, nas cidades de Jerusalém e Iavne. Cf. SCHARFSTEIN, 2008, p. 523.

${ }^{30}$ Do aramaico, lit. "aqueles que falam" ou "aqueles que dizem ao povo"; "porta-vozes". Sábios judeus que falavam ou diziam ao povo quais eram os ensinamentos da Torá Oral. Viveram entre 200 e 500 d.e.c. na Babilônia e em Israel. Cf. SCHARFSTEIN, 1996, p. 116.
} 
existe um mandamento ligado ao dia de Shabat que é dado ao povo ainda antes da entrega da Torá, e isso é algo particularmente excepcional.

Durante a caminhada pelo deserto o texto bíblico relata que o povo recebia o maná durante seis dias da semana e, no sexto dia, todos deveriam pegar duas porções, pois o maná não seria encontrado no campo no sétimo dia. Nesse ponto do texto aparece um mandamento explícito que Moisés transmite ao povo e é ligado ao sétimo dia: "Ficai cada um em seu lugar; que ninguém saia de seu lugar no sétimo dia" (Êxodo 16:29).

Além da obrigatoriedade de guardar e lembrar o sétimo dia, e de "ficar cada um em seu lugar", existem outros mandamentos ligados ao dia de Shabat no texto da Torá, embora eles sejam bem menos específicos do que os já mencionados: "não farão nenhuma obra" (Êxodo 20:10); "no sétimo dia folgarás" (Êxodo 23:12); "guardareis o dia de Shabat” (Êxodo 31:14) e "no sétimo dia haverá para vós santidade, Shabat de repouso ao Eterno; todo aquele que nele fizer trabalho será morto" (Êxodo 35:2).

Isso é basicamente tudo que se tem na Torá a respeito do dia de Shabat. No entanto, saindo do âmbito do Pentateuco, vê-se que nos livros dos profetas também existem alusões ao dia de Shabat e exortações junto ao povo para o seu cumprimento. Por exemplo, Isaías diz: "Louvável é aquele que assim se porta e o homem que nisto se firma; que guarda o dia de Shabat para não o profanar" (Isaías 56:2) e "Se deixares de espezinhar o dia de Shabat $e$ o fizeres com boa vontade, em homenagem a Meu santo dia, e chamares o dia de Shabat de deleitoso e o honrares, não seguindo os maus caminhos...” (Isaías 58:13).

Em um trecho do livro de Amós (5:8) temos o hipotético discurso de um perverso do povo reclamando por conta da proibição de trabalhar no dia de Shabat, citando atos específicos que, ficamos sabendo, eram vetados ao povo: "Quando se irá a lua nova para que possamos vender grão, e o sábado, para que possamos expor o trigo, reduzindo sua medida e aumentando seu preço?".

Na descrição de Amós o homem perverso pergunta quando o dia de Shabat irá terminar para que ele possa se ocupar novamente com o comércio, comprando e vendendo mercadorias. Ora, isso é muito interessante já que na Torá propriamente dita não há nenhuma proibição explícita particularmente dirigida ao comércio. Assim, deste trecho podemos depreender que na época de Amós, ao que tudo indica, as pessoas eram proibidas de trabalhar com o comércio no dia de Shabat e na lua nova (o início do mês judaico). Já que a proibição específica de comerciar e mexer com dinheiro no dia de Shabat não aparece no texto escrito da Torá, concluise, portanto, que aqui se trata de um decreto dos sábios da época de Amós (ou anterior), ou seja, uma mitsvá derabanan e uma criação do âmbito da Torá Oral. 
Segundo Harris (1985), Amós era contemporâneo de Oseias e Isaías, tendo atuado como profeta por volta de 750 a.e.c., no reinado de Jeroboão II (786 - 746 a.e.c.). Se supusermos que Amós foi o autor do livro que leva seu próprio nome, este teria sido um dos primeiros livros dos profetas a ser escrito e seria uma evidência de que já por volta do século VIII a.e.c existiam legisladores definindo a lei judaica para além daquela explicitada na Torá Escrita.

Em outras palavras, com as assunções mencionadas, o trecho em questão poderia ser uma evidência de que na época de Amós, portanto, cerca de 900 anos antes da redação da Mishná (redigida por volta de 200 e.c.), já havia eruditos e estudiosos da Torá que usavam seu conhecimento do texto como base para definir a lei religiosa judaica, criando interpretações e comentários sobre a lei.

Trecho similar, que mostra uma interpretação e especificação da lei do Shabat inexistente na Torá Escrita se encontra em Jeremias 17:21-22: “Assim disse o Eterno: Cuidai de vossas almas e não transportai cargas através dos portões de Jerusalém no dia de Shabat. Que nenhuma carga seja retirada de vossas casas neste dia, e que nenhum trabalho seja por vós realizado; santificai o dia de Shabat como ordenei a vossos pais”.

A menção ao dia de Shabat como dia santo em que trabalho não pode ser relizado é, de fato, da Torá. Mas a menção a carregar e transportar cargas é nova e, aparentemente, um decreto estabelecido pelo próprio Jeremias.

Se supusermos, mais uma vez, que Jeremias é o autor do livro que leva seu próprio nome, a obra fica datada como do período da vésperas da destruição do Primeiro Templo de Jerusalém (586 a.e.c.). Assim, ter-se-ia uma evidência dessa vez que já por volta do final do século VI a.e.c. havia decretos orais sendo instituídos sobre o povo a respeito de como cumprir as leis escritas da Torá.

Depois da destruição do Templo, sabe-se que parte do povo judeu foi para o Exílio na Babilônia $^{31}$ e, posteriormente, sob decreto do Rei Ciro, da Pérsia, conseguiram em parte retornar a Israel. Nesse período um dos maiores líderes do povo era Ezrá, o escriba ${ }^{32}$ (circa 450 a.e.c).

O autor do Livro de Neemias, que deve ter conhecido Ezrá, narra a situação de afastamento do povo em relação à religião. Em meio a esse panorama o autor de Neemias afirma que Ezrá, com sua liderança, tentou fazer com que o povo voltasse a seguir a religião, e como parte de seu plano para atingir esse objetivo, Ezrá propôs um acordo que culminou em um pacto

\footnotetext{
${ }^{31}$ Estima-se que na época do exílio havia cerca de 75.000 judeus no Reino de Judá. Segundo as maiores cifras bíblicas, cerca de 20.000 judeus teriam sido exilados, o que representa que no máximo $25 \%$ da população judaica da época foi ao cativeiro babilônico (Finkelstein, I.; Silberman, N. A. (2001). The Bible Unearthed: Archaeology's New Vision of Ancient Israel and the Origin of Its Sacred Texts. Simon and Schuster).

${ }^{32}$ Também chamado pela forma latinizada Esdras, o escriba.
} 
firmado entre o próprio povo, segundo o qual, "se os povos da terra trouxessem mercadorias ou qualquer tipo de víveres para nos vender, não os compraríamos nem no dia de Shabat nem em qualquer outro dia sagrado" (Neemias 10:32).

Mais uma vez é possível ver como por influência de um líder (neste caso, Ezrá) o povo se comprometia a cumprir certas leis e decretos que não estavam explicitamente descritos no texto da Torá, mas que eram fruto de ensinamentos orais.

Segundo Williamson (1987, p. 17) e Barr (2000, p. 87), os relatos do Livro de Neemias supracitados são genuínos e, portanto, foram realmente escritos por Neemias, referindo-se a Ezrá. Sendo assim, não seria exagero algum afirmar que na época de Ezrá e Neemias (circa 450 a.e.c) e, muito provavelmente antes disso (como foi mostrado), já era difundida e aceita a ideia de que a Torá Oral era necessária para entender e cumprir a Torá Escrita; e era necessário que os líderes religiosos e os estudiosos do texto sagrado especificassem o permitido e o proibido no âmbito da lei, pois apenas o texto escrito da Torá não bastava.

Como se pode ver do que foi exposto, existe uma conclusão importante a se tirar: se for verdade que os livros dos profetas foram escritos pelos próprios profetas (e não forem obras pseudepigráficas), isso significa que, em um primeiro momento, a liderança religiosa e o poder com relação ao estabelecimento da lei estava nas mãos dos profetas. Posteriormente, com o encerramento oficial das profecias (circa 313 a.e.c., Cf. San'hedrin ${ }^{33} 11 \mathrm{a}$ ), e em um processo ligado à destruição do Templo, essa função passou para a mão dos que viriam a ser chamados de sábios; pessoas com autoridade religiosa sobre o povo por conta da sua vasta erudição, de sua lógica e argúcia, e por conta do seu conhecimento do texto sagrado e da tradição.

Quanto aos profetas, não sabemos que métodos eram usados para que eles definissem e explicassem a lei, mas quando chegamos à época dos sábios - tanaítas e amoraítas (especialmente esses últimos) - passamos a ter registros escritos de suas discussões e processos hermenêuticos.

2.2.2 A época da Mishná, a primeira obra compilada da Torá Oral

Depois de Ezrá, o próximo grande marco na história da Torá Oral é a compilação da Mishná, levada a cabo pelo Rabi Iehudá Hanassi (140-220 d.e.c).

\footnotetext{
${ }^{33}$ Tratado do Talmud que estuda questões relativas ao Sinédrio (San ’hedrin).
} 
Entre Ezrá e o Rabi Iehudá existe uma lacuna de mais de seis séculos. Do ponto de vista político, este foi um período conturbadíssimo para a Terra de Israel. Houve domínio de diferentes povos - como os persas, os gregos, os egípcios e os sírios. Houve a revolta dos hasmoneus, que trouxe a independência para Judá e estabeleceu um reinado judaico que durou cerca de cem anos. Israel também esteve sob domínio romano, e Herodes a governou. No ano 70 d.e.c Jerusalém foi destruída, e, junto com ela, o Segundo Templo. Não muito tempo depois (em 135 d.e.c), Bar Cochvá se revoltou e tentou expulsar os romanos do país.

Do ponto de vista da Torá Oral, no entanto, todo esse período de Ezrá até a compilação da Mishná pode ser encarado como um período único e de característica uniforme. Os relatos de Ezrá entraram para o cânone bíblico, enquanto que a próxima grande referência literária que temos em mãos hoje, a literatura tanaíta, data apenas do final de um longo período de seis séculos.

Examinar detalhadamente esse período de tempo foge ao objetivo deste trabalho e o mesmo se aplica à própria literatura tanaíta. No entanto é necessária sua menção e breve análise aqui pois ela foi o elemento definidor e possibilitador da literatura do período seguinte, a amoraíta, na qual foi compilado o Talmud, foco deste trabalho.

Como já mencionado, a Mishná é um livro que traz compilações de leis orais levadas a cabo pelo Rabi Iehudá. No entanto, do ponto de vista legal e filológico, essa compilação revela-se problemática, pois é extremamente curta e concisa, e, via de regra, não traz maiores explicações ou citação de fontes. Assim, na Mishná muitas vezes não é possível saber quem é o autor de certa lei, se o próprio Rabi Iehudá ou algum outro sábio. Além disso, mesmo quando a lei é atribuída a alguém, em geral, ela é citada sem que o Rabi Iehudá diga como ele, ou os sábios mencionados no texto, chegaram à conclusão a que chegaram. A impressão que se tem ao ler a Mishná, salvo raras exceções, é de que a lei foi sempre daquele jeito, e se trata de um ponto consensual, que estava meramente sendo registrado por escrito. Portanto, para um trabalho que pretende entender os métodos utilizados pelos sábios para a definição da lei a partir do texto escrito da Torá, a Mishná (junto com a Tossefta ${ }^{34}$ ) é uma obra de pouca valia.

Mesmo assim, se quisermos achar uma resposta para isso dentro do próprio texto da Mishná, visando entender como funciona esse processo legislativo rabínico, uma das poucas referências que poderiam ajudar nesta empreitada é extremamente controversa e um tanto quanto dogmática. No Tratado de Avot da Mishná lê-se o seguinte: “Moisés recebeu a Torá do

\footnotetext{
${ }^{34}$ Adendo ou suplemento. É uma outra compilação da Torá Oral datada mais ou menos da mesma época da Mishná. Cf. nota 27, supra.
} 
Sinai, transmitiu-a a Josué, Josué aos anciãos, os anciãos aos profetas, os profetas aos membros da Grande Assembleia" (Avot 1:1).

Segundo esta visão, a lei era definida de certo modo, e não de outro, por ter sido transmitida oralmente dessa maneira desde Moisés. A afirmação não deixa espaço para discussões, e não explica as razões por trás de cada mandamento. A lei teria nascido "pronta", como produção divina propriamente dita, e teria sido entregue assim a Moisés, que, por sua vez, a teria passado adiante, aos líderes do povo. Assim, nessa visão, quando Ezrá explica ao povo que é proibido comerciar no dia de Shabat, isso não seria uma invenção sua, mas sim uma lei que tinha sido dada a Moisés e ele estava apenas transmitindo, como um elo da cadeia da tradição.

Já tratamos sobre a possibilidade de veracidade dessa questão e vimos que até mesmo alguns textos da tradição dizem que as leis eram criadas e explicadas por sábios muito posteriores a Moisés, que não tinham recebido isso necessariamente de uma fonte tradicional.

Portanto, saber exatamente que métodos os primeiros grupos de sábios (da época da Mishná e anterior a ela) usaram para da Lei Escrita extrair a Lei Oral (que chegou até nós pela Mishná) talvez seja um mistério que jamais resolveremos. O que sabemos apenas, e o que podemos afirmar com certeza, é que os sábios da época da Mishná, e, muito provavelmente, antes dela, preocupavam-se em explicar a Torá e seu texto conciso para formar leis de aplicação prática. Talvez isso remonte à época dos profetas, como já foi mostrado anteriormente.

Na Mishná especificamente - o grande livro haláchico depois da Torá - essas leis foram compiladas pelo Rabi Iehudá Hanassí e são dadas, em geral, de maneira curta e grossa se comparadas com a apresentação talmúdica. Na Mishná muitas vezes as explicações para uma lei são inexistentes ou quando aparecem, são, frequentemente, simples e sucintas. 


\section{DE ONDE VEM A AUTORIDADE RABÍNICA PARA DEFINIR A LEI}

Do que foi discutido até agora, pode-se notar que os sábios do judaísmo se viam no dever de explicar e esclarecer as leis bíblicas. Mas de onde surgiu essa ideia de dever legislativo? Por acaso essa atividade dos sábios tem base na própria ideologia da Torá ou é fruto de um processo social em que esses sábios naturalmente ocuparam a posição de legisladores? Existe algo na Torá, ou fora dela, que justifique a autoridade rabínica para criar leis?

No mundo moderno é comum dividir o sistema jurídico de um país em três partes: executivo, legislativo e judiciário. No mundo antigo, no entanto, essas três formas de poder estavam geralmente concentradas em uma só figura, o rei.

No caso da cultura hebraica, isso não era diferente (cf. 2 Samuel 15:2, 1 Reis 3:1628) e a tradição atribui, por exemplo, ao Rei Salomão alguns decretos religiosos que são seguidos até hoje, como os decretos de eruvin, ${ }^{35}$ de lavagem das mãos antes das refeições e algumas leis ligadas à nudez (Talmud Babilônico [TB], Shabat 14b).

Antes do estabelecimento da monarquia em Israel, no entanto, ainda na época da Mishná e do Talmud (10 a cerca de 500 d.e.c.), os judeus não tinham um governo central na Terra de Israel (CUNDALL, 1973, pp. 33-39 e VAUX, 1997). Alguns autores (KHURT, 1995, p. 438) chegam a afirmar que tal governo central nem sequer existiu na época do período chamado de "Monarquia Unida" (1050 - 930 a.e.c.). Mesmo assim, durante todo o período da dominação romana e bizantina, os judeus desfrutaram de autonomia praticamente irrestrita em assuntos internos, incluindo os de cunho legislativo (Cf. FINKELSTEIN, I.; SILBERMAN, N. A., 2001).

O que se sabe hoje, portanto, é que de modo muito similar ao que ocorria com Salomão na monarquia, os sábios tinham em suas mãos o poder de decretar, julgar e promulgar leis religiosas, a ponto de se popularizar no Talmud o chavão rabanan iqru melachim (os sábios são

\footnotetext{
${ }^{35}$ Plural de eruv (lit. "mistura"). Existem três tipos de eruv, o eruv chatserot ["mistura de pátios"], o eruv tavshilim ["mistura de cozidos"] e o eruv techumim ["mistura de limites"]. De modo geral, o eruv trata da união de vários recintos, públicos e/ou privados, para que se possa carregar objetos entre eles o que, de outro modo, seria ilegal pela Halachá no dia de Shabat.
} 
chamados de reis, Guitin 62a).

Assim, social e politicamente falando os judeus gozavam dessa liberdade legislativa, fornecida pelos governos estrangeiros dominando a Terra de Israel, mas do ponto de vista teológico e da tradição, de onde vinha esse poder atribuído aos sábios?

Já foi visto que a Torá Escrita é a principal fonte da lei e do julgamento no mundo judaico. Assim sendo, como entender que seres humanos também legislem, adicionando, removendo ou até modificando as leis trazidas no texto da Torá?

Essa atividade se fez como fruto da necessidade de explicar e interpretar as palavras escritas na Torá (ALON, 1988, p. 391). Segundo Alon, essa necessidade interpretativa é inerente ao texto bíblico e suas características e, portanto, algo "natural". Por exemplo, há trechos na Torá que não são claros o suficiente para que se defina a lei; e há, por outro lado, passagens genéricas demais, que exigem o cumprimento de um mandamento sem, no entanto, entrar em detalhes sobre como isso deve ser feito. Há, ainda, casos específicos em que uma lei é mencionada usando palavras e termos arcaicos, expressões desconhecidas do grande público, e que, portanto, precisavam de uma explicação para serem compreendidas.

É interessante notar que a necessidade de interpretar um texto que se pretende jurídico se aplica a qualquer tipo de tex to dessa natureza, e em qualquer época, não sendo um fenômeno exclusivo da Torá. Um código de leis jamais é auto-suficiente e auto-explicativo, e sempre exige comentários e interpretações dos juristas e legisladores. É justamente isso que possibilita e viabiliza a existência de julgamentos com a presença de advogados debatendo a aplicação da lei. Se o código legal fosse auto-suficiente, bastaria um juiz para aplicar a sentença, sem a necessidade de julgamentos e deliberações sobre cada caso.

Esta necessidade de interpretar a lei em caso de dúvida é algo sabido e mencionado pela própria Torá, e o motivo que justifica a autoridade rabínica (ALBECK, 1943, p. 89). Sendo assim, o próprio texto bíblico dá as instruções sobre o que precisa ser feito em casos nos quais há dificuldades de julgar um evento baseado somente na lei escrita:

Quando alguma lei te for desconhecida em juízo - se um sangue for puro ou impuro, se uma causa for justa ou injusta, se uma chaga for pura ou impura, ou se surgirem causas que provoquem divergências de opiniões em tuas cidades -, levantar-te-ás e subirás ao lugar que escolher o Eterno, teu Deus. E virás aos sacerdotes-levitas e ao juiz que houver naqueles dias, e indagarás e te anunciarão a sentença do juízo. E farás conforme o mandado da palavra que te anunciarem do lugar que escolher o Eterno, e cuidarás de fazer de acordo com tudo o que te ensinarem. Conforme o mandado da lei que te ensinarem, e conforme o juízo que te disserem, farás; não te desviarás da sentença que te anunciarem nem à direita nem à esquerda. E o homem que o fizer com malícia, para não ouvir o sacerdote que está ali para servir ao Eterno, teu Deus, ou ao juiz - o tal homem morrerá, e eliminarás o mal de Israel. E todo o povo escutará e temerá, e não mais procederão mal. 
(Deuteronômio 17:8-13)

O texto é claro e diz que a autoridade legislativa em caso de dúvida quanto ao texto da lei deve ser dada aos sacerdotes-levitas e ao juiz que houver naqueles dias. São eles os encarregados de explicar as palavras de Torá. Mais do que isso, o texto diz: conforme o mandado da lei que te ensinarem, e conforme o juízo que te disserem, farás. Ou seja, o próprio texto bíblico define essas figuras como as que tinham a autoridade para criar leis e impor a sua execução sobre a comunidade. Esses eram os detentores da lei. ${ }^{36}$

No entanto, a rigor, esse versículo só poderia ser seguido à risca na época em que o Templo de Jerusalém existia, pois havia, então, a manutenção da classe sacerdotal e levítica. Porém, como já mencionado, na época de Ezrá, o escriba, começou a haver uma profunda transformação no cenário hebraico antigo, já que o Templo foi destruído e a figura dos sacerdotes-levitas passa a ficar em segundo plano. É justamente nesse período que a função de explicar e decretar a lei passa para a mão dos sábios. Com a progressiva perda de importância da classe sacerdotal-levítica, a autoridade e o poder para definir a lei e julgar o povo segundo ela se concentrou na mão dos eruditos, aqueles que devotavam a maior parte do seu tempo a estudar do texto sagrado.

A partir desse momento, os versículos extraídos de Deuteronômio passam a ser entendidos como uma fonte que legitimava a autoridade legal dos sábios da época. Embora não haja referência direta aos "estudiosos" ou "eruditos" no texto da Torá, a partir desse momento são eles que se tornam o juiz que houver naqueles dias.

No poder que se concentrou na mão dos sábios estavam inclusas duas coisas:

1) A autoridade de explicar como cumprir um mandamento - explicar trechos e passagens bíblicas segundo os métodos de interpretação da Torá (vide adiante).

2) A autoridade para determinar a lei e dirimir dúvidas legais - também esta uma atividade baseada na interpretação de trechos da Torá.

Como se pode ver, ambas as facetas da autoridade rabínica dependem da interpretação dos textos (tópico que será abordado com mais detalhes no capítulo 5), um processo que é, por natureza, subjetivo. Assim, com o passar do tempo, nada mais natural do que o surgimento de

\footnotetext{
${ }^{36}$ Para mais indicações sobre isso, cf. Jeremias 2:8, 18:18; Ezequiel 7:26, Malaquias 2:7; 2 Crônicas 17:7-9.
} 
várias disputas e divergências entre os sábios sobre como definir e aplicar a lei (sobre as disputas quanto aos métodos de interpretação, cf. capítulo 6), divergências essas que são a própria essência de textos como o Talmud.

No entanto é interessante notar que, segundo alguns sábios, provavelmente em uma visão utópica e idílica da coisa, nem sempre essa divergência existiu:

\begin{abstract}
O Rabi Iossi disse: no começo não havia divergências em Israel, pois havia o Tribunal de setenta e um membros que se reunia no pátio do Templo... de lá saía a lei e era espalhada por Israel. Desde que se multiplicaram os alunos de Shamai e de Hilel e que não serviam a nenhuma necessidade, se multiplicaram as divergências em Israel, e duas Torot foram feitas.
\end{abstract}

(Tossefta, Chaguigá 2:9)

É importante ressaltar que embora a visão do Rabi Iossi pareça ser particularmente negativa e crítica com relação às divergências, vários sábios não deixaram de considerar importante o fenômeno da existência das disputas, preocupando-se até mesmo em registrar nos textos legislativos as ideias das minorias, mesmo quando não eram aceitas pelos outros sábios:

\begin{abstract}
A lei é sempre conforme a palavra da maioria. As opiniões individuais foram registradas em meio às opiniões da maioria apenas para serem canceladas. O Rabi Iehudá diz: As opiniões individuais foram registradas em meio às opiniões da maioria porque elas podem ser necessárias em algum momento e então será possível se apoiar nelas. Os outros sábios dizem: As opiniões individuais foram registradas em meio às opiniões da maioria apenas para constar que este disse que é puro e aquele disse que é impuro; este diz que algo é impuro baseado no Rabi Eliezer e os outros dizem a ele que as palavras do Rabi Eliezer o tornam puro.
\end{abstract}

(Tossefta, Eduiot 1:4)

\title{
3.1. A resolução das disputas
}

Já vimos que como a definição da lei passa por métodos interpretativos - e, portanto, subjetivos - do texto bíblico, acabaram surgindo divergências no entendimento do texto, o que acarretava, por consequência, uma diferença no estabelecimento da lei. Quando isso ocorria, os sábios se viam na obrigação de resolver a divergência e optar por uma das ideias, definindo, assim, a lei a ser cumprida.

A rigor, e na teoria, não deveria haver qualquer dificuldade por parte dos sábios para resolver disputas do tipo, pois já desde muito cedo eles convencionaram (ou entenderam) que 
em casos de divergência a opinião que vale é a da maioria. ${ }^{37}$

No entanto, na prática, muitas vezes vemos nos textos que mostram divergências de opiniões entre os sábios que não é estritamente a visão da maioria que conta e que a definição da lei passa por muitas outras questões.

Por exemplo, os sábios se preocupavam em se certificar de que a ideia a ser aprovada se baseava na tradição, e de que não era mero fruto especulativo de uma geração. Outra preocupação era se certificar de que a ideia a ser aprovada, mesmo vinda de uma maioria, estava baseada em pessoas realmente grandes em Torá, pessoas com conhecimento da lei e do texto sagrado, e que não fossem pessoas de caráter duvidoso ou conhecimento insuficiente do texto sagrado.

Exemplos disso podem ser vistos na Tossefta do tratado de San'hedrin, onde aparecem máximas como as seguintes:

1 - não julgamos a não ser que (o sábio) seja grande, e não julgamos a não ser quando aquilo foi ouvido (da tradição) (San ’hedrin 7:2).

2 - se um sábio diz que ele ouviu aquilo (da tradição) e todos os outros dizem que não ouviram aquilo, neste caso não se vai atrás da maioria (idem).

3 - um proíbe e outro permite; um impurifica e outro purifica; e todos dizem que não ouviram nada sobre aquilo, a maioria prevalece (idem).

\subsection{Definição da lei}

Assim, além do princípio geral de que a lei deve ser definida conforme a maioria, existiam outros princípios básicos que pautavam a atividade legislativa rabínica. Desses princípios há alguns especialmente dignos de nota.

3.2.1. Casos de "a Torá não está nos céus"

\footnotetext{
${ }^{37}$ Vide Chulin 11a. Chulin significa "coisas ordinárias e mundanas". É um tratado do Talmud que lida basicamente com as leis de abate e consumo de carne (de animais "ordinários", por oposição aos animais oferecidos como sacrifício).
} 
De modo geral, os sábios entenderam que a lei religiosa não podia ser definida por profetas ou pela profecia. Por consequência, ao longo do Talmud vemos que poucas vezes os sábios tentam definir a halachá se baseando em algum evento extraordinário ou transcendental; e, em geral, quando isso ocorre, a opinião do Sábio que recorre a esse tipo de "argumento" não é aceita.

Uma das histórias mais famosas sobre isso envolve o Rabi Eliezer ben Hircanos e está narrada no Tratado de Bava Metsia ${ }^{38}$ 59a-b.

\begin{abstract}
Nós aprendemos em outro local: se a pessoa o cortou em partes separadas e colocou areia entre cada uma das partes, o Rabi Eliezer o declara puro, e os sábios o declaram impuro, e esse era o forno de Acnai. Por que forno de Acnai? O Rabi Iehudá disse em nome de Samuel: Ele era chamado assim porque ele foi cercado de argumentos como uma cobra, e provou que era impuro. Foi ensinado: Naquele dia o Rabi Eliezer trouxe todos os argumentos possíveis e imagináveis, mas os outros não os aceitaram. Ele disse para eles: Se a halachá é como eu digo, que esta alfarrobeira sirva de testemunho! Imediatamente a alfarrobeira foi desarraigada e levada para cem cúbitos mais longe de onde estava - outros dizem que foi quatrocentos cúbitos. "Não se pode extrair provas de uma alfarrobeira", eles disseram. Ele voltou a dizer: Se a halachá é como eu digo, que esse córrego sirva de testemunho! Imeditamente o córrego passou a correr para trás, no sentido inverso. "Não se pode extrair provas de um córrego", os outros retrucaram. Ele voltou a clamar: Se a halachá é como eu digo, que as paredes desta escola sirvam de testemunho! Imediatamente as paredes se inclinaram e ameaçaram cair. Mas o Rabi Iehoshua as reprovou dizendo: Se estudiosos estão discutindo a halachá, que direito vocês têm de intervir? Então elas não caíram, em honra ao Rabi Iehoshua; mas também não ficaram retas, em honra ao Rabi Eliezer, e elas estão até hoje inclinadas. Ele voltou a dizer: Se a halachá é como eu digo, que os Céus o provem! No mesmo instante uma voz celestial se fez ouvir e disse: Por que vocês debatem com o Rabi Eliezer vendo que em todos os assuntos a halachá é como ele diz? Mas o Rabi Iehoshua se levantou e exclamou: ela não está nos céus! O que ele quis dizer com isso? - o Rabi Ieremiah disse: que a Torá já tinha sido dada no Monte Sinai e que não devemos dar ouvidos à uma voz celestial, pois há muito tempo foi escrito na Torá dada no Sinai: inclina-te à maioria (Êxodo 23:2). O Rabi Natan encontrou com Elias e perguntou para ele: O que o Santíssimo, bendito seja, fez naquele momento? - Ele sorriu e disse: "Meus filhos Me venceram, Meus filhos Me venceram!". Foi dito que naquele dia todos os objetos que o Rabi Eliezer tinha declarado puros foram trazidos e queimados no fogo.
\end{abstract}

(Bava Metsia 59a-b)

No trecho vemos que no ápice das provas sobrenaturais, trazidas pelo Rabi Eliezer, uma voz celestial surge e diz especificamente que a lei é sempre conforme esse sábio. Mesmo assim, a voz é desconsiderada pelos outros sábios, e a lei acaba sendo estabelecida conforme a maioria.

${ }^{38}$ Lit. "Parte Central". É o segundo tratado dos três primeiros que compõe a ordem de Nezikin (Danos). Os outros dois são Bava Qama (Parte Inicial) e Bava Batra (Parte Final). Cada um dos tratados se debruça sobre as leis de danos e dolos, e o Bava Metsia especificiamente trata de danos à propriedade e das leis de usura. 
Em hebraico, essa "voz celestial” é chamada de bat col (Cf. LIEBERMAN, 1984, pp. 294-297) e existe um trecho no Talmud em que é ela que define um princípio de halachá importante e que, excepcionalmente, é aceito pelos sábios:

O Rabi Aba disse em nome de Shemuel: por três anos a Escola de Shamai discutia com a Escola de Hilel, cada uma dizendo que a halachá era conforme a sua opinião. Surgiu uma voz celestial e disse: ambas são as palavras do Deus vivo, e a halachá é conforme a Escola de Hilel.

$(\text { Eruvin } 13 b)^{39}$

Muitos comentaristas posteriores se viram na obrigação de se debruçar sobre esse último trecho talmúdico para tentar explicá-lo e eliminar a polêmica de como pode ser que a lei tenha sido definida por uma "voz celestial". ${ }^{40}$

3.2.2. A diferença do estudo da Torá e da lei promulgada no tribunal

Lendo o Talmud é fácil perceber que muitos dos Sábios ali mencionados tinham duas funções principais: atuavam como professores nas casas de estudo e nas ieshivot ${ }^{41}$ e também como juízes nos tribunais judaicos da época.

Essa dupla atividade muitas vezes levou os sábios a terem muito cuidado na hora de definir certas leis baseados em relatos de vida de outros sábios, pois muitas vezes não ficava claro para eles se estavam diante de um decreto de tribunal dado por um sábio (e que era, portanto, a lei que deveria ser efetivamente cumprida), ou se a opinião diante deles era uma mera especulação ideológica entre um professor e seus alunos, ou entre um sábio e outro sábio (algo circunscrito ao ambiente educacional e com meros fins pedagógicos).

Sendo assim, existe um outro princípio importante no Talmud no que diz respeito à definição da lei: Nossos mestres ensinaram: a halachá não pode ser estabelecida com base em uma conclusão teórica nem com base em uma decisão prática a não ser que tenha sido dito explicitamente que a halachá serve para decisões práticas (Bava Batra 130b) ${ }^{42}$.

\footnotetext{
${ }^{39}$ Literalmente "mistura". Cf. supra n. 35.

${ }^{40}$ Os interessados podem ver a interpretação e análise crítica dessa passagem feita por Itschac Engelder no Anuário “Hamishpat Haivri”, volume 1, organizado por Menachem Alon e Chaim Cohen (Jerusalém), 1974, pp. 45-56.

${ }^{41}$ Instituição de ensino judaica, com foco nos textos da tradição, como Torá e Talmud. A maioria das ieshivot tem por objetivo formar rabinos atuantes na comunidade local.

${ }^{42}$ Lit. "Parte Final". Cf. supra, n. 38.
} 


\subsubsection{Diferenças entre tribunais}

Mesmo quando se sabia que a lei tinha sido definida por um Sábio dentro do tribunal, e não em um ambiente pedagógico, outra questão se colocava como problemática: a existência de diferentes tribunais judaicos. Os sábios prezavam a opinião da maioria, como já foi dito, mas às vezes para decidir a lei eles tinham relatos discordantes de dois tribunais igualmente grandes e famosos. Assim, garantia-se que os casos em questão eram práticos e não mera especulação teórica, como pede o princípio anterior, mas a decisão da maioria dos sábios em um tribunal foi A e em outro, que também obteve uma maioria, a decisão foi B. Então o que fazer quando "duas maiorias" diferiam quanto à aplicação da lei com respeito a um mesmo caso?

Em tais casos, os sábios aplicavam o que ficou conhecido como princípio do "maior em número e sabedoria" (ALBECK, 1999, p. 71). Esse princípio afirma que não bastava apenas uma maioridade numérica para definir a lei como a maioria, mas também a certeza de que existia uma maioridade no sentido intelectual.

Assim, se dois tribunais compostos, digamos, de dez sábios, divergissem quanto à aplicação da lei; na hora de definir qual das leis seguir, o número não seria levado em consideração (obviamente), mas apenas a maioria no que diz respeito à erudição e conhecimento da Torá.

\subsection{Diferenciação de leis da Torá e dos Rabinos}

Independentemente da autoridade dos sábios para definir, interpretar e legislar segundo as leis escritas na Torá, e independente dos princípios gerais mencionados que eram seguidos por eles nesta tarefa, sempre foi uma importante questão jurídica, até mesmo para estes mesmos sábios, diferenciar o que é uma lei diretamente da Torá (chamada, em aramaico, deoraita) e o que é uma lei definida por um sábio ou por um Tribunal Rabínico (chamada, em aramaico, derabanan).

Segundo a visão da tradição, do ponto de vista legal e da aplicação jurídica, ambos os tipos de lei devem ser cumpridos e têm a mesma obrigatoriedade. No entanto, existem algumas 
diferenças com relação às consequências derivadas de cada grupo de leis, e é isso que preocupava os sábios e os motivava a fazer diferenciações do tipo em livros como o Talmud.

\subsubsection{Características gerais e relevância}

$\mathrm{Na}$ Torá vemos escrito o seguinte: E tomareis para vós, no primeiro dia, o fruto da árvore formosa, palmas de palmeira, ramos de murta e de salgueiro de ribeiras, e vos alegrareis diante do Eterno, vosso Deus, por sete dias (Levítico 23:40).

Aqui há um mandamento de se unir as quatro espécies mencionadas em ritual feito no primeiro dia da festa de Sucôt. No entanto, a Mishná (Sucá 3:12 e Rosh Hashaná 4:3) vem e diz:

No começo as palmas de palmeira eram usadas no Templo por sete dias, e em todo o resto do país por um dia. Desde que o Templo foi destruído, o Rabi Iochanan ben Zacai decretou que as palmas de palmeira deviam ser usadas em todo país por sete dias, em lembrança ao Templo.

Do texto da Mishná fica claro que o mandamento de usar as quatro espécies durante sete dias (que é a prática até hoje) é um decreto rabínico, instituído pelo Rabi Iochanan ben Zacai, e não uma lei da Torá. Sendo assim, no primeiro dia da festa, o mandamento de usar as quatro espécies é da Torá e nos outros dias o mandamento é rabínico. Esse fato gerou uma discussão entre sábios amoraítas:

\footnotetext{
O Rabi Iochanan, no primeiro dia da festa, profere a bênção "Bendito és Tú, ó Eterno, nosso Deus, Rei do Universo, que nos santificaste com os Teus mandamentos e nos ordenaste cumprir o mandamento das palmas de palmeira"; e nos outros dias ele diz: “os mandamentos dos anciãos”. O Rabi Iehoshua abençoa todos os dias dizendo: “o mandamento das palmas de palmeira". Por acaso o Rabi Iehoshua não reconhece o mesmo que o Rabi Iochanan, que o primeiro dia festivo é da Torá - pois está dito "E tomareis para vós, no primeiro dia etc.” - e que os outros dias são palavras deles [dos sábios]? O Rabi Shimon bar Chalafta disse em nome do Rabi Acha: o Rabi Iehoshua sabia disso. Então por que ele fazia o que fazia? Porque está escrito "Como aguilhões são as palavras dos sábios; como pregos bem fixados, os dizeres dos mestres; como sentenças agrupadas que têm uma mesma origem" (Eclesiastes 12:11). As palavras de Torá e as palavras dos sábios têm uma mesma origem.
}

(Bamidbar Rabá 14:4)

O princípio trazido pelo Rabi Shimon bar Chalafta acima (as palavras de Torá e as palavras dos sábios têm uma mesma origem) é o aceito hoje em dia e, assim, a lei judaica atual 
diz que não importa se um mandamento é da Torá ou dos sábios, a bênção que se faz é sempre a mesma, já que se pode considerar que mesmo o que os sábios ordenaram tem a mesma origem do que está ordenado diretamente na Torá.

Mesmo assim é interessante ver que nesse trecho específico existe uma divergência quanto à bênção que se pronunciava, por conta de o mandamento ser rabínico ou da Torá, e daí se vê um exemplo da importância de diferenciação dos casos. Isso levou alguns acadêmicos modernos a duvidar do princípio tradicional que afirma que leis deoraita e derabanan têm o mesmo peso, como Hirvonen (2001), que afirma: “Assim, esses mandamentos que vêm diretamente da Torá (deoraita) e que são bíblicos são uma autoridade superior aos mandamentos rabínicos (derabanan), que não vêm dela".

De fato, a hipótese acadêmica parece acertada. Embora no trecho citado, por exemplo, a conclusão final seja de que ambos os mandamentos têm a mesma origem (leia-se: divina) e, portanto, a mesma bênção deve ser feita em todos os dias da festa de Sucôt, existem casos em que os sábios não viram os dois tipos de mandamentos em pé de igualdade, mas antes notaram existir diferenças práticas e de peso entre cada tipo de lei.

3.3.2. Diferenças práticas entre as duas classes de mandamentos

3.3.2.1. No que é da Torá vai-se atrás do mais severo, no que é dos escribas vaise atrás do mais leniente

No caso de divergência sobre uma questão legal, o Talmud estabelece um princípio:

Nossos sábios ensinaram... se a opinião deles é divergente, um considera impuro e o outro considera puro, um proíbe e o outro permite... O Rabi Iehoshua ben Carcha diz: se a questão for uma lei da Torá, vai-se atrás do mais severo; se for uma lei dos escribas, vai-se atrás do mais leniente. O Rabi Iossef disse: A halachá é conforme o Rabi Iehoshua ben Carcha

(Avodá Zará $7 \mathrm{a})^{43}$

\footnotetext{
${ }^{43}$ Lit. "idolatria". Tratado talmúdico que versa basicamente sobre leis que se aplicam a judeus vivendo entre gentios e a interação entre ambos, com o objetivo principal de evitar a idolatria judaica ou a assimilação com outras culturas.
} 
Em outro ponto do Talmud esse princípio é resumido assim: toda dúvida de Torá resolve-se com a severidade... e toda dúvida dos sábios resolve-se com a leniência (Betsá 3b). ${ }^{44}$

Por exemplo, no caso trazido anteriormente, a respeito da necessidade de fazer uma bênção sobre as quatro espécies em Sucót, vamos supor que uma pessoa se esqueceu de fazer a bênção no primeiro dia (um mandamento da Torá). A maioria dos rabinos diria que, para evitar incorrer em erro, ela deve recitar a bênção novamente, para se assegurar de que o mandamento da Torá será cumprido. No entanto, se a bênção dos dias posteriores fosse esquecida pela pessoa, alguns sábios argumentariam que ela não precisa se preocupar em repetir a oração (por ser um mandamento dos sábios que, se não cumprido, não acarreta em descumprimento direto e explícito da Torá).

\subsubsection{Impedimento de cumprir os mandamentos da Torá}

Apesar de os regulamentos rabínicos serem considerados de maneira mais leniente quando comparados aos mandamentos da Torá, curiosamente há casos em que os sábios se viram com autoridade suficiente para proibir que as pessoas cumprissem os mandamentos explícitos do texto da Torá. Em outras palavras, eles viam como legítimo que um mandamento derabanan se sobrepusesse a e revogasse um mandamento deoraita. ${ }^{45}$

Um exemplo pode ser visto no fato de que a Torá ordena que se toque o shofar ${ }^{46}$ no Rosh Hashaná, ${ }^{47}$ mesmo quando se trate de um dia Shabat. No entanto, os sábios se manifestaram e, por medo de profanação do dia de Shabat (por exemplo, temendo que a pessoa carregasse o instrumento de um recinto público para um privado ou vice-versa), decretaram que era proibido tocar o shofar no Rosh Hashaná que cai no dia de Shabat.

Guilat (1958) defende que o poder e autoridade dos sábios eram maiores e mais fortes nas primeiras gerações do surgimento do judaísmo rabínico, mas, com o tempo, essa autoridade foi sendo reduzida.

Seja como for, mesmo na época do Talmud os sábios se preocupavam com a questão, e tentavam entender e delimitar qual era o poder e a autoridade que eles mesmo tinham frente

\footnotetext{
${ }^{44}$ Lit. "ovo". Tratado talmúdico sobre as leis dos festivais judaicos. O tratado recebe esse nome por ser essa a palavra inicial do texto.

${ }^{45}$ Existem diversos exemplos de casos assim na Enciclopédia Talmúdica, v. 10, pp. 97-99.

${ }^{46}$ Instrumento ritual de sopro feito, em geral, de chifre de carneiro.

${ }^{47}$ Ano novo judaico.
} 
aos mandamentos da Torá. Assim, esse grande poder legislativo dos sábios foi alvo de muita discussão entre eles. Das folhas 89 a até $90 \mathrm{~b}$ do Tratado de Ievamot $^{48}$ os sábios do Talmud discutem longamente sobre a validade dessa prática e em que casos e circunstâncias eles podiam usar de sua autoridade pessoal para anular um decreto da Torá.

Ao final da discussão, os sábios concluem que essa sua autoridade só é válida se pautada por três princípios:

1 - shev ve al taassê - os sábios podem ordernar que um mandamento da Torá deixe de ser feito se com o não-fazer do mandamento não for cometida uma transgressão (o violar de um mandamento proibitivo da Torá).

2 - im iesh bedavar memeigader milta... acrinan lo taassê mamash beiadim - quando por conta de suas leis os sábios da Mishná obrigam os sábios do Talmud a instituir leis que sirvam como uma "proteção" para evitar a violação e descumprimento dos mandamentos, estes mesmos sábios têm o poder suficiente para mudar até mesmo um mandamento do tipo "não faça" da Torá, permitindo que o povo transgrida aquela lei. Em outras palavras e, resumidamente, os sábios podem decretar que o povo transgrida um mandamento da Torá se isso for feito com o intuito de evitar a violação e o descumprimento de outros mandamentos.

3 - hefqer beit din hefqer - em assuntos financeiros os sábios são a autoridade máxima e podem emitir decretos e leis que mudem (ou revoguem) totalmente o sentido do que está na Torá, não importando se se trata de um mandamento proibitivo ou permissivo. Pela Torá, por exemplo, há vários casos em que uma herança é de direito da viúva. Mas se na prática jurídica de um tribuanl os sábios decretassem que a herança é do irmão do falecido, por exemplo, a palavra dos sábios é a que vale, em detrimento da opinião da Torá. Vale ressaltar que, para Alon (1988, pp. 417-421), esse é um dos princípios legais que mais permitiu aos sábios criar suas leis e decretos, por causa de sua vastidão, "tanto no sentido de sua autoridade máxima, como no âmbitos dos assuntos por ele englobados", afetando áreas da legislação como "aquisição, dívidas, pagamento de danos, heranças e testamentos".

\subsubsection{As punições de leis rabínicas}

\footnotetext{
${ }^{48}$ Lit. "casamento por levirato". Tratado talmúdico que versa basicamente sobre a lei que obriga a viúva a se casar com seu cunhado, conforme decretado em Deuteronômio 25:5-10.
} 
A questão das punições com relação às leis da Torá e às leis rabínicas é um assunto à parte dentro desta importante diferenciação de leis. Segundo a Torá, quem transgride um de seus mandamentos deve sofrer uma das quatro punições: morte pelo tribunal, excomunhão, morte pelos Céus ou chibatadas.

No entanto os sábios também definiram castigos para os que violam os mandamentos rabínicos, ou seja, para pessoas que não cumprem os mandamentos enunciados por eles, mesmo que eles não estejam escritos na Torá.

O Rabi Eliezer ben Iaacov disse: eu ouvi que o tribunal pode açoitar e condenar à morte mesmo que não se trate de uma transgressão da Torá e (se o objetivo for) para que não se transgrida nada da Torá, mas (apenas se for) para fazer uma proteção à Torá (Ievamot $90 \mathrm{~b}$ e San'hedrin 46a).

Logo depois de mencionar a ideia do Rabi Eliezer, o Talmud traz um relato: Certa vez um homem andou a cavalo no Shabat na época dos gregos, ele foi trazido ao tribunal e enforcado - não porque ele merecia isso, mas porque o momento exigia isso (Ievamot 90b).

Embora haja relatos de pena de morte aplicada pelos sábios e pelo Tribunal Rabínico, tanto do ponto de vista da tradição como da academia moderna, a aplicação desse tipo de pena era rara (Cf. Macot $^{49}$ 1:10 e BERKOWITZ, 2006). Na maioria dos casos os sábios viam as punições como "medidas corretivas", e, portanto, elas não envolviam necessariamente a morte. Como tal, o mais comum era a aplicação de chibatadas, ou, em casos mais graves, o decreto de excomunhão e ostracismo.

Interessante notar que para diferenciar o caso de chibatadas como punição da Torá e o caso de chibatadas decretadas pelos sábios (dada a importância de distinguir o deoraita do derabanan), a esta última punição se deu o nome de macat mardut (medida corretiva). No caso das punições da Torá sempre deveriam ser aplicadas 39 chibatadas. Já no caso das medidas corretivas rabínicas não havia um número fixo pré-estabelecido, e os sábios definiam a punição caso a caso (Cf. Deut. 25:2-4, Ievamot 52a e Lieberman (Ed.), pp. 170-171). ${ }^{50}$

Outra discussão derivada e relacionada a essa é que, a rigor, pela Torá, as punições só se aplicam a quem transgrediu mandamentos negativos, do tipo "não faça", como, por exemplo, "não matarás" ou "não roubarás". Mas a pessoa que deixou de fazer um mandamento do tipo "faça" não era punida. Assim, o texto bíblico ordena: "sentarás na sucá". Se a pessoa, por

\footnotetext{
${ }^{49}$ Lit. "castigos". Tratado mishnaico (com seu paralelo no Talmud) que versa basicamente sobre as leis das cortes rabínicas e os castigos que elas podem administrar à população, em especial as chibatadas.

${ }^{50}$ Pela Torá, o número correto de chibatadas a serem aplicadas, na verdade, é de 40. Para aplicações e explicações sobre a mudança de valor para 39, cf. Macot 3 e Mishnê Torá (Juízes, leis do Sinédrio, cap. 18-19).
} 
qualquer motivo, não fizesse isso durante a festa de Sucot, ela não era punida.

No entanto os sábios "estenderam" o conceito de castigo e punição e definiram que, em casos específicos, mesmo os que deixaram de cumprir um mandamento do tipo "faça" podiam ser punidos por eles: é um lembrete do tribunal para que a pessoa faça aquilo... isso ensina que se deve compeli-lo a fazer... até que ponto? Ele deve ser compelido até que diga 'eu quero fazer' (Ketuvot 86a-b). 


\title{
4 CRIAÇÕES RABÍNICAS NO ÂMBITO DA LEI - TAQANOT, GUEZEROT, ETC.
}

\author{
4.1. Definições
}

Com o que foi exposto até aqui fica claro que algumas leis religiosas seguidas hoje pelo judaísmo não são da Torá e nem tampouco foram dadas diretamente a Moisés no Sinai (como afirma a tradição); mas, antes, são fruto da criação dos sábios tanaítas e/ou amoraítas. No capítulo anterior foi vista a preocupação que os sábios tinham em diferenciar os dois tipos de leis e as consequências diretas dessa diferenciação.

Neste capítulo vamos detalhar mais as criações legais rabínicas, assinalando uma importante diferenciação entre os tipos de leis promulgadas pelos sábios no que diz respeito a seu caráter jurídico.

\subsubsection{Taqaná}

O primeiro tipo de "decreto" rabínico se chama, em hebraico, taqaná. Segundo o dicionário de Ben Iehudá (1989), a taqaná é: uma lei ou um costume que os sábios estabeleceram para o bem e para o benefício do indivíduo ou da comunidade. Já para o dicionário Even-Shoshan, a taqaná é uma lei para o bem do público, reforma.

De modo geral pode-se dizer, portanto, que a taqaná instrui sobre uma ação específica que se deve fazer, e não envolve proibições ou restrições. Pode-se dizer que a taqaná vem para preencher uma lacuna na lei, ou reparar um ponto que não foi definido jurisprudicialmente pela Torá. A Enciclopédia Judaica afirma que taqaná é “um decreto que (1) revisita um mandamento que não mais satisfaz as exigências do momento ou das circunstâncias”. Um exemplo de taqaná é de que as comunidades deviam enviar mensageiros em vez de seguir o antigo costume de acender fogueiras para anunciar o início da Lua Nova (Rosh Hashaná 2:2), pois sabendo do 
método usado pelo povo, alguns inimigos passaram a acender as fogueiras propositalmente em dias errados, para confundir a contagem do mês.

\subsubsection{Guezerá}

A palavra guezerá, ao contrário de taqaná, aparece no texto bíblico. A primeira ocorrência do vocábulo está em Levítico 16:22: E o cabrito levará sobre si todas as suas iniqüidades à terra inabitada (guezerá), e deixará ir o cabrito pelo deserto. Embora aqui o significado seja de terra "erma" ou "isolada", em outro livro do cânone bíblico o termo aparece no sentido de "lei": Isto virá realmente a acontecer porque é um decreto (guezerá) dos anjos (Daniel 4:14).

$\mathrm{Na}$ literatura rabínica, mais especificamente, a palavra passou a significar algo como "decreto", “decisão do tribunal”, "julgamento ou sentença proferida”. A Enciclopédia Talmúdica define com mais exatidão: (guezerá) é uma proibição dos sábios a respeito de algo permitido pela lei, com o intuito de fazer uma cerca e uma proteção. De modo similar, a Enciclopédia judaica afirma que a guezerá é "um decreto rabínico emitido como medida preventiva ou de guarda; também uma proibição ou restrição genérica. O termo está particularmente ligado a uma ordem negativa (taqaná sendo sua contraparte positiva)".

De fato, o que se vê é que a palavra guezerá está sempre ligada à instauração de uma proibição que, pelo texto da Torá propriamente dito não seria algo proibido. Além disso, a guezerá é uma proibição que não se justifica por si mesma, mas só tem fundamento quando encarada como um meio de evitar uma transgressão possível no futuro. Por isso a Enciclopédia Judaica a define como uma "medida preventiva". Ou seja, o ato proibido por uma guezerá não tem nada de reprovável em si mesmo ou por si só e não é considerado um pecado; a única razão para que ele seja proibido é o medo dos sábios de que se aquele ato for praticado com outro ato ele possa ser a base ou o pretexto para transgredir algo que é explicitamente proibido na Torá. Esse é o significado de "fazer uma cerca e uma proteção" mencionado pela Enciclopédia Talmúdica.

No Talmud, a guezerá é introduzida, em geral, por uma das duas expressões: shema (para que não) ou guezerá shema (um decreto para que não). De Vries (1966) chama a atenção para o fato de que sempre que a expressão guezerá shema ocorre no Talmud trata-se de um decreto amoraíta, e jamais tanaíta, pois o termo nunca aparece na Mishná. Na Mishná existem 
ocorrências apenas do termo shema (para que não).

Dois exemplos de guezerá podem ser vistos no Tratado Shabat: um alfaiate não deve sair com a agulha perto do anoitecer (da sexta-feira) para que não (shema) esqueça e saia (Shabat 1:3) e também: não se deve ler à luz de velas, para que não se mexa nela (Shabat 12b).

Em ambos os casos o alvo da proibição em si não é algo passível de ser proibido. Não há problema algum em sair com uma agulha perto do anoitecer de sexta-feira, e nem tampouco ler à luz de uma vela no dia de Shabat (desde que a vela esteja acesa desde antes do anoitecer). Mas os sábios decretam que isso não deve ser feito para que a pessoa não esqueça que está com uma agulha na mão, ou com uma vela acesa, e assim transgrida o dia de Shabat; no primeiro caso, carregando um objeto de um recinto público para um privado (ou o oposto), e, no segundo caso, mexendo a vela.

Com o que foi explicitado anteriormente, pode-se dizer, de forma geral, que uma taqaná é ligada a algo que se deve fazer, e a guezerá a algo que não se deve fazer. Mas é importante ressaltar que não deixa de haver casos em que os sábios do Talmud usam os termos de maneira trocada, sem a uniformidade que estamos apresentando neste trabalho.

Um bom resumo do assunto foi feito por Alon:

Podemos, de fato, concluir e dizer que, de maneira geral, os decretos limitados pelo
termo guezerá incluem instruções que vêm para proibir e impedir a execução de uma
ação específica, que pela lei poderia ser feita. O objetivo nesse caso é o de fazer uma
cerca de proteção a uma proibição determinada na Torá. E, por outro lado, as
instruções limitadas pelo termo taqaná vêm, em geral, ordenar a obrigação de executar
uma ação específica, com o objetivo de trazer um benefício ou estabelecer um reparo
no domínio comunitário ou particular. Esse é o princípio geral, que se aplica na
maioria dos casos, mas não sempre. (M. Alon, Hamishpat Haivri, v. 1, p. 403)

\subsubsection{Minhag}

Pode-se dizer que o Minhag - costume - é uma terceira categoria de jurisprudência rabínica; mas com suas características particulares se comparada à categoria da taqaná e da guezerá.

O dicionário Even-Shoshan define Minhag como: modo de comportamento aceito entre os judeus de uma comunidade dentre as diversas comunidades de Israel, que, no entanto, não está explícito na Torá ou nas palavras dos sábios e tampouco está definido como lei. Um 
exemplo disso são os costumes da véspera do Iom Kipúr.

Para a Enciclopédia Judaica, o minhag é um "antigo e velho costume, ou prática religiosa, sem base em uma passagem específica da Bíblia, e que, pela força do longo período de observação, tornou-se tão sagrado e obrigatório como as leis instituidas pelas próprias autoridades".

Em diversos locais onde a lei está sendo discutida o Talmud traz uma expressão como cach haMinhag (assim é o costume). Quando isso ocorre, o leitor precisa averiguar se a intenção é dizer que esta é de fato a halachá, se a intenção é dizer que uma taqaná ou guezerá rabínica não foi aceita pelo povo, ou, ainda, se a intenção é dizer que em um local específico os judeus seguem aquele costume em oposição à halachá.

A diferença fundamental entre uma guezerá ou taqaná e um Minhag é que os dois primeiros são decretos que surgem dos sábios, ou da instituição jurídica, e chegam ao povo. $\mathrm{O}$ Minhag, ao contrário, tem origem no povo e chega aos sábios, entrando em sua discussão sobre o assunto: às vezes apenas para ilustrar algum ponto, e às vezes para fazer com que a lei realmente seja determinada segundo o costume popular (Cf. ALON, 1988, pp. 713-714). E nisso temos uma das singularidades do Minhag, em que a lei era definida pelo que o povo fazia, e não necessariamente pelo que os sábios consideravam que era o correto segundo seus métodos interpretativos.

É assim que se explica o uso de expressões muito comuns no Talmud, como, por exemplo, poc chazê mai ama davar (saía e veja o que o povo faz) ou tsê ureê ma hatsibur noheg unahug (saia e veja o que a comunidade costuma fazer e a que ela está acostumada).

4.2. Autoridade dos sábios para decretar taqanot, guezerot e minhaguim

No capítulo 3 já vimos de onde os sábios entenderam que tinham o dever de interpretar e explicar a Torá depois que essa função deixou de ser exercida pelos sacerdotes e profetas. No entanto, a autoridade que os sábios têm é bastante grande e vai além de simplesmente interpretar o texto. Como foi visto, há casos em que os sábios podem até chegar ao ponto de anular um mandamento da Torá ou de modificá-lo substancialmente.

Essa autoridade específica de decretar taqanot e guezerôt foi considerada por muitos um abuso da parte dos sábios, e uma distorção das palavras da Torá (cf. especialmente Shelomo Luria, responsa 93); e, por outros, foi considerada uma atividade legítima e adequada, desde 
que pautada por certos princípios (cf. especialmente RAMBAM, 1957, pp. 12-14).

Curiosamente, já na Torá vemos casos de leis explícitas no texto que depois recebem decretos (guezerôt) do próprio texto, com o intuito de ampliar o âmbito de atuação da lei, evitando que a pessoa peque. Ou seja, na própria Torá temos casos de leis anteriores sendo "revogadas" ou "restauradas" para se tornarem mais severas do que originalmente eram.

Por exemplo, pela Torá os sacerdotes são proibidos de entrar em um cemitério (para não se impurificarem), a não ser que seja para acompanhar o funeral de certos tipos de parente, como a mãe, o pai ou o filho. No caso do Sumo Sacerdote, no entanto, a Torá volta atrás no decreto e diz que ele não pode entrar no cemitério e se impurificar nem que os parentes falecidos sejam seu pai ou sua mãe (Levítico 21:11).

Outro exemplo envolve o nazir, a pessoa que resolvia dedicar sua vida ao serviço religioso de modo especial e que, com isso, adotava para si certos votos de abstinência, como não cortar os cabelos e não beber vinho. Embora pela lei original da Torá o nazir deva apenas evitar o vinho (cf. Deuteronômio 6:3), o mandamento do versículo seguinte pode ser encarado como uma guezerá, já que ele pede que o nazir evite qualquer tipo de derivado da uva, inclusive o simples suco de uva.

Agora, que o texto bíblico tenha fenômenos do tipo é algo aceito e bem recebido. Mas de onde os sábios entenderam que eles também deveriam e podiam decretar guezerot, exigindo mais do que a lei explícita no texto escrito?

Em geral o versículo usado como justificativa para isso é o de Levítico 18:30 - E guardareis o Meu mandado, para não praticar nenhum dos costumes abomináveis que foram feitos antes de vós. Daqui os sábios derivaram o mandamento ou a incumbência de "guardar o Meu mandado" (Ievamôt 21a). Esse guardar foi entendido como uma obrigação rabínica de proteger tudo o que foi ordenado na Torá, cuidando da lei do mesmo jeito que alguém cuida de um objeto sob sua guarda (Cf. Rashi de Bêtsa $2 b$, final da explicação do termo vehatania).

Além disso dois outros versículos da Torá corroboram a ideia de que os sábios tinham autoridade legal para emitir guezerot: Conforme o mandado da lei que te ensinarem, e conforme o juízo que te disserem, farás; não te desviarás da sentença que te anunciarem nem à direita nem à esquerda (Deuteronômio 17:11) e Lembra-te dos dias antigos, atentai para os anos das gerações sucessivas; pergunta a teu pai e ele te contará; aos teus anciãos e eles te dirão (Deuteronômio 32:7).

Desnecessário dizer que essa interpretação das coisas e essa autoridade rabínica não foram pontos pacíficos entre todos os judeus ao longo das gerações. Se, por um lado, existem trechos da Torá que parecem dar o poder legislativo total aos juízes, por outro - e essa é uma 
das polêmicas mais frequentemente levantadas ao longo de toda a história legislativa judaica a atividade legislativa dos sábios de emitir guezerôt e taqanot parece contradizer as seguintes palavras de Torá: Tudo quanto eu vos ordeno, isso cuidareis de fazer; não acrescentareis nem subtraireis nada disso (Deuteronômio 13:1).

O grande questionamento é: se o texto diz para não se acrescentar e nem subtrair nada nos ordenamentos dados por Moisés (o que ficou conhecido como princípio Bal Tossif), como os sábios podiam justificar sua atitude legislativa, criando e anulando decretos da Torá?

Duas interpretações interessantes sobre a problemática são apresentadas pelo Rabi Iehudá Halevi e pelo Rambam.

Esta advertência foi dita somente para as massas do povo, para que eles não inventem mandamentos segundo sua cabeça e para que não se considerem capazes de estabelecer para si a Torá segundo suas explicações apenas, como ocorre com os caraítas - e por isso as Escrituras os advertiram para que eles recebessem apenas aquilo que vem dos profetas que surgiram depois de Moisés, e dos "sacerdotes" e dos "juízes"...

A frase "Tudo quanto eu vos ordeno, isso cuidareis de fazer; não acrescentareis nem subtraireis nada disso" significa, na verdade, isto: não acrescentareis nada à palavra que lhes foi ordenada por Moisés, ou pelos "profetas do teu povo, de teu irmão"... ou: não acrescentareis nada à palavra acordada entre os "sacerdotes" e os "juízes" "do local do qual o Eterno escolher" - pois esses recebem inspiração da Presença Divina... Sendo assim, o erro não jaz com eles, sendo eles donos de uma imensa sabedoria.

(Rabi Iehudá Halevi, Cuzarí, 3:40-41)

É possível, e o Tribunal Rabínico de fato pode, legislar e proibir algo que é permitido, e isso acaba se tornando uma proibição para todas as gerações. E, do mesmo modo, eles podem permitir o que é proibido pela Torá se assim o momento o exigir. Sendo assim, o que significa "Tudo quanto eu vos ordeno, isso cuidareis de fazer; não acrescentareis nem subtraireis nada disso"? Que não se deve acrescentar nada às palavras de Torá, e não se deve reduzir nada delas, e estabelecer essas coisas para sempre como se fossem algo da Torá, seja da Torá Escrita, seja da Torá Oral.

Assim, por exemplo, está escrito na Torá: "Não cozinharás o cabrito no leite de sua mãe" (Êxodo 23:19). Segundo o que foi ouvido [a tradição da Torá Oral] aprendeu-se que este versículo proíbe cozinhar e comer a carne com o leite. Isso vale para a carne de animais selvagens e domésticos, mas a carne de aves é permitida no leite pela Torá. Se um Tribunal Rabínico vier e permitir a ingestão de carne de animais domésticos com leite, isso será uma "subtração". E, por outro lado, se vier e proibir a carne de aves, dizendo que ela se enquadra na mesma categoria que a carne de cabrito e que, portanto, é algo proibido pela Torá, isso seria um "acréscimo".

Mas eles podem dizer que a carne de ave é permitida pela Torá e mesmo assim a proibirão, informando ao povo que este é um "decreto" para que não transgridam nada, pois alguém poderia dizer: "a ave é permitida pois aqui não está especificado qual animal doméstico é permitido". Outro virá e dirá: “A carne de animais selvagens então também é permitida, com exceção do cabrito". Virá então outro e dirá: “Até mesmo a carne do cabrito é permitida se for com leite de vaca, ou de ovelha, pois o versículo diz somente "leite de sua mãe", ou seja, da mesma espécie que ele". E virá outro mais e dirá: "Então mesmo no leite da cabra que não é a mãe dele é permitido, porque o versículo diz “mãe dele". Então, sendo assim, eles decidem proibir qualquer 
tipo de carne com leite, mesmo a carne de aves. Nesse caso não é um "acréscimo", mas apenas uma "cerca para a Torá" [uma proteção para que o povo não peque]. $\mathrm{O}$ mesmo vale para todos os casos similares a esse.

(Rambam, Mishnê Torá, Shofetim, Hilchot Mamrim, Cap. 2, Halachá 9).

A visão do Rabi Iehudá Halevi é de que a proibição de acrescentar ou diminuir mandamentos é algo que se aplica somente ao povo, mas não aos sábios.

Já o Rambam, em vez de restringir o uso da aplicação aos sábios ou ao povo, diferencia o que é considerado adição/subtração, e o que não o é. Grosso modo, se os sábios alteram a lei sem maiores explicações, dizendo que ela é derivada da Torá, isso se constitui em adição/subtração e é algo proibido. Mas se existe uma lógica por trás da decisão dos sábios e eles não insistem em afirmar que a lei da Torá é daquele jeito - isto é, se eles deixam claro que aquilo é uma decisão deles - isso não se constitui em adição/subtração e é permitido, sendo considerado apenas uma "cerca para a Torá". Assim, resumidamente, podemos dizer que para o Rambam o problema de violação do princípio de Bal Tossif ocorre se os sábios tentam acrescentar ou diminuir o número de mandamentos da Torá. Pela tradição, são 613 deles, e se os sábios explicitam que existe um a mais ou a menos na própria Torá, isso seria uma violação. No entanto, aumentar ou diminuir detalhes dos 613 mandamentos que já existem (por exemplo, estender a proibição de comer carne de cabrito com leite para a ingestão de carne de ave com leite) seria permitido e não se constituiria em violação do princípio de Bal Tossif.

4.3. Limitações do poder rabínico em emitir decretos

Foi visto anteriormente que embora os sábios tivessem grande autonomia para emitir decretos nos quais viam um resguardo da lei religiosa, essa autoridade não era absoluta e eles se viam limitados por alguns princípios reguladores em sua atividade legislativa. Agora veremos esses princípios em mais detalhes.

\subsubsection{Shev veal taassê (Senta e não faças)}

Foi visto que os sábios podiam decretar que uma lei deixasse de ser cumprida mesmo 
que a Torá a ordene explicitamente. Um bom exemplo é o toque do shofar no dia de Shabat. Mas alguns sábios apontaram que esse princípio tinha uma limitação importante: ele só podia ser aplicado pelos sábios desde que a proibição rabínica não anulasse totalmente o mandamento explícito trazido na Torá.

\subsubsection{Qum assê (Levanta e faça)}

Esse é o princípio oposto do anterior. Segundo ele um Tribunal Rabínico pode ordenar às pessoas fazerem coisas que pela Torá são explicitamente proibidas. No entanto, mais uma vez, isso é aplicado apenas em certos casos. Tal atitude só se justifica como um decreto momentâneo, único e bem definido no tempo, e não como uma lei que passa a valer para sempre dali em diante. Ou seja, esse princípio permite que se ordene o cumprimento de alguma coisa em especial desde que isso seja algo transitório e momentâneo. ${ }^{51}$

No Talmud a motivação para validar a existência deste princípio vem do que ocorreu com Elias e os sacerdotes do deus pagão Baal no Monte Carmel (cf. 1 Reis 18:17-40). Na história pode-se ver que Elias faz um sacrifício no altar num momento em que aquilo era proibido e se configurava em ato passível de excomunhão. Os sábios entenderam, no entanto, que isso foi feito como decisão momentânea, exigida pelas circunstâncias, para fazer com que o povo deixasse de cultuar o deus Baal tornando legítima, portanto, a atitude de Elias.

\subsubsection{Questões financeiras}

Quando o assunto a ser discutido legalmente envolve questões financeiras, os sábios tinham total autoridade para proibir ou permitir certa ação, sem estarem submetidos aos dois conceitos anteriores - shev ve al tassê ou qum assê. Ou seja, nos casos financeiros, os sábios poderiam anular um mandamento da Torá totalmente, ou ordenar que o povo fizesse algo proibido pela Torá, tendo, inclusive, a permissão de fazer com que esse mandamento rabínico

\footnotetext{
${ }^{51} \mathrm{Na}$ opinião do Rav Hisda em Ievamot $89 \mathrm{~b}$, no entanto, os sábios podem revogar uma lei da Torá pelo princípio de qum assê mesmo por um longo período de tempo.
} 
valesse para todas as gerações posteriores, e não fosse apenas uma decisão temporária.

Esse poder maior e quase irrestrito no que diz respeito às questões financeiras vem do princípio chamado de hefqer beit din hefqer, que já foi discutido anteriormente. O assunto é trazido pela primeira vez na Tossefta do tratado de Sheqalim (1:3).

Em outro ponto, no Talmud (Ievamot 89b e Guitin 36b), aparece uma divergência entre o Rabi Itschac e o Rabi Elazar a respeito da validade desse princípio:

\begin{abstract}
O Rabi Itschac disse: De onde se deduz que se o tribunal diz que algo é hefqer ele é de fato hefqer (hefqer beit din hefqer)? Do que foi dito: e que aquele que não viesse dentro dos três dias, conforme a convocação dos príncipes e dos anciãos, toda a sua propriedade seria confiscada (hefqer), e ele seria isolado da congregação dos cativos (Ezrá 10:8). O Rabi Elazar disse que a dedução é daqui: Estas são as heranças que Elazar, o sacerdote, e Josué bin Nun e os cabeças das famílias tribais dos israelitas repartiram (Josué 19:51). E aqui qual é a relação entre os cabeças e os pais? Isso veio para ensinar que do mesmo modo que os pais podem distribuir aos filhos por herança o que eles quiserem, do mesmo modo os cabeças de Israel podem distribuir ao povo por herança tudo o que eles quiserem.
\end{abstract}

(Ievamot 89b)

\title{
4.3.4 Questões conjugais
}

Outro campo no qual os sábios têm autoridade suficiente para revogar totalmente um mandamento da Torá, mesmo sem levar em conta o princípio de qum assê, é a área conjugal.

O princípio por detrás desse poder é enunciado como col hameqadesh edata derabanan meqadesh (todo aquele que santifica uma mulher o faz segundo as ideias dos sábios, Ketuvot 3a).

Ou seja, os sábios poderiam definir que um casamento não foi consumado ainda que ele tenha sido feito segundo as leis da Torá. Nesse caso, o que importa mais é o costume estabelecido pelos sábios, e não pela Torá, como explica o Rashi: "Todo aquele que santifica uma mulher segundo a ideia de costume dos sábios de Israel santifica-a de modo a concretizar o casamento segundo os ditos dos sábios, e isso só pode ser anulado segundo os ditos dos sábios, por meio de cartas de divórcio que os sábios aprovarem" (Ketuvot 3a, comentando a expressão "Todo aquele que santifica"). 
O último princípio regulador da atividade legislativa dos sábios, e o que se constitui em uma das maiores restrições e limitações do seu poder, vem do conceito que afirma que um decreto rabínico só é válido quando a maioria da comunidade é capaz de cumpri-lo. Se um decreto é emitido e grande parte do povo não pode fazer o que é ordenado, o decreto é automaticamente revogado.

Curiosamente, e, fora do que se esperaria, este é um grande poder por parte do povo, ainda que passivamente, para a aceitação ou recusa de um decreto instituído pelos sábios. Interessante relacionar isso com a força do costume (Minhag), abordada anteriormente. Tendo isso em mente, no Mishnê Torá o Rambam aconselha:

"O Tribunal Rabínico que pensa em emitir uma guezerá, ou estabelecer uma taqaná,
ou adotar um costume (Minhag) específico precisa discutir bem o assunto e saber, de
antemão, se a maior parte do povo poderá cumprir o que se pede, ou se eles não são
capazes de fazer o que se pede. Sendo assim, o Tribunal jamais deve decretar algo
sobre o povo, a não ser que a maioria dele possa cumprir o decreto.
Suponha que um Tribunal Rabínico decretou uma guezerá por considerar que a maior
parte da população poderia cumprir o que foi ordenado, mas depois que o decreto foi
emitido viu-se que o povo não tinha como cumprir aquilo em sua maioria; neste caso
o decreto fica imediatamente anulado e o Tribunal não tem o direito de forçar o povo
a agir conforme o que foi imposto". (Rambam, Mishnê Torá, Shofetim, Hilchot Mamrim, Cap. 2, Halachot 5 e 6). 


\section{MÉTODOS DE EXPLICAÇÃO DA TORÁ PARA DEFINIR A LEI}

Depois de ver a relação dos sábios com a lei da Torá e a autoridade que tinham para emitir certos tipos de decretos (ainda que pautados por certos princípios de ação), vamos nos debruçar agora sobre os métodos utilizados por esses sábios para definir a lei a partir do texto escrito da Torá.

O corpus usado para este estudo será o Talmud, já que é um livro no qual os sábios discutem abertamente a respeito das leis estabelecidas e, portanto, oferecem valiosas pistas que revelam como a mente rabínica funcionava no âmbito legislativo.

De maneira geral podemos dividir em dois os métodos principais que os sábios tinham para interpretar o texto sagrado, seja no âmbito da lei, seja fora dele (para derivar significados e lições das histórias bíblicas). O primeiro deles é o que os sábios chamavam de Perush, e que nós hoje chamaríamos de explicação (ou comentários); ou seja uma "tradução" da linguagem do texto, com vistas a esclarecer os termos usados, tornando-os acessíveis para o público da época.

O segundo método é o que os sábios chamavam de Midrash, e que, hoje, poderíamos chamar de "interpretação"; ou seja, algo que vai além de uma mera explicação. O Midrash consiste em investigar a fundo a causa por trás de um versículo da Torá, tentando explicar a intenção dele para assim derivar uma lição de moral ou definir a lei.

Menachem Alon, em seu livro Hamishpat Haivri, ${ }^{52}$ de fato identifica o primeiro tipo de método exegético, o Perush, com a palavra inglesa "commentary"; e o segundo método, o Midrash, com a palavra “interpretation”. E eis o que ele diz sobre o papel da explicação da Torá na definição da Halachá:

O midrash é o método preferencial usado pela halachá, e se assemelha ao conceito latino de Interpretatio, e ao conceito transmitido pela palavra inglesa Interpretation. E, em sua origem, o uso deste termo era diferente do significado da expressão Perush, que, em inglês, equivale ao termo Commentary. (ALON, M. Hamishpat Haivri, v. l, p. 239).

\footnotetext{
${ }^{52}$ Lit. "a justiça hebraica".
} 
Assim, para Alon, é preciso diferenciar os métodos usados pelos sábios na sua relação com o texto sagrado e, mais do que isso, quando se trata de definir a lei, o mais comum, segundo ele, é que se use o método que envolve a interpretação do texto, e não um mero comentário.

Urbach afirma algo similar, mas, acrescenta que o termo Midrash, em sua origem, era usado para se referir ao ato de cumprir os preceitos e mandamentos bíblicos.

O uso do verbo darash em suas diferentes formas no texto bíblico não possui o mesmo significado atual - o mesmo conceito de darash como nós o entendemos - mas sim o de um verbo que denota a ação de cumprir os mandamentos e o próprio esforço feito para segui-los [...] O uso do termo darash no sentido exegético, como método interpretativo da Torá, começa a ocorrer apenas na época de Shmaiá e Avtalion. (URBACH, E. E. Halachá Meqoroteia veHitpatchuta, p. 70).

Com este trecho de Urbach, uma das perguntas que imediatamente se coloca é: quando o Midrash passou a ser usado como forma de definir a Halachá? Será que de fato o Midrash no começo se relacionava com o cumprimento dos mandamentos e posteriormente passou a ser um método de interpretação do texto bíblico? Se sim, quem foram os primeiros a utilizar este método e quando isso ocorreu?

Segundo a maioria dos pesquisadores modernos, foram os escribas os primeiros a usar as interpretações do texto para definir a lei. Não entraremos a fundo nessa discussão, por fugir ao terreno deste trabalho, mas de especial interesse é ver a opinião de Epstein (1957):

"Ezrá, o sacerdote, o erudito - erudito dos mandamentos do Eterno e de Seus estatutos a todo o Israel" (Ezrá 7:11). Em aramaico: "Mestre do Livro da Torá de Deus dos céus" (Ezrá 7:12). Ele é considerado um dos "eruditos" e "iluminados", a ponto de as pessoas "reunirem-se para escutar de Ezrá, o escriba, a exposição da Torá" (Neemias 8:13). A explicação dada para "exposição da Torá" é que ele olhava, investigava e interpretava a Torá. E eis que "eles encontraram escrito na Torá, que o Eterno havia ordenado através de Moisés, que os filhos de Israel deviam habitar em cabanas durante a festa do sétimo mês" (Neemias 8:14).

A explicação dada (por Ezrá e os entendidos) foi: "Ide às colinas e aos montes, e recolhei ramos de oliveira, de murta e de palmeira; ramos de árvores frondosas, para construir cabanas conforme o que está escrito" (Neemias 8:15). Isso mostra que a partir do texto escrito, Ezrá definiu a Halachá.

Este é o início do trabalho dos escribas, e aqui estão os primórdios do Midrash e do Targum [tradução do texto bíblico para o aramaico]. Os escribas que vieram depois de Ezrá deram continuidade ao legado de Ezrá, o escriba, e se encarregavam de comentar o livro, o livro da Torá, e de ensiná-lo ao povo. Assim, os "instrutores de Torá" passaram a ser chamados, desde a época de Ezrá e até a época dos Pares, e, de modo figurado, até a época da destruição do Templo... de escribas.

Os escribas "olhavam na Torá e a interpretavam segundo a sabedoria dos primeiros sábios" (Ben Sira 39:1-3). Comentavam a Torá no que diz respeito às suas leis, suas normas e também suas medidas...

Os escribas, como foi dito, comentavam a Torá e ao mesmo tempo em que a ensinavam com seus comentários, definiam as leis e normas nela contidas. Eles liam na Torá "E será para ti como um sinal sobre tua mão" (Êxodo 13:9) e explicavam: "Isso é uma alusão ao filactério da mão". E liam "como memória entre teus olhos" (Idem) e explicavam: "Isso é uma alusão ao filactério da cabeça"...

Desta maneira, usando o Midrash, os escribas ensinavam a Torá e, desta maneira, 
transmitiam a seus alunos as leis e os preceitos da Torá, juntamente com a Torá Escrita em si. Este método, o Midrash, e apenas este, era o método de ensino utilizado. (Epstein, J. N., Mevoot Lesifrut Hatanaim, pp. 502 - 505).

A ideia de Epstein é uma das mais aceitas atualmente, inclusive por pesquisadores de renome, como Benjamin De Vries. Mas suas ideias também foram refutadas por pesquisadores como Urbach (que defende que Shmaiá e Avtalion foram os precursores do Midrash) e Liberman.

Independentemente de quem foram os primeiros a usar o Midrash e se este realmente foi o primeiro e único elemento usado para definir a lei religiosa, fato é que este sistema interpretativo chegou às mãos dos sábios do Talmud e por eles, de fato, foi muito utilizado. As origens do Midrash e sua evolução até chegar à época do Talmud se constitui numa pesquisa à parte. Mas, sendo uma ferramenta amplamente usada pelos amoraítas, fica fácil ver que é preciso entender o uso desta técnica pois ela se constitui em importante elemento usado pelos sábios para definir a Halachá, provavelmente desde muito antes da época de compilação da Mishná.

\subsection{Midrash}

Se considerarmos que o Midrash é, então, um método de explicação da Torá, nos deparamos com um segundo ponto: ao analisarmos o texto do Pentateuco vemos que ele pode ser dividido basicamente em duas partes. Uma parte dele é composta de histórias e relatos; e a outra parte é a das leis e regulamentos.

Assim sendo, quando se fala de Midrash como método explicativo da Torá, é costume diferenciar entre dois tipos dele, cada um ligado a uma das duas partes da Torá. O Midrash que interpreta as histórias e relatos bíblicos, às vezes trazendo informações adicionais e completando "lacunas" nos relatos, chama-se Midrash Agadá. Esse é um tipo de Midrash, que, via de regra, se baseia nos textos bíblicos para derivar dele lições de moral e ética, e tem um aspecto fortemente pedagógico. O outro tipo de Midrash, que se ocupa de entender o texto para definir a lei, chama-se Midrash Halachá. Neste trabalho vamos nos ocupar apenas com este último tipo.

No livro Mishnê Torá (Shofetim, Hilchot Maamarim, 1:2), o Rambam define que tudo aquilo que é apreendido através da interpretação do texto bíblico - através do Midrash - faz 
parte da Torá Oral. E ele afirma que a informação derivada do Midrash pode ser de três tipos.

1. Uma ideia que já era transmitida e passada de geração em geração; ;3 $^{53}$

2. Um ensinamento aprendido por um dos treze modos de interpretação da Torá;

3. Decretos, regulamentos e costumes (taqanot, guezerot e minhag). ${ }^{54}$

O item número 2 é um dos mais importantes no que diz respeito à definição da lei pelos sábios e pode-se dizer sem exagero que é este o ponto central do Midrash Halachá. Muitas vezes os itens 2 e 3 da definição do Rambam se misturam e se tornam uma unidade.

Não há discórdia entre os pesquisadores quanto ao fato de que as primeiras formas de Midrash a surgirem foram as formas exegéticas, que, em essência, eram interpretações de termos e expressões do texto sagrado, muitas vezes sem se preocupar com a definição da lei propriamente dita (Cf. EPSTEIN, 1957, pp. 502-505).

Lieberman (1984, p. 186), por exemplo, afirma que "A principal função de um comentarista da Torá era explicar a realia e traduzir as expressões estranhas e difíceis para um hebraico mais simples, ou, por vezes, para o aramaico". Lieberman, em seguida, chega a identificar e listar expressões usadas pelos sábios no Talmud para fazer esse tipo de comentário, como ein ... êla (אין (אל ... não é isso... mas sim isso). ${ }^{55}$

No entanto, embora os primórdios do Midrash sejam muito provavelmente linguísticos, de fato rapidamente eles se expandiram e começaram a incluir outros tipos de análise e comentários, pois para os envolvidos com o estudo da Torá não se tratava apenas de conhecer o texto como em um estudo histórico-arqueológico, tentando entender expressões usadas no passado. Antes, para os estudiosos da Torá tudo girava ao redor do objetivo de reconhecer o texto como uma "Torá Viva”, um livro que devia pautar a vida judaica daquele então.

Dos registros que temos em mãos, sabemos que na época de Hilel e Shamai, quando os judeus estavam sob domínio do Rei Herodes (final do século I a.e.c e começo do século I d.e.c), o uso do Midrash já estava extremamente difundido e o próprio Hilel era considerado um dos "pais" do sistema do Midrash.

Segundo o que está relatado no Talmud de Jerusalém, um dos motivos que fez com

\footnotetext{
${ }^{53}$ Confira a discussão sobre a tradição e o estabelecimento da lei supra,, Cap. 1 e 2.

${ }^{54}$ Confira supra, Cap. 4.

${ }^{55}$ Para uma discussão mais aprofundada sobre a datação do uso do Midrash, cf. DE VRIES (1966)[1], URBACH (1984), LIEBERMAN (1984) e, principalmente, GOLDBERG (1981).
} 
que Hilel saísse da Babilônia e fosse para Israel foi justamente a necessidade de interpretar as Escrituras.

\begin{abstract}
Por conta de três coisas Hilel saiu da Babilônia e foi para Israel.
Ele é puro (Levítico 13:37). Isso significa que ele vê que a chaga é pura e não diz nada? Não, por isso o texto veio e ensinou que "e o sacerdote o purificará" (Levítico 13:37). Se o sacerdote purificar, está purificado; mas se o sacerdote purificar o que ainda está impuro, considera-se purificado? Não, por isso o texto veio e ensinou "ele é puro" e "e o sacerdote o purificará". Para isso Hilel veio da Babilônia. (Talmud de Jerusalém, Pessachim 86).
\end{abstract}

Segundo a Torá, uma pessoa, uma roupa ou uma casa afetadas por qualquer tipo de chaga, como a lepra, é declarada impura até estar curado da chaga. A determinação e o exame sobre se algo ainda está impuro ou se já foi curado (e, portanto, puro) é feito pelo sacerdote. Sobre um dos casos que o sacerdote precisa julgar se a mácula foi curada, a Torá diz: "ele é puro, e o sacerdote o purificará" (Levítico 13:37). É com base nessa repetição ("puro" e "purificará") que Hilel monta a sua explicação da lei. Ele defende que se estivesse escrito apenas "ele é puro", as pessoas poderiam entender que bastava o sacerdote olhar a mancha e não dizer nada. E, por outro lado, se estivesse escrito apenas "e o sacerdote o purificará", as pessoas poderiam entender que mesmo que o sacerdote tivesse dito que algo impuro é puro, a coisa seria pura. Então a Torá escreveu duas vezes uma expressão similar, segundo Hilel, para mostrar que se tratam de duas condições a serem cumpridas: o sacerdote tem que proferir em voz alta que o objeto é puro, e o objeto tem que de fato ser puro para que o enunciado do sacerdote seja válido.

Um versículo diz: "E sacrificarás, do rebanho e do gado, o Pêssach ao Eterno, teu Deus" (Deuteronômio 16:2). E em outro local está escrito: "dos carneiros e das cabras haveis de tomá-lo" (Êxodo 12:5). Como pode ser? O rebanho é para Pêssach e o rebanho e o gado são para Chaguigá. ${ }^{56}$ (Talmud de Jerusalém, Pessachim 86).

Agora a questão legal envolve uma contradição entre um versículo de Deuteronômio e um versículo do Êxodo. Do primeiro versículo fica claro que o sacrifício da festa de Pêssach pode ser feito com um animal do rebanho ou do gado. No entanto, do versículo do Êxodo fíca claro que o sacrifício de Pêssach pode ser apenas do rebanho. Hilel explica que o versículo que permite apenas o sacrifício de rebanho se refere ao sacrifício feito para a festa de Pêssach, e que o versículo que permite os dois tipos de sacrifício alude ao sacríficio de Chaguigá, um sacrifício que era ofertado em todas as festas e que, portanto, era levado junto com o sacrifício de Pêssach.

\footnotetext{
${ }^{56}$ A explicação de cada sacrifício aparece adiante.
} 
Um versículo diz "seis dias comerás pães não fermentados" (Deuteronômio 16:8). E em outro local está escrito "sete dias comereis pães não fermentados" (Êxodo 12:15). Como pode ser? Seis dias da nova e sete da antiga. (Talmud de Jerusalém, Pessachim $86)$.

Aqui novamente existe uma contradição entre dois versículos. Do primeiro, em Deuteronômio, decorre o mandamento de que se coma o pão não fermentado (matsá) por seis dias; já o segundo versículo traz a cifra de sete dias. Hilel explica que como o sacrifício do Ômer é feito no segundo dia de Pêssach, e só depois é permitido comer da nova safra, isso significa que a contar da nova colhita é permitido comer por seis dias; mas da safra antiga é permitido comer sete dias.

O Talmud encerra esses três exemplos resolvidos por Hilel dizendo: E ele explicou e consentiu, e foi aceito e se tornou lei.

Estes trechos do Talmud são um excelente exemplo de como os sábios, e Hilel, em particular, usavam o método do midrash para definir a lei. Entende-se também por que eles o consideravam de suma importância, pois podiam modificar totalmente o entendimento sobre como cumprir um mandamento. O Talmud relata que o uso dessas técnicas era tão difundido que os sábios usavam o Midrash até mesmo para interpretar outros documentos e textos que nada tinham a ver com a religião, e que não eram sagrados (cf. Tossefta Ketuvot 84, onde o texto de um contrato de casamento é analisado).

5.2. Tipos de Midrash e suas aplicações

Dentro do método geral chamado Midrash, uma tradição atribui a Hilel a formulação de sete princípios midráshicos pelos quais a Torá é interpretada: ${ }^{57}$
1. Qal vachômer
2. Guezerá Shavá
3. Binian av mi catuv echad
4. Binian av mi shenê ketuvim
5. Clal ufrat e prat uchlal

\footnotetext{
${ }^{57}$ Existe uma variação na formulação dos sete princípios na Tossefta de San 'hedrin 7:11 e na introdução ao Sifra 3a. Aqui foi utilizada a versão da Tossefta.
} 


\title{
6. Caiotsê bo mimaqom acher \\ 7. Davar halamed meinianô $\hat{~}^{58}$
}

Muito provavelmente esses princípios já existiam antes de Hilel, porém ele foi, quiçá, o que mais os utilizou e por isso ficou reconhecido como o "fundador" desses princípios.

\begin{abstract}
Não foi Hilel quem renovou o Midrash e o estabeleceu de forma a compreender sete princípios, mas era ele quem interpretava com base nos sete princípios diante dos anciãos da Torá. (EPSTEIN, 1957, pp. 510).
\end{abstract}

Ou seja, tudo que Hilel estava fazendo, segundo Epstein, era se basear em métodos hermenêuticos já conhecidos anteriormente a ele para definir a Halachá, como no trecho do Talmud em que vemos Hilel estabelecendo três leis a partir do texto escrito da Torá.

O mesmo afirma Lieberman (1984, p. 190): "Pela relação dos assuntos, vê-se que Hilel não inventou esses princípios e métodos sozinho. Tudo o que ele fez foi utilizar caminhos comprovados da tradição... Ele precisava dos sete princípios de explanação para provar uma lei a partir da Torá".

Shamai, parceiro contemporâneo de Hilel, também usava o midrash para definir a lei (cf. Sifri Devarim 203) e, portanto, os discípulos de ambos os sábios, chamados no Talmud de Beit Hilel e Beit Shamai, continuaram se fiando no Midrash para interpretar as Escrituras e definir a lei depois que seus mestres já tinham morrido.

São famosas as diversas divergências de opinião entre as duas escolas e, curiosamente, todas elas se baseiam puramente em questões midráshicas do texto. Por exemplo:

\begin{abstract}
A Escola de Shamai diz: à noite todo homem deve deitar e recitar (a oração do Shemá); e, de manhã, deve ficar de pé, pois está dito: "ao deitar-te e ao levantar-te" (Deuteronômio 6:7). A Escola de Hilel diz: todo homem lê como deseja, pois está dito: "andando pelo seu caminho" (Idem). Se é assim, por que foi dito "ao deitar-te e ao levantar-te"? Isso significa: na hora em que as pessoas deitam e na hora em que as pessoas levantam. (Berachot 1:3).
\end{abstract}

A discussão entre as duas escolas é sobre como se deve recitar o texto do Shemá. Ambas concordam que o texto deve ser proferido pelo menos duas vezes por dia, ao ir dormir e ao acordar. No entanto, a Escola de Shamai diz que, ao dormir, deve-se proferir o texto deitado, e, ao acordar, de pé, pois está escrito "ao deitar-te e ao levantar-te" (Deuteronômio 6:7). Já a Escola de Hilel não entende o versículo como uma explicação da postura que se deve adotar, mas sim como uma referência ao momento correto da leitura do texto. Para a Escola de Hilel, a existência do versículo "andando pelo seu caminho" (Idem) implica que cada um pode

\footnotetext{
${ }^{58}$ Para detalhes sobre cada princípio e a expansão deles levada a cabo pelo Rabi Ishmael, confira 5.3.
} 
recitar o texto do seu jeito.

Embora haja evidências de amplo uso do Midrash por sábios como Hilel e Shamai, e seus contemporâneos, pode-se dizer que o florescimento do uso do Midrash de fato ocorreu na época do Rabi Akiva ${ }^{59}$ e do Rabi Ishmael ${ }^{60}$ (EPSTEIN, 1957, pp. 512-515). Deste momento em diante o midrash foi adotado como método interpretativo legislativo e se expandiu cada vez mais, com a concomitante difusão dos textos da Torá Oral, como a Mishná. Ao final da época da compilação da Mishná vê-se que os sábios continuavam usando o Midrash e uma fonte chega a dizer, por exemplo, que o Rabi Eliezer, filho do Rabi Iossi, o Galileu, usava 32 métodos de midrash para interpretar o texto bíblico. ${ }^{61}$ Analisando a lista de métodos midráshicos atribuídos ao Rabi Eliezer, percebe-se que pouquíssimos deles são realmente anteriores a ele, que foi um dos últimos alunos do Rabi Akiva. Ou seja, a maioria dos 32 métodos listados neste caso eram, de fato, formas midráshicas criadas por ele ou em sua época.

Obviamente, como método de suma importância, o midrash também foi usado pelos amoraítas, compiladores do Talmud. No entanto, a este respeito existe uma divergência entre os pesquisadores quanto à questão se os amoraítas criaram novas leis usando o midrash ou não. Isso é: os amoraítas continuavam criando leis e decretando coisas para que o povo as cumprisse ou eles simplesmente se debruçavam sobre as leis que já existiam até a sua época e tentavam achar explicações para elas baseando-se no midrash?

Segundo Frankel (1923, p. 17), os amoraítas, em geral, não definiam a halachá por meio do midrash, e, segundo ele, é preciso diferenciar o midrash usado pelos tanaítas, que formava halachá, e o midrash dos seus sucessores, que usavam o método apenas para tentar encontrar motivos e explicações para as leis definidas pelos tanaítas, como um mero exercício intelectual.

De Vries (1966, p.23) concorda com Frankel, e afirma que

"o midrash dos amoraítas é usado quase que exclusivamente para explicar as leis e decretos [...] para resolver contradições entre ideias específicas das Escrituras, ou entre a tradição das interpretações existentes na época".

Por outro lado, pesquisadores como Guilat (1979, p. 212) discordam da posição de Frankel:

\footnotetext{
${ }^{59}$ Sábio tanaíta da segunda metade do primeiro século da era comum. Um dos sábios de maior renome no judaísmo até os dias de hoje. Mencionado diversas vezes na Mishná e chamado no Talmud de Rosh lachachamim (Cabeça dos sábios).

${ }^{60}$ Sábio tanaíta do final do primeiro século da era comum. Seu sistema exegético é frequentemente contraposto ao do Rabi Akiva e, em geral, considerado mais lógico.

${ }^{61}$ Uma lista dos 32 princípios geralmente é publicada em cada edição do Talmud na edição de Vilna e nas edições posteriores a ela, ao final do Tratado de Berachot.
} 
O mesmo que fizeram os tanaítas, fizeram os amoraítas. Eles também se envolveram com a decisão legal e decretaram leis novas baseando-se no midrash das Escrituras. Os próprios rishonim ${ }^{62}$ reconhecem isso: "Isso foi o que recebemos de alguns decretos criados e que ouvimos dos amoraítas, coisas que foram explicadas com base na força do versículo, sem que tenhamos encontrado alusões a essas leis nas palavras dos tanaítas" (Shita Mequbétset $15 \mathrm{a})^{63}$. Desde que surgiu a necessidade de definir a lei, os amoraítas, logo do início, acharam as respostas e soluções com a ajuda das compilações de halachá já definidas na época: mishná, tossefta, midrash halachá e beraitot. ${ }^{64} \mathrm{E}$ mesmo quando esse tipo de halachá era inexistente na tradição tanaíta, os amoraítas voltavam-se para as Escrituras e, baseados na sua lógica e no seus métodos interpretativos dos versículos da Torá, definiam a halachá.

\subsubsection{Midrash explicativo}

Tendo visto um pouco do histórico do Midrash, podemos começar a categorizar os tipos de Midrash usados no Talmud. A primeira aplicação do midrash parece muito com uma simples explicação das palavras do texto. Sua principal função é esclarecer um trecho das Escrituras, para facilitar o entendimento. Em geral, esse midrash gira ao redor de uma palavra ou expressão, só que a explicação do elemento em questão permite uma expansão de conhecimento que os sábios então utilizam para definir a halachá.

5.2.1.1. Exemplos de leis aprendidas por conta de um midrash explicativo

Na Torá está escrito “Quando comprares um escravo hebreu, ele servirá por seis anos e no sétimo sairá livre, de graça" (Êxodo 21:2). A palavra "sétimo" nesse versículo pode ter dois significados: 1) o sétimo ano de trabalho do escravo, o que significa que o escravo deve ser liberado depois de trabalhar por seis anos; ou 2) o sétimo ano na contagem dos anos do ciclo sabático ordenados pelo Antigo Testamento. Se o significado correto for o segundo, então nem sempre o escravo trabalhará seis anos, mas apenas a diferença entre os anos que faltam para o sétimo ano sabático e o ano em que ele foi comprado.

\footnotetext{
62 Grupo de sábios de três épocas posteriores aos amoraítas, que viveram entre o século XI e o XI, aproximadamente.

${ }^{63}$ Famoso comentário talmúdico escrito por Bezalel ben Abraham Ashkenazi no século XVI. Bezalel também se tornou famoso por ter sido mestre do famoso cabalista Rabi Isaac Luria.

${ }^{64}$ A Beraita é a compilação de ensinamentos da Torá Oral que, por algum motivo, não entraram na Mishná. Frequentemente o texto é usado pelos sábios do Talmud para contrapor o que está definido na Mishná, como uma segunda versão dos ensinamentos.
} 
Para dirimir a dúvida entre as duas formas de interpretação, eis como o Midrash explica a expressão "no sétimo":

No sétimo. Sétimo ano da venda. Você diz que é o sétimo ano desde a venda do escravo, mas por que não o sétimo ano do ciclo de sete anos? Porque o versículo ensina "ele servirá por seis anos". Então é o sétimo ano da venda, e não do ciclo dos sete anos. (Mechilta de Rabi Ishmael, Nezikin, 1).

O midrash explica a expressão "no sétimo" como ligada à expressão “ele servirá por seis anos", ou seja, o escravo precisa, necessariamente, trabalhar por seis anos para ser libertado no sétimo.

A forma usada nesse midrash explicativo é muito comum e padrão, merecendo ser destacada: o interpretador começa mencionando a expressão ou frase que quer analisar, e dando a explicação que lhe parece mais correta: No sétimo. Sétimo ano da venda.

Passa-se, então a explicar por que esta é a opinião correta, trazendo, antes, a outra interpretação possível: Tu dizes que é o sétimo ano desde a venda do escravo, mas por que não o sétimo ano do ciclo de sete anos? Por fim, o intérprete conclui com uma prova de que a sua interpretação é de fato a certa: o versículo ensina "ele servirá por seis anos". Então é o sétimo ano da venda, e não do ciclo dos sete anos.

Este é um exemplo clássico de midrash explicativo usado no Talmud, que ao interpretar uma palavra ou expressão de um versículo pode definir a halachá.

Outro exemplo pode-se ver a respeito da leitura do Shemá. Na Torá está escrito: “e as inculcarás a teus filhos, e delas falarás sentado em tua casa e andando pelo caminho, ao deitarte e ao levantar-te" (Deuteronômio 6:7). A definição da expressão "ao deitar-te e ao levantarte" gerou uma divisão de ideias entre a Escola de Shamai e a Escola de Hilel:

\footnotetext{
A Escola de Shamai diz: à noite, todo homem deve se deitar e recitar; e, pela manhã, deve ficar de pé, pois está dito: "ao deitar-te e ao levantar-te". A Escola de Hilel diz: todo homem lê como quiser, pois está dito: "andando pelo seu caminho". Se é assim, por que foi dito "ao deitar-te e ao levantar-te"? Na hora de se deitar e na hora de se levantar (Berachot, 1:3).
}

O problema aqui está na expressão "ao deitar-te e ao levantar-te", que pode ser uma descrição de estado ou de tempo. A Escola de Shamai entende a expressão como uma descrição de estado, a pessoa tem que estar deitada ou de pé para proferir a reza. Já a Escola de Hilel entende isso como uma descrição de tempo, no qual a pessoa deve rezar quando for deitar e quando levantar. 


\subsubsection{Leis aprendidas do Vav conectivo}

Dentro do caso do midrash explicativo, pode-se falar do caso especial do Vav conectivo. Frequentemente a letra Vav aparece nas Escrituras atuando como a conjunção "e" do português, ou seja, com a função de unir e conectar dois termos. Em várias ocasiões os sábios se debruçam sobre a interpretação desse Vav para poder definir a lei. Por isso, este pode ser entendido como um subcaso de midrash explicativo.

Por exemplo, o texto bíblico diz: "E tomareis para vós, no primeiro dia, o fruto da árvore formosa (Etrôg), palmas de palmeira e ramos de murto e de salgueiro de ribeiras, e vos alegrareis diante do Eterno, vosso Deus, por sete dias" (Levítico 23:40). Sobre esse versículo, o Midrash diz:

O Rabi Elazar diz: É possível cumprir o mandamento mesmo quando o etrôg está junto com as outras espécies? Não, apenas se estivesse escrito: "o fruto da árvore formosa e palmas de palmeira". Mas, do jeito que está escrito, aprende-se que o etrôg vai sozinho e as outras três espécies em conjunto.

(Sifra, Emor, 16:7)

Ou seja, como existe o Vav conectivo (traduzido por "e") entre os termos "palmas de palmeira", "ramos de murto" e "salgueiro de ribeiras", o Rabi Elazar entendeu que estas três espécies devem constituir um só feixe. Da ausência do Vav conectivo entre "fruto da árvore formosa" e "palmas de palmeira", o Rabi Elazar entendeu que o etrôg não deve ser posto no mesmo feixe que as outras espécies.

Daqui decorre uma pergunta que é analisada pelos sábios: o Vav sempre é um conectivo? Vejamos outro midrash:

E aquele que maldizer a seu pai e a sua mãe, certamente será morto (Êxodo 21:17). Não se deve ler pai e mãe, mas também a mãe, sem o pai; e o pai sem a mãe... O Rabi Ionatan diz: se o significado fosse os dois juntos, o texto traria e expressão "juntos", como se fossem um. Como não ocorreu isso, trata-se de cada um por separado.

(Sifra, Qedoshim, Capítulo 9:5)

O Rabi Ionatan explica que embora o versículo diga "pai e mãe" o significado é "pai" 
ou "mãe" e que, neste caso, o Vav desempenha uma função optativa. ${ }^{65}$

\subsubsection{Midrash lógico}

O midrash lógico é um segundo tipo de aplicação dessa forma exegética e ela se parece muito com o midrash explicativo, pois através dela os sábios também acabam explicando e detalhando o texto, permitindo uma melhor compreensão e a definição da halachá. No entanto, em vez de se basear em uma expressão ou palavra do texto que dê a chave interpretativa do versículo (elementos intratextuais), esse midrash se baseia na lógica e no senso comum (elementos extratextuais).

E se o homem achar uma moça desposada no campo, e o homem a forçar e se deitar com ela, então morrerá somente o homem que se deitou com ela. Mas à moça não farás nada; a moça não tem pecado de morte porque, como no caso do homem que se levanta contra o seu companheiro e o mata, assim também é este caso; pois no campo a achou: a moça desposada gritou e não houve quem a salvasse.

(Deuteronômio 22:25-27)

Da linguagem dos versículos pode parecer, pelo sentido literal, que a moça violentada está livre de castigos só se o estupro se deu no campo. Isso é destacado duas vezes no texto. No entanto, os sábios explicaram o versículo da seguinte forma:

\footnotetext{
"Pois no campo a achou". Pode ser que se o fato ocorreu na cidade ela pode ser punida e apenas no campo ela está isenta? Não, e o versículo ensina isso quando diz: "a moça desposada gritou e não houve quem a salvasse". Isso significa que se houvesse quem a salvasse, seja no campo ou na cidade, ela pode ser punida, mas, se não, mesmo no campo ou na cidade ela está isenta.
}

(Sifra, Devarim 243)

O intérprete explica o versículo do modo lógico. Não é o local do estupro que determina se a mulher será castigada ou não. Ou seja, se a mulher de fato foi violentada, não

\footnotetext{
${ }^{65}$ É interessante notar que dependo da construção sintática das frases, vários idiomas do mundo passam pelo mesmo problema no que diz respeito ao valor semântico das conjunções aditivas e alternativas. No caso do português, isso se dá com a conjunção "ou", que, em alguns casos pode ter o seu valor ambíguo, por exemplo: "Este celular se conecta à internet por Wi-fi ou por 3G". O celular se conecta com os dois sistemas, e o "ou" tem valor aditivo, embora seja usado para informar que não é possível usar os dois sistemas ao mesmo tempo.

Para mais informações sobre o Vav e seus usos, cf. EPSTEIN (1964), pp. 1050-1110.
} 
importa se no campo ou na cidade (e o grito é uma das provas da violência sofrida), ela está livre de qualquer castigo.

Outro exemplo de uso da lógica para definir a halachá.

(Se algum homem vier obrigar seu próximo a dar-lhe um penhor sobre a dívida,) não lhe tomará em penhor nem a mó de baixo nem a mó de cima, porque são coisas com as quais se elabora o alimento do homem (Deuteronômio 24:6).

O versículo define, explicitamente, que é proibido pegar como objeto de penhora as mós do devedor, pois a pessoa precisa delas para o seu sustento. No Midrash dessa passagem os sábios dizem: "Nem a mó de baixo nem a mó de cima”. Isso não vale só para as mós. Por isso o versículo ensina: "coisas com as quais se elabora o alimento do homem” (Sifri, Devarim 272).

Usando o senso comum, os sábios entenderam que a alusão às mós é apenas um exemplo de qualquer objeto usado para elaborar o alimento do homem, para the dar sustento. Portanto, nenhum objeto usado com essa finalidade - e não só as mós - pode ser posto em penhora.

Outro exemplo se vê a respeito do sacrifício de Pêssach, quando a Torá diz: "Toda a assembléia da congregação de Israel o degolará à tarde" (Êxodo 12:6). E sobre isso o Midrash diz: O degolará. Por acaso cada membro da assembléia da congregação de Israel o degolará? Não, cada um envia o seu sacrifício e é como se a pessoa que enviou tivesse degolado (Mechilta de Rabi Ishmael, Pessach, 5). ${ }^{66}$

A questão do comentarista é: como o versículo diz que toda congregação deve sacrificar o animal se só os sacerdotes podem fazer isso? Por acaso cada um poderia degolar seu próprio animal? Baseando-se na lógica da lei, o comentarista conclui que toda congregação deve enviar o animal ao sacerdote e quando ele o sacrificar isso equivale a um sacrifício feito pela própria pessoa.

\subsubsection{Midrash exemplificador}

Os dois tipos de Midrash discutidos até aqui em geral são usados para explicar leis já

\footnotetext{
${ }^{66}$ Mechilta é um termo aramaico que alude a um conjunto de regras de interpretação. A Mechilta do Rabi Ishmael se debruça sobre o Livro do Êxodo como objeto de suas análises legalistas.
} 
recebidas e estabelecidas na tradição, ou leis que estão explícitas na Torá. Por meio da explicação dessas leis traz-se uma expansão de significado e uma aplicação mais ampla da mesma. Então, por exemplo, a lei do sacrifício de Pêssach já existia, e o midrash veio apenas para explicar que a degola do animal é feita pelo sacerdote.

No entanto, às vezes, os sábios do Talmud se deparavam com problemas novos, questões de sua época, e para os quais não era possível encontrar uma explicação ou lei descrita explicitamente na Torá. Nestes casos, o uso do Midrash lógico ou explicativo não servia para responder às perguntas e resolver os problemas que surgiam. Quando era esse o caso, os sábios aplicavam o que se pode chamar de Midrash exemplificador.

Pode-se entender esse tipo de Midrash como um midrash analógico, comparativo, que estabelece uma relação de igualdade entre um assunto e outro, ou entre um tópico e outro. Por meio dessa relação de igualdade os sábios conseguiam achar a lógica para definir a lei para o caso novo que se estava debatendo.

\subsubsection{Analogia explícita}

Às vezes a própria Torá estabelece uma comparação entre dois assuntos, o que dá aos sábios a margem para definir uma lei. No caso da mulher violentada, por exemplo, visto anteriormente, a Torá determina: "Mas à moça não farás nada; a moça não tem pecado de morte porque, como no caso do homem que se levanta contra o seu companheiro e o mata, assim também é este caso" (Deuteronômio 22:26).

Ou seja, neste caso a própria Torá compara a situação da jovem violentada, que gritou, com a situação de uma pessoa que foi assassinada. Trata-se portanto de uma analogia explícita no próprio versículo. Com base nisso, dizem os sábios:

O Rabi diz: "porque, como no caso do homem que se levanta contra o seu companheiro e o mata, assim também é este caso" (Deuteronômio 22:26). Nós não aprendemos que a moça não deve ser morta por comparar o seu caso com o do homem que mata o seu companheiro, mas justamente o oposto, é o caso da moça que ensina algo sobre o caso do homem que mata seu companheiro. Do mesmo modo que é permitido matar aquele que tentou violentar uma mulher [se não houver outro jeito de evitar o estupro], pode-se matar aquele que vai atrás de seu companheiro para matálo [se não houver outro jeito de evitar o assassinato]. E a equivalência entre a mulher violentada e o homem que se levanta para matar seu companheiro também ensina que do mesmo jeito que se deve tentar poupar a vida do que deseja matar o seu companheiro, deve-se tentar poupar a vida daquele que deseja cometer um estupro. 
(TB, San'hedrin 74a)

\subsubsection{Analogia geral}

A analogia geral não vem expressa abertamente no versículo, como no caso anterior, mas é derivada pelos sábios usando algum método do midrash aplicado com esta finalidade.

Na Torá está escrito: "E chegar-se-ão os sacerdotes, filhos de Levi, pois a eles escolheu o Eterno, teu Deus, para servi-Lo e para abençoarem em Nome do Eterno, e por sua sentença será resolvida toda demanda e toda chaga" (Deuteronômio 21:5).

Desse versículo decorre que os sacerdotes têm a autoridade para decidir todos os casos de disputas e demandas (questões financeiras), e todos os casos ligados a chagas (questões de pureza e impureza).

Como o versículo traz esses dois assuntos juntos, os sábios estabeleceram uma analogia geral entre aquelas duas áreas. Eis o que eles dizem:

\footnotetext{
"E por sua sentença será resolvida toda demanda e toda chaga". Existe uma relação entre as demandas e as chagas. Do mesmo jeito que eles só tratam das chagas de dia, também só devem tratar das demandas de dia. Do mesmo jeito que eles só tratam das demandas que não sejam de parentes, também só devem tratar das chagas que não sejam de parentes.
}

(Sifri Devarim, 208)

Do versículo "E o dia em que aparecer nela carne viva será impuro" (Levítico 13:14), os sábios aprenderam que a decisão sobre a pureza ou impureza das chagas só deve ser feita de dia, e é proibida à noite. Por conta da analogia geral, os sábios também entenderam que a decisão sobre disputas e demandas financeiras só pode ser julgada de dia.

Também há um aprendizado no sentido oposto. Do mesmo jeito que as demandas financeiras não podem ser julgadas por parentes dos envolvidos no litígio, as questões de pureza e impureza das chagas também não podem ser julgadas por parentes da pessoa afetada pela doença.

\subsubsection{Analogia por proximidade}


Às vezes os sábios derivam uma lei da proximidade de dois assuntos na sequência textual e, com base nisso, estabelecem uma analogia entre os dois casos.

Por exemplo, o versículo de Êxodo 22:17 diz: "Feiticeira não deixarás viver" e imediatamente em seguida aparece: "Todo aquele que tiver coito com um animal será morto" (Êxodo 22:18).

Com respeito ao que se deita com um animal, o Rabi Akiva defende que a morte do transgressor deve se dar por enforcamento. E dessa sua opinião o Rabi Iossi, o Galileu, aprendeu: Está dito: "feiticeira não deixarás viver", e está dito: "Todo aquele que tiver coito com um animal será morto", por enforcamento. Do mesmo jeito que em um caso se aplica o enforcamento, no outro caso se aplica o enforcamento (Mechilta de Rabi Ishmael, Nezikin, 17).

\subsubsection{Midrash restritor}

Há casos em que o Midrash não vem para expandir e acrescentar detalhes à lei, dando novas aplicações a ela, mas para limitar e especificar a aplicação legal, restringindo, portanto a questão jurídica. Vejamos dois exemplos de Midrash que pode ser chamado restritor.

5.2.4.1. Restrição da proibição de "não entrará na congregação do Eterno"

Na Torá está escrito: "Nenhum amonita nem moabita entrará na congregação do Eterno [...] eternamente, pelo mau conselho que deram e porque não vos receberam com pão e com água no caminho" (Deuteronômio 23:4-5).

O texto da Mishná diz: Amonita nem moabita. Proibidos, e é uma proibição para todo o sempre. Mas as suas mulheres são permitidas (Ievamot 8:3).

Do modo como o versículo foi escrito, não parece haver distinção entre os tipos de amonitas e moabitas - não importa se são homens ou mulheres - ambos estão proibidos. No entanto, a Mishná determinou que a probição se aplica somente aos homens; portanto, mulheres amonitas e moabitas podem se converter e podem entrar na comunidade de Israel.

Isso foi aprendido por meio de um Midrash restritor: 
Nenhum amonita nem moabita entrará na congregação do Eterno. O versículo está usando o termo masculino, e, portanto, fala apenas dos homens, mas não das mulheres; de nenhum amonita ou moabita, mas não de nenhuma amonita ou moabita. O Rabi Iehudá e os outros sábios ainda disseram: "porque não vos receberam com pão e com água no caminho”. Quem costuma fazer isso? Os homens, e não as mulheres.

(Sifri Devarim, 249) ${ }^{67}$

5.2.4.2. A lei do filho teimoso e rebelde

Na Torá existe o caso que ficou conhecido como o do "filho teimoso e rebelde". A Torá diz: "Quando um homem tiver um filho teimoso e rebelde, que não obedece à voz de seu pai e à voz de sua mãe, e ainda que o castiguem não lhes dá ouvidos, pegarão nele seu pai e sua mãe e o levarão aos anciãos de sua cidade e à porta do tribunal do seu lugar, e dirão aos anciãos de sua cidade: Este nosso filho é teimoso e rebelde, não obedece à nossa voz; é glutão e beberrão. E todos os homens da sua cidade o apedrejarão e morrerá, e eliminarás o mal do meio de ti; e todo o Israel ouvirá e temerá" (Deuteronômio 21:18-21).

Os sábios viram a necessidade de analisar melhor as palavras de Torá e, por meio dessas análises, restringiram a aplicação desta lei:

“Quando um homem tiver um filho”... Um filho, e não uma filha. Um filho, e não um adulto [que mora sem os pais] e nem um menor de idade, que não cumpre os mandamentos de modo geral.

(Sifri Devarim, 218)

Ou seja, pelo Midrash restritor aplicado aqui, a lei do filho rebelde e teimoso não se aplica às meninas, nem ao menor de idade (o jovem que não chegou aos treze anos) e nem a um homem adulto. Além disso, o Talmud aplica outras restrições: a lei só é válida se a mãe for uma parceira adequada para o pai (San'hedrin 71a) e apenas se ambos, pai e mãe, são parecidos no que diz respeito à voz, aparência e estatura (Idem). E, além de tudo isso, os sábios concluiram que "um menino só pode ser considerado um filho teimoso e rebelde por um período de três meses de sua vida" (San'hedrin 69a).

\footnotetext{
${ }^{67}$ Curiosamente, o uso do termo masculino se justificaria em hebraico, como em português, por ser ele a forma gramatical usada ao se referir a homens e mulheres em conjunto. Apesar disso, os sábios viram o uso do masculino como um uso específico, referindo-se só aos homens, e não um uso geral e inclusivo, que abarcaria também as mulheres.
} 
5.3. Princípios usados no Midrash

Foi visto anteriormente que a Hilel, considerado o "pai" do midrash, se atribui a formulação de sete princípios por meio dos quais a Torá pode ser interpretada. Esses princípios são métodos de estudo através dos quais (embora não apenas por eles) os sábios da Mishná e do Talmud interpretaram os versículos da Torá e, assim, com suas diferentes aplicações (explicativo, lógico, exemplificador e restritor) estabeleceram as leis que compreendem a halachá.

Segundo a tradição, o Rabi Ishmael, no final do século I e começo do século II, expandiu os sete princípios de Hilel para treze.

O Rabi Ishmael diz: Por meio de treze princípios a Torá é interpretada:

1. Qal vachômer

2. Guezerá Shavá

3. Binian av mi catuv echad, mi binian av mi shenê ketuvim

4. Miclal ufrat

5. Miprat uchlal

6. Miclal ufrat uclal i eta dan ela keain ufrat

7. Mi clal she hu tsarich laprat umifrat she hu tsarich laclal

8. Col davar shehaiá bichlal veiotsê min haclal lelamed lo lelamed al atsmo iatsá, ela lelamed al haclal culo iatsa

9. Col davar shehaia bichlal veiotsê min haclal liton taan achar she huh keinianô iatsá lehakel velo leachmir

10. Col davar shehaia bichlal veiotsê min haclal liton taan achar she lo keinianô 
iatsá lehakel ulehachmir

11. Col davar shehaiá biclal veiotsê min haclal lidon bedavar chadash, i atá iachol leachzir li clalo ad iachzreinu hacatuv liclol be peirush

\title{
12. Davar halamed me inianô vêdavar halamed mi sofô
}

13. Veken shnê ktuvim hamachchishim ze et ze ad sheiavô hakatuv hashlishi veiachria beinehem

(Beraita de Rabi Ishmael, Início do Sifrá) ${ }^{68}$

É importante observar que todas os princípios de Hilel $^{69}$ estão inclusos nos princípios do Rabi Ishmael mas, obviamente, não todos os princípios do Rabi Ishmael são encontrados nos príncipios de Hilel. Se compararmos as duas listas de princípios, veremos que na verdade os princípios de 4 a 11 do Rabi Ishmael estão todos inclusos em um princípio de Hilel (Clal ufrat e prat uchlal - princípio 5), e podem ser entendidas como subdivisões do princípio mais geral de Hilel. O princípio (6) caiotsê bô mimaqom acher (como derivado de outro local) de Hilel está incluso no princípio 3 do Rabi Ishmael.

Lieberman dá uma possível razão para a expansão dos princípios levada a cabo pelo Rabi Ishmael:

\begin{abstract}
Para explicar os textos legais sagrados, que, de modo geral, não estão escritos em linguagem comum e usual, os sacerdotes tinham, sem sombra de dúvidas, outros métodos e princípios. Os sábios utilizavam um pequeno número de princípios do Midrash na parte de leis da Torá. Estas medidas foram resultado de uma escolha, uma diferenciação e um processo de seleção dentre uma multiplicidade de formas de interpretação das Escrituras. Mas no que diz respeito à lenda e à autoridade legislativa, os sábios precisavam dos meios aceitos no mundo literário da época. Estes meios são
\end{abstract}

\footnotetext{
${ }^{68}$ Embora no mundo judaico os princípios do Rabi Ishmael sejam sempre citados em hebraico, ofereço aqui uma tradução literal de cada um dos termos, para que sirva como referência ao leitor: 1 . Leve e pesado; 2 . Decreto similar; 3. Padrão de um trecho das Escrituras, de um padrão de dois trechos das Escrituras; 4. Do geral e particular; 5. Do particular e do geral; 6. O geral, o particular e o geral; 7. O geral que precisa ser explicado pelo particular e o particular que precisa ser explicado pelo geral; 8. Todo particular implícito no geral e derivado dele por motivos pedagógicos elucida o geral e também o particular; 9 . Todo particular implícito no geral e derivado dele por causa de outro regulamento que corresponde conceitualmente ao original foi derivado para tornar mais leniente, e não mais severo, a sua aplicação; 10 . Todo particular implícito no geral e derivado dele por causa de outro regulamento que não corresponde conceitualmente ao original foi derivado para tornar mais leniente ou mais severo a sua aplicação; 11. Todo particular implícito no geral e derivado dele por causa de uma decisão nova e oposta pode ser referenciado ao geral só se a passagem em consideração fizer menção explícita ao geral; 12. Algo derivado do contexto e algo derivado da sua conclusão; 13. Quando ocorrer de duas passagens se contradizerem entre si, uma terceira passagem deve ser usada para resolver a contradição.

${ }^{69}$ Para facilidade de referência, eis os princípios de Hilel: (1) Qal vachômer, (2) Guezerá Shavá, (3) Binian av mi catuv echad, (4) Binian av mi shenê ketuvim, (5) Clal ufrat e prat uchlal, (6) Caiotsê bo mimaqom acher e (7) Davar halamed meinianô.
} 
estes princípios interpretativos artificiais, fruto da inteligência dos próprios sábios. A autoridade deles não era aceita de pronto na religião, e soavam estranhas para as pessoas. Mas como eles utilizavam estes princípios mundialmente aceitos pela cultura da época, os princípios interpretativos da lenda (e da definição da lei com base nas Escrituras) passaram a ser vistos como o esplendor da linaguagem figurada do modo com que era entendida pelas pessoas de sua época e que estava perto do seu coração.

(Lieberman, Ievanit ve Ievanut be Erets Israel, pp. 209-210).

Embora com a apresentação feita aqui obtém-se a impressão de que o Rabi Ishmael era um seguidor dos ensinamentos do Rabi Akiva, o que se sabe é que ambos tinham, na verdade, ideias bastante antagônicas quanto aos modos de interpretar a Torá. Assim, embora ambos usassem de certo modo os mesmos princípios interpretativos, eles não concordavam em pontos básicos de hermenêutica. ${ }^{70}$

\subsubsection{Qal vachômer ${ }^{71}$}

Com o princípio de Qal vachômer, de um assunto A aprende-se a lei sobre outro assunto B se houver evidência de que um dos assuntos é mais leniente do que o assunto a ele relacionado.

Na própria Torá pode-se ver um exemplo desse princípio sendo usado: Eis que devolvemos a ti o dinheiro que encontramos na boca de nossas bolsas, desde a terra de Canaan; e como roubaríamos da casa de teu senhor prata ou ouro? (Gênesis 44:8). Ou seja, no versículo um dos irmãos de José, para se defender da acusação de roubo, usa o princípio de Qal vachômer: se nós devolvemos o dinheiro encontrado dentro das bolsas, Qal vachômer, como roubaríamos da casa de teu senhor prata ou ouro?

Quando usado no âmbito da lei, esse princípio pode promover um aprendizado em duas direções: 1) aprende-se a lei do que é mais severo a partir do que é mais leniente, para considerar mais sério o que é severo; ou, em outras palavras, fortalece-se a gravidade do caso mais sério ou 2) aprende-se a lei do que é mais leniente a partir do que é mais severo, para se considerar menos grave o que é mais leniente; ou, em outras palavras, alivia-se a gravidade do caso que é considerado mais leve.

\footnotetext{
${ }^{70}$ Para conhecer as diferenças metodológicas entre o Rabi Akiva e o Rabi Ishmael, cf. infra, cap. 6 e HESCHEL, p. 56-58; EPSTEIN (1957), pp. 521-536 e MELAMED (1973), pp. 172-180.

${ }^{71}$ Em uma tradução da retórica e lógica latina, este princípio poderia ser chamado de "a minori ad majus" ou "a majori ad minus". Outro nome comum dado a este argumento é "argumento a fortiori”.
} 
Vejamos exemplos dessas duas direções:

5.3.1.1. Decisão do mais severo a partir do que é mais leniente, para agravar o que é mais severo

A Torá especifica as leis relacionadas aos diferentes guardas e vigias de animais vigia voluntário, vigia assalariado, vigia mutuário, etc. - e as suas diferentes responsabilidades conforme as diferentes situações ocorridas com o objeto de sua guarda - perda, roubo, dilaceração, etc. Tratando do vigia assalariado, a Torá diz: Mas se lhe for roubado [o que ele está vigiando], pagará a seu dono (Êxodo 22:11). Por outro lado, se um animal for dado ao vigia assalariado para ser cuidado e o animal morrer, ficar aleijado ou cativo (Êxodo 22:9), ou se lhe for dilacerado (Êxodo 22:12), neste caso, far-se-á um juramento ao Eterno entre ambos [...] e o outro nada pagará (Êxodo 22:10).

Depois de tratar do caso do vigia assalariado, logo em seguida a Torá trata das leis relativas ao vigia mutuário, e, neste caso, determina: E quando um homem pedir [um animal] emprestado de seu companheiro, e este ficar aleijado ou morrer [...] pagará (Êxodo 22:13).

No entanto, a Torá não diz qual é a lei que se aplica ao mutuário se o animal foi roubado ou perdido. Esta lei os sábios derivam usando o princípio de Qal vachômer:

Eu só sei o que fazer com o animal aleijado ou que morreu, mas e o que fazer com o
animal que foi roubado ou perdido? Usamos o princípio de Qal vachômer e, do mesmo
jeito que o vigia assalariado está isento de pagar se o animal ficar aleijado ou morrer,
mas está obrigado se o animal for roubado ou perdido, o vigia que pediu o animal
emprestado, e que já está obrigado em caso de animal aleijado ou morto, também está
obrigado se o animal for roubado ou perdido.

(Baba Metsia 95a)

5.3.1.2. Decisão do mais leniente a partir do que é mais severo, para tornar mais leve o que é mais leniente

A Escola de Shamai e a Escola de Hilel divergem quanto à questão se é permitido 
oferecer o sacrifício de Olá $^{72}$ de um indivíduo em um Iom Tov ${ }^{73}$ (Betsá 82a). A Escola de Hilel tenta provar a sua opinião usando o Qal vachômer:

A Escola de Hilel disse para a Escola de Shamai: Se no Shabat, que a pessoa comum não pode preparar sua comida [pois é proibido cozinhar no Shabat], ela pode oferecer sacrifícios; no Iom Tov, no qual a pessoa pode preparar sua comida, certamente ela também pode oferecer sacrifícios.

(Betsá 20b)

\subsubsection{Limitação do Qal vachômer}

Tendo visto os dois tipos de Qal vachômer, agora veremos que a aplicação dele era pautada por certos princípios e válida apenas em alguns casos. Linguística e logicamente falando, o qal vachômer é composto de duas partes: a parte ou premissa da qual se deriva um ensinamento ou lei - a "fonte" (em hebraico, nadon), e a conclusão obtida do emprego da premissa, o "aprendizado em questão" (em hebraico, ba min hadin). Mais tarde, esses termos foram trocados na literatura rabínica, respectivamente, por melamed (o que ensina) e lamed (o que se aprende).

Na aplicação do Qal vachômer existe um princípio importante que diz: o Qal vachômer se sustenta quando o aprendizado em questão é similar à fonte (Bava Qama 25a, et al.). Isso quer dizer que para aplicar o Qal vachômer de maneira válida, basta que o aprendizado extraído de uma premissa seja similar em gravidade à premissa em si, da qual se está extraindo o ensinamento ou lei. Esta condição, na literatura talmúdica, se chama daiô.

Se, no entanto, a conclusão tirada de uma premissa for mais severa do que a própria premissa, o Qal vachômer é inválido, pois violou a condição de daiô.

Vamos imaginar um exemplo hipotético e depois ver um caso da aplicação do daiô como limitador do Qal vachômer na própria Torá.

Suponha que um pai vai castigar o seu filho se ele entrar em casa com o tênis sujo de lama. Pode-se supor que o pai também vai punir o filho se ele chegar em casa com o tênis sujo de lama, com a calça rasgada e com a camiseta despedaçada. Esse tipo de raciocínio se baseia

\footnotetext{
${ }^{72} \mathrm{O}$ sacrifício de olá devia ser oferecido duas vezes ao dia no Templo, em um ritual feito por um sacerdote. No entanto, pessoas comuns do povo também podiam oferecer o sacrifício em diferentes ocasiões, como: ao final de um voto nazirita, depois da cura de uma doença cutânea, depois do parto (no caso de uma mulher), depois da recuperação após um período de corrimentos, após a conversão de uma pessoa ao judaísmo, ou mesmo como um sacrifício voluntário. É sobre estes casos que a Escola de Shamai e a Escola de Hilel debatem.

${ }^{73}$ Feriados ou festivais judaicos.
} 
na lógica pura: se o pai se irrita a ponto de castigar o filho por causa de um item (o tênis), obviamente o pai vai sentir pelo menos a mesma raiva com outros itens danificados. Esta seria uma aplicação válida do Qal vachômer.

O problema de violação do daiô ocorre se pensarmos do seguinte modo: Se o pai vai dar uma palmada no filho caso ele chegue em casa com o tênis sujo de lama, certamente ele vai dar três palmadas no filho se ele chegar com o tênis sujo de lama, com a calça rasgada e com a camiseta despedaçada.

Embora este pareça um argumento lógico, não o é, justamente por violar o daiô. Ou seja, a conclusão tirada da premissa (o filho receberá três palmadas) foi mais severa do que a premissa em si (o filho receberá uma palmada pelo tênis sujo). Tudo o que podemos inferir logicamente é que o castigo do filho será, no mínimo, de uma palmada.

Se este tópico fosse levado à discussão para definição da lei, os sábios não poderiam dizer, por exemplo, que no primeiro caso o filho merece uma palmada, e no outro o filho merece três.

Na Torá podemos ver um exemplo disso no seguinte caso: E o Eterno disse a Moisés: 'Se seu pai se tivesse zangado com ela, não deveria ela ficar envergonhada por sete dias?' (Números 12:14).

Esse trecho se refere a Miriam, que falou mal de Moisés junto a Aharão por conta de seu casamento com uma mulher negra. No episódio, Deus se irrita e Miriam é acometida pela lepra. Moisés reza a Deus para que sua irmã seja curada e Deus responde com o versículo trazido acima, que significa: se ela tivesse irritado o pai dela, ela não teria ficado envergonhada por sete dias?

Então, pela lógica, no caso em que ela irritou ao próprio Deus, poderíamos supor que ela deveria ficar envergonhada (e, portanto, sofrendo com a praga) por pelo menos o dobro do tempo, ou seja, catorze dias, digamos. Essa seria uma dedução por Qal vachômer.

No entanto, este seria um Qal vachômer inválido, pois a conclusão terminaria sendo mais severa do que a premissa, e teria violado, portanto, o daiô. Justamente por isso a decisão final do versículo é: que ela seja encerrada sete dias fora do acampamento, e depois recolhida (Números 12:14). Ou seja, mesmo que Miriam tenha irritado a Deus, a punição aplicada a ela é a mesma que se ela tivesse irritado ao seu pai. O motivo para isso é explicado no Sifri:

Se com seu pai de carne e osso o castigo é de sete dias, no caso de Deus dever-se-ia aplicar um castigo de catorze dias. Mas isso faria com que o "aprendizado em questão" fosse mais severo do que a "fonte"; portanto, do mesmo jeito que com o pai de carne e osso ela é castigada por sete dias, com Deus, ela também é castigada por sete dias. 


\title{
5.3.1.4. Anulação do Qal vachômer
}

Quando os sábios descobriam esse tipo de engano e falácia no uso do Qal vachômer pelos seus companheiros, ou seja, quando detectavam a violação do princípio de daiô, eles refutavam a aplicação deste princípio para determinar a lei. Qualquer refutação e anulação de um qal vachômer se chama pircá (refutação) na terminologia dos sábios amoraítas, redatores do Talmud.

Outra maneira de anular o Qal vachômer (de estabelecer uma pircá) é provar que o assunto trazido como leniente não o é, por conter algo de severo. Se isso fica provado, os dois assuntos comparados têm o mesmo grau de severidade e, portanto, não se pode tirar a lição de um deles para aplicar no outro.

A pircá também pode ocorrer da maneira oposta, quando o assunto que se considera severo não o é, por conter algo que o defina como leniente.

Vejamos um exemplo:

Pela lei judaica, é preciso oferecer o sacrifício pascal (sacrifício de Pêssach) durante a festa de Pêssach. No entanto, às vezes a véspera de Pêssach cai no Shabat, um dia em que algumas atividades são proibidas e, portanto, surgiu a dúvida sobre se é permitido oferecer o sacrifício pascal no Shabat ou não. Para tentar definir a lei, Hilel aplica o princípio de Qal vachômer:

\begin{abstract}
Se com o sacrifício de tamid, ${ }^{74}$ ao qual não se aplica a pena de carêt (excomunhão) caso ele não seja oferecido, o Shabat não é considerado; com relação ao sacrifício de Pêssach, que deve ser feito sob pena de carêt, obviamente o Shabat não deve ser considerado.
\end{abstract}

(TJ, Pessachim, 6:1, 33a)

Ou seja, a lógica de Hilel é a seguinte: deve-se oferecer o sacrifício de tamid no Shabat, mesmo sabendo que ele é menos "severo" do que o sacrifício de Pêssach, pois o homem que não oferece esse último pode ser punido com carêt, mas quem não oferece aquele não recebe pena alguma. Portanto, para Hilel, se o sacrifício de tamid, que é menos severo do que o de

\footnotetext{
${ }^{74}$ Lit. "constante”. Um sacrifício oferecido diariamente no Templo, mesmo no Shabat.
} 
Pêssach, pode ser oferecido no Shabat, o mesmo se aplica ao sacrifício de Pêssach.

No entanto, é interessante notar que a aplicação do princípio de Qal vachômer por Hilel nesse caso sofre uma pircá (refutação) por parte dos outros sábios: $o$ Qal vachômer que você usou tem uma refutação. Você se esqueceu de dizer que o sacrifício de tamid [diário] é considerado santidade das santidades, mas o sacrifício de Pêssach é considerado de santidade leve (Idem).

Ou seja, com relação à punição por não oferecer cada um dos sacrifícios, de fato, o sacrifício de Pêssach é mais severo do que o sacrifício de tamid, no entanto, por outro ponto de vista, este último é mais severo pois é considerado "santidade das santidades" (o grau mais alto de santidade de um sacrifício); já o sacrifício de Pêssach é considerado apenas "santidade leve" (de um nível de santidade inferior). Assim, como o sacrifício de tamid possui um lado de severidade que não foi levado em consideração no Qal vachômer, o princípio fica invalidado.

\subsubsection{Guezerá shavá}

Diversos sábios e pesquisadores debateram acerca do significado e da utilização deste princípio, por ser ele um dos mais "polêmicos" (Cf., por exemplo, LIEBERMAN, 1984, pp. 194-195 e GUILAT, 1984, pp. 88-91). De modo geral, a definição mais aceita desse princípio é que ele serve para definir uma lei sobre um assunto partindo de outro assunto, basedo em palavras iguais ou similares usadas pela Torá ao descrever ambos os assuntos.

A grande diferença deste princípio para o anterior é que ele não se baseia necessariamente na lógica, na razão e no senso comum, mas apenas na semelhança lexical entre duas passagens da Torá e esse é justamente o ponto polêmico por trás dele. Para os sábios, o fato de a mesma palavra ter sido usada em dois contextos distintos da Torá é evidência suficiente de que os dois assuntos tratados estão interconectados e, portanto, suas leis são relacionadas.

Por exemplo, a expressão "e destroncará a cabeça" (מלק את ראשו, malac et roshô) aparece apenas duas vezes na Torá, a primeira em Levítico 1:15 e a segunda em Levítico 5:8. No segundo caso, no entanto, existe uma explicação adicional adjunta à expressão: “os trará ao sacerdote, que oferecerá primeiro o que é por sacrifício de pecado, e destroncará sua cabeça pela nuca, porém não os separará”. Assim, o Midrash (Sifra 9a) conclui que a explicação adicional "pela nuca" é parte definitória do conceito de "destroncar a cabeça" e que, no primeiro 
caso (de Levítico 1:15) também se deve aplicar um destroncamento pela nuca.

Outro exemplo, talvez dos mais famosos, diz respeito às leis do Shabat. Na Torá está escrito: Vede que o Eterno vos deu o Shabat, portanto ele vos dá pão para dois dias na sextafeira. Ficai cada um em seu lugar; que ninguém saia de seu lugar no sétimo dia (Êxodo 16:29).

O texto especifica claramente que as pessoas devem "ficar em seu lugar" e que não devem "sair do seu lugar" no dia de Shabat. No Midrash surge, então, a questão de qual é o limite que uma pessoa pode caminhar no dia de Shabat para não violar o mandamento que determina que ninguém saia de seu lugar. O versículo é explicado da seguinte maneira:

\footnotetext{
Que ninguém saia de seu lugar. O sair ocorre aos 2.000 cúbitos. ${ }^{75}$ Você diz que são 2.000 cúbitos, mas por que não 4 cúbitos? A decisão vem do seguinte fato, aqui está escrito "lugar", e em outro local [em Êxodo 21:13, relacionado às cidades-refúgio] está escrito "lugar". Do mesmo jeito que lá "lugar" se trata de 2.000 cúbitos, aqui "lugar" se trata de 2.000 cúbitos.

(Mechilta de Rabi Ishmael, Nezikin, 4)
}

O mero fato de dois trechos da Torá terem usado a palavra "lugar" é usado como evidência para definir a lei. Repare que neste caso não existe processo lógico ou racional, como ocorria com o Qal vachômer.

Outro exemplo de uso da guezerá shavá pode se ver no caso já mencionado do escravo que serviu por seis anos e que será libertado no sétimo ano. A Torá diz que se o escravo porventura não desejar ser libertado neste ano, deve-se furar a sua orelha, como um sinal de que o escravo voluntariamente optou por continuar servindo ao seu amo. A pergunta que os sábios do Talmud fazem é: qual orelha deve ser furada, a direita ou a esquerda?

O Rabi Eliezer diz: De onde sabemos que se deve furar a orelha direita? Do fato de que aqui está dito "orelha" (Êxodo 21:6) e em outro local (Levítico 14:14, a respeito da lepra) está dito "orelha". Do mesmo jeito que lá "orelha" alude à direita, aqui também "orelha" alude à direita.

(Kidushin, 15a)

\subsubsection{Restrições da Guezerá shavá}

Como o princípio de guezerá shavá não é um princípio que usa a lógica para

\footnotetext{
${ }^{75} \mathrm{O}$ cúbito, amá, é uma medida bíblica que varia de 48 a 57,6 cm, dependendo da autoridade.
} 
estabelecer a lei, começou a surgir o temor de que as leis formadas com base nesse princípio, puramente lexical, fossem absurdas e inválidas. Para evitar isso, os sábios definiram limitações para a aplicação válida deste princípio. São elas:

a) Não se aprende da guezerá shavá se ela não for "livre" - isso significa que a palavra do texto usado como base para a comparação lexical deve ser "livre", ou seja, deve ser uma palavra supérflua e não-essencial. Este princípio foi estabelecido pelo Rabi Ishmael (Nidá 22b), mas alguns sábios, como o Rabi Akiva, discordam dele, dizendo que mesmo que as palavras sejam essenciais e centrais ao texto, podem ser usadas para guezerá shavá.

b) Ninguém pode definir uma lei por guezerá shavá por conta própria (Pessachim 66a). A isso, o Rashi acrescenta: "a não ser que tenha aprendido a lei de seu mestre”. Ou seja, se o aluno já conhecia a lei, por tê-la aprendido com seu mestre, e se ele quisesse explicála usando a guezerá shavá, ele podia; caso contrário, não. Ou seja, essa limitação vem para tentar impedir que se criem novas leis que não têm base ou fundamente na tradição.

\subsubsection{Binian av}

Binian Av pode ser entendido como "padrão". Os sábios usam uma ou duas passagens das Escrituras como chave interpretativa para outras passagens.

\subsubsection{Binian av Micatuv Echad}

Este princípio consiste em usar uma passagem das Escrituras como padrão para interpretar diversas outras passagens. Por exemplo, um trecho do Pentateuco diz: Não valerá uma testemunha contra um homem [...] pela boca de duas testemunhas, ou pela boca de três testemunhas, se afirmará a causa (Deuteronômio 19:15). Daqui, os sábios entenderam:

Se o versículo dissesse "não valerá testemunha contra um homem" eu já não saberia que se trata de uma? Por que foi necessário usar a palavra "uma"? Isso estabelece um padrão [baná av], de que em todo lugar em que se diz "testemunha" [sem o artigo, ainda que seja no singular], são necessárias duas testemunhas, a não ser que a Escritura 
diga explicitamente "uma testemunha" [com o numeral].

(San'hedrin 30a)

5.3.3.2. Binian av Mishenê Ketuvim ${ }^{76}$

Este princípio é similar ao anterior, mas em vez de apenas uma passagem ser usada para estabelecer um padrão, dois versículos são usados. Por exemplo: Quando entrares na vinha de teu companheiro, poderás comer uvas conforme teu desejo, até te fartares, porém não porás na tua bolsa (Deuteronômio 23:25). Logo em seguida o próximo versículo diz: Quando entrares na seara de teu companheiro, poderás colher espigas com a tua mão (Deuteronômio 23:26). No Midrash de Halachá (Sifri Devarim, 266-267), os sábios deduzem que os dois versículos se aplicam a um trabalhador no campo de seu dono. E, por extensão, eles deduzem que isso se aplica a qualquer trabalhador rural, não necessariamente trabalhando em uma vinha ou seara. A lei no Talmud é definida assim:

O que os dois versículos têm em comum? Ambos tratam de coisas que nascem do solo e aludem ao momento em que o trabalhador cessou de trabalhar e deseja comer. Portanto, tudo que nasce do campo pode ser comido pelo trabalhador quando ele cessa seu trabalho.

(Bava Metsia, 87b)

Os sábios encontraram duas coisas em comum entre os dois versículos: ambos falam de produtos da terra (vinha e seara) e ambos se referem ao fim do trabalho. Portanto, sempre que essas duas condições se verificam, estabelece-se um padrão, e o trabalhador pode comer o produto em questão.

\subsubsection{Clal ufrat}

Este princípio é, na verdade, composto por quatro subtipos: clal ufrat, prat uchlal, clal

\footnotetext{
${ }^{76}$ Meir Alon (1988, pp. 300-302) lista dois princípios adicionais: Binian av Mishalosh Ketuvim e Mearba Ketuvim (de três e de quatro passagens bíblicas)
} 
ufrat uclal, clal shehu tsarich leparet ufrat shehu tsarich lichlal. No entanto, o problema por trás de todos eles é o mesmo: em algumas definições da halachá, a Torá traz citações e termos duplos, ou seja, o mesmo trecho, traz um ensinamento geral e um ensinamento específico, sendo que o específico já está incluso no geral. Então, a pergunta é: para que essa dupla menção das coisas? Para que trazer o caso geral e o caso particular lado a lado?

\subsubsection{Clal ufrat}

Fala aos filhos de Israel e diz-lhes: Quando algum de vós oferecer sacrifício ao Eterno, fareis vosso sacrifício de animal, de animal do gado e do rebanho (Levítico 1:2).

Esse versículo começa dando uma instrução geral (os sacrifícios devem ser de animais) e em seguida aparecem os detalhes, animais que sejam do gado ou do rebanho; detalhes esses que já estão inclusos na instrução geral. Como o detalhe (prat) aparece depois do princípio geral ( clal), deduz-se que, pelo texto, só é possível sacrificar animais do gado e do rebanho, e não qualquer tipo de animal que se deseje. O Midrash explica isso da seguinte maneira:

\footnotetext{
Aprendemos isso do clal ufrat. Como? "De animal" é o clal (geral), "do gado" e "do rebanho" são o prat (detalhe). Sempre que temos um clal e em seguida um prat, a lei não é com o que está no clal, mas com o que está no prat.

(Beraita de Rabi Ishmael, início do Sifra)
}

Ou seja, os sábios definiram que, nesses casos, o prat vem apenas para restringir e especificar o clal, e que a lei se aplica conforme ao prat.

\subsubsection{Prat uchlal}

Este princípio é similar ao anterior, sendo a única diferença a ordem dos ensinamentos. Aqui os detalhes são trazidos primeiro e depois vem a instrução geral, que inclui os detalhes.

Com respeito às leis dos vigias, o texto bíblico diz: Quando um homem der a seu companheiro um asno, boi, carneiro ou qualquer animal para guardar, e este morrer, ficar aleijado ou cativo, e não houver testemunhas [...] (Êxodo 22:9). “Asno”, "boi” e "carneiro" são 
detalhes (pratim), e logo em seguida o texto traz o princípio geral (clal) "qualquer animal". Portanto, o asno, o boi e o carneiro estão inclusos no conjunto de "qualquer animal". Sobre isso, os sábios dizem:

\footnotetext{
Aprendemos algo do prat uchlal. Como? Quando um homem der a seu companheiro um asno, boi, carneiro é o prat (detalhe), e "qualquer animal para guardar" é o clal (geral). Sempre que temos um prat e em seguida um clal, fazemos o clal, que é um acréscimo ao prat.
}

(Beraita de Rabi Ishmael, início do Sifra)

Nesses casos os sábios determinaram que "prat uchlal - faz-se o clal, que é um acréscimo para o prat". Ou seja, os detalhes vêm apenas para exemplificar o que é trazido no princípio geral, e a lei se aplica conforme o geral.

\subsubsection{Clal ufrat uchlal}

Nesse princípio o versículo aparece composto por dois princípios gerais, um no começo e outro no final do versículo. Entre eles aparecem os detalhes, que estão inclusos nos dois princípios gerais.

De outro modo, esse princípio pode ser entendido como um "misto" dos dois princípios anteriores. Na primeira parte temos um clal ufrat, e, do outro lado, temos um prat uchlal.

Os sábios estabeleceram o princípio de que quando há um clal ufrat uclal, a Torá não quer incluir tudo o que está trazido nos princípios gerais (como no caso do prat uchlal), mas ela também não deseja que se usem apenas os detalhes (como no caso do clal ufrat). A Torá estaria se referindo a tudo aquilo que é do grupo geral, mas que é "como o detalhe", ou seja, tudo aquilo que se assemelha em forma ou conteúdo aos detalhes explicitados.

Por exemplo, pela Torá, um ladrão que foi pego roubando em flagrante, ou um vigia que foi pego roubando o que ele deveria vigiar, deve pagar uma compensação equivalente ao dobro do que foi roubado. E sobre isso a Torá ordena: Sobre toda coisa de delito - sobre boi, asno, cordeiro, roupas ou qualquer coisa perdida em que houver qualquer contestação - a causa de ambos virá aos juízes; e aquele a quem os juízes condenarem pagará o dobro a seu companheiro (Êxodo 22:8). Os sábios explicam o versículo deste modo: 
Os sábios ensinaram: "Sobre toda coisa de delito" é o clal (geral). "Sobre boi, asno, cordeiro, roupas" é o prat (detalhe). "Qualquer coisa perdida em que houver qualquer contestação" voltou a trazer o clal. Clal ufrat uchlal, julga-se conforme o prat. Do mesmo modo que o prat explicita bens móveis ou bens financeiros, assim isso vale para tudo aquilo que é móvel ou que tem valor financeiro. Saíram (do clal) terrenos, que não são bens móveis. Saíram (do clal) os servos, que são considerados como parte do terreno. Saíram (do clal) as notas promissórias, pois embora sejam bens móveis, não têm valor financeiro.

(Bava Qama, 62b)

\subsubsection{Clal shehu tsarich leparet ufrat shehu tsarich lichlal}

Nesse último princípio há um detalhe que vem para esclarecer o que é geral ou uma definição geral que vem elucidar os detalhes. Ou seja, nesse caso o princípio geral trazido não é claro por si só, e ele exige uma explicação mais detalhada, função essa preenchida pelo prat. Nos casos anteriores, o clal era claro por si só e não precisava de detalhes que o explicassem. Assim, os detalhes pareciam redundantes, e eram apenas casos particulares que vinham restringir o geral, mas não elucidá-lo. Aqui, pelo contrário, o detalhe não vem para limitar e especificar o clal, mas sim para explicá-lo, pois sem ele a lei não pode ser entendida.

Na Torá está dito: Consagra para Mim todo primogênito - todo aquele que abrir a matriz de sua mãe - entre os filhos de Israel, no homem e no animal; porque é Meu. (Êxodo 13:2). E no livro de Deuteronômio consta: Todo primogênito macho que nascer de teu gado e de teu rebanho consagrarás ao Eterno, teu Deus; não farás nenhum serviço com o primogênito de teu boi, nem tosquiarás o primogênito do teu rebanho (Deuteronômio 15:19).

Os dois versículos tratam da santidade dos primogênitos, ou daquilo que surge primeiro. Vejamos o que diz o Midrash sobre isso:

\footnotetext{
"Consagra para Mim todo primogênito" poderia dar a entender que isso inclui as fêmeas. Então o versículo veio e disse "macho". Mas então podemos pensar que o macho é consagrado mesmo quando primeiramente nasceu uma fêmea. Então o versículo veio e disse "todo aquele que abrir a matriz de sua mãe". Mas então podemos pensar que aquele que abriu a matriz de sua mãe é consagrado mesmo que tenha nascido depois de um bebê que nasceu por meios não-convencionais. Então o versículo veio e disse "primogênito". Trata-se de um clal que precisa de um prat, e de um prat que precisa de um clal.
} 
Da junção de ambos os versículos vemos o uso do princípio geral "todo primogênito", e de dois detalhes: "todo aquele que abrir a matriz de sua mãe", e "macho". Se apenas o princípio geral fosse considerado, poder-se-ia pensar que o primogênito inclui tanto os machos como as fêmeas, e que ambos possuem a santidade especial do primogênito. Mas então é trazido o detalhe "macho", o que explica que o primogênito só pode ser macho.

Em seguida, então, poder-se-ia pensar que qualquer primogênito macho recebe esta santidade, ou seja, o primeiro macho a nascer, mesmo que antes dele tenha nascido uma fêmea. O detalhe "todo aquele que abrir a matriz de sua mãe" explica que não, que é preciso que o macho que nasceu seja de fato a primeira cria.

Por fim, poder-se-ia pensar que se primeiro nasceu uma criança "por meios nãoconvencionais", como uma cesárea, por exemplo (que não é um "abrir da matriz de sua mãe") e depois um macho pelas vias naturais, por parto normal, ele receberia a santidade do primogênito. Nesse caso, o princípio geral, "primogênito", explicita que necessariamente ele precisa ser o primeiro a nascer, e o segundo já não vale.

Portanto, da combinação de todos os detalhes dos dois versículos, estabeleceu-se que a santidade especial se aplica somente a todo primogênito macho que nasceu de parto natural.

\subsubsection{Davar halamed meinianô}

Esse princípio possui duas formas, construídas da seguinte maneira: quando a Torá apresenta um assunto que é críptico, pouco claro, tenta-se entender mais sobre o assunto por meio da continuação do texto ligado àquele mesmo assunto (davar halamêd mesofô), ou por meio da relação entre assuntos próximos ao assunto críptico (davar halamêd meinianô), uma espécie de contexto.

\subsubsection{Davar halamed meinianô}

Na Torá existem duas menções à proibição de roubo: não roubarás (como consta nos Dez Mandamentos, Êxodo 20:15 e Deuteronômio 5:17) e não roubareis (Levítico 19:11).

Os sábios entenderam que se trata de dois tipos de roubo diferentes. O primeiro caso é 
o roubo de pessoas, isto é, sequestro, e o segundo é o roubo de dinheiro.

\begin{abstract}
Os sábios ensinaram: "Não roubarás" se refere ao roubo de seres humanos. Você diz que o texto se refere ao roubo de seres humanos, mas talvez não seja isso. Será que não se trata do roubo de dinheiro? Eu te digo: Sai e aprende dos treze princípios por meio dos quais a Torá é interpretada. Davar halamêd meinianô [a lei sobre um caso é aprendida pelo seu contexto]. De que o texto está falando? De um crime capital, então aqui também se trata de um crime capital. Outro Sábio ensinou: "Não roubareis" se refere ao roubo de dinheiro. Tu dizes que o texto se refere ao roubo de dinheiro, mas talvez não seja isso. Será que não se trata do roubo de pessoas? Eu te digo: Sai e aprende dos treze princípios por meio dos quais a Torá é interpretada. Davar halamêd meinianô [a lei sobre um caso é aprendida pelo seu contexto]. Do que o texto está falando? De assuntos financeiros, então aqui também se trata de dinheiro.
\end{abstract}

(San'hedrin 86a)

\title{
5.3.5.2. Davar halamêd mesofô
}

Aqui as leis são aprendidas por meio da continuação das palavras ligadas a um certo assunto, ou seja, à parte obscura do assunto. É preciso salientar, no entanto, que a expressão "sofô" (seu final), aqui, não alude necessariamente ao fim do assunto, mas a uma outra parte do assunto. Há casos em que esse princípio foi usado para explicar um trecho obscuro com o início de outro trecho, mais claro.

A Torá diz: E o Eterno disse a Moisés: Fala a Aarão, teu irmão, que não venha a toda hora à santidade, para dentro da divisória, diante do tampo que está sobre a arca, para que não morra, pois com uma nuvem aparecerei sobre o tampo. Com isto virá Aarão à santidade: com um novilho por oferta de pecado e um carneiro por oferta de elevação. Vestirá túnica sagrada de linho e calções de linho terá sobre sua carne. (Levítico 16:2-4).

Esses versículos deixam claro que Aarão não pode entrar no Santo dos Santos a qualquer momento, como bem deseja. Em seguida, a Torá determina que Aarão só pode entrar se oferecer certos tipos de sacrifícios e se usar um certo tipo de roupa, a roupa do sacerdócio. Portanto, aparentemente, sempre que Aarão usar a roupa especial e oferecer os sacrifícios mencionados no trecho, ele pode entrar no Santo dos Santos. No entanto, mais adiante o mesmo trecho diz: E isso será para vós por estatuto perpétuo; no $7^{\circ}$ mês, no dia 10 do mês, afligireis as vossas almas [...] porque nesse dia se fará expiação por vós, para purificar-vos de todos vossos pecados [...] e isso será para vós por estatuto perpétuo, para fazer expiação pelos filhos de Israel por todos os seus pecados, uma vez no ano (Levítico 16:29-34). 
Ou seja, nesse caso os sábios aprenderam do fim do trecho que todo excerto trata somente da entrada de Aarão no Santo dos Santos no dia do Iom Kipur (dia 10 do sétimo mês). É só nesse dia, uma vez ao ano, que Aarão pode entrar em tal recinto.

\subsubsection{Shnê ktuvim hamachchishim ze et ze}

Quando dois versículos parecem ser contraditórios entre si, deve-se procurar na Torá, segundo a regra dos sábios, outros locais onde o assunto em pauta é discutido, e, com base nesses locais, achar a solução para explicar a contradição entre os versículos. Vejamos um exemplo ligado ao sacrifício de Pêssach:

1. Dos carneiros e das cabras haveis de tomá-lo (Êxodo 12:5).

2. Do rebanho e do gado, o Pêssach ao Eterno (Deuteronômio 16:2).

Do primeiro versículo, a lei seria de que o sacrifício de Pêssach pode ser oferecido apenas do que é rebanho (carneiros e cabras). Mas do segundo versículo depreende-se que também é possível utilizar o gado para o sacrifício. Como os dois versículos contraditórios entre si (Shnê ktuvim hamachchishim ze et ze) foram conciliados? Por meio de um terceiro versículo: E Moisés chamou a todos os anciãos de Israel, e disse-lhes: Tirai do rebanho ou comprai um cordeiro para as vossas famílias, e sacrificai para o Pêssach (Êxodo 12:21). Ou seja, apenas animais do rebanho podem ser usados nesse sacrifício, e o termo "gado", que aparece no versículo de Deuteronômio, não se refere a esse sacrifício, no entender dos sábios, mas sim ao sacrifício de Chaguigá, que também é ofertado na festa de Pêssach.

No entanto, às vezes não há um terceiro versículo que concilie os outros dois. Quando isso ocorre, a conciliação vem da lógica dos sábios. Por exemplo:

(4) E os terrenos baldios das cidades que dareis aos levitas, desde o muro da cidade e para fora, serão de mil cúbitos em redor. (5) E medireis de fora da cidade dois mil cúbitos da parte do oriente, dois mil cúbitos da parte do sul, dois mil cúbitos da parte do poente e dois mil cúbitos da parte do norte, tendo a cidade em seu meio; os terrenos baldios das cidades serão para eles.

(Números 35:4-5)

O versículo define os limites ao redor das cidades que devem ser demarcados para 
serem doados aos levitas. Entre o versículo 4 - que fala de mil cúbitos - e o versículo 5 - que fala de dois mil cúbitos, existe uma contradição.

\begin{abstract}
Naquele dia o Rabi Akiva explicou: "E medireis de fora da cidade dois mil cúbitos da parte do oriente" (Números 35:5). Mas outro texto diz: "desde o muro da cidade e para fora, serão de mil cúbitos em redor" (Números 35:4). É impossível dizer que eram mil cúbitos pois já foi dito dois mil cúbitos; e é impossível dizer que eram dois mil cúbitos, pois já foi dito mil cúbitos. Como isso era feito, então? Mil cúbitos de campo aberto para o gado, e dois mil cúbitos para os limites de Shabat. O Rabi Eliezer, filho do Rabi Iossi, o Galileu, disse: mil cúbitos de campo aberto para o gado e dois mil cúbitos para os campos e vinhedos.
\end{abstract}

(Sotá, Capítulo 5, Mishná 3)

O Rabi Akiva resolve a contradição entre os dois versículos afirmando que o versículo 4 se refere ao campo dado aos levitas para criação do gado, e que o versículo 5 se refere aos limites do dia de Shabat, que são sempre de dois mil cúbitos a partir do fim da cidade. Vê-se que aqui o Rabi Akiva não usou um terceiro versículo para definir a lei, mas sim a sua própria lógica. Justamente por isso, por sua ideia não se basear em outro versículo da Torá, o Rabi Eliezer, filho do Rabi Iossi, o Galileu, também aplica a sua lógica para a resolução da contradição. Segundo ele, dois mil cúbitos eram dados aos levitas, e, destes, mil eram para o gado e dois mil eram para campos e vinhedos. 



\section{DIVERGÊNCIAS NO USO DO MIDRASH}

Embora os treze princípios exegéticos fossem amplamente conhecidos e usados pelos sábios, isso não significa que havia uma hegemonia quanto à aplicação desses princípios e os modos como eles deviam ser encarados. Assim, apesar de o midrash ser um método exegético muito utlizado para definir a lei, diferentes casas de estudo, seguindo os ensinamentos do seu mestre, acabaram por divergir quanto ao seu emprego.

Quiçá o caso mais clássico disso é a divergência que se deu entre o Rabi Akiva e o Rabi Ishmael.

O Rabi Akiva, que, segundo o Talmud, derivava a lei inclusive dos adornos nas letras do texto (Menachot 29b), defendia que a Torá, como livro divino, não tinha palavras escritas de maneira desnecessária ou que fossem supérfluas. Os trechos que por algum motivo pareciam ser repetitivos, desnecessários ou redundantes estavam ali para ensinar alguma coisa com relação à lei.

Já o Rabi Ishmael, embora não negasse a divindade da Torá, afirmava que, como ela se destinava aos seres humanos, foi escrita em linguagem humana (Sifri Bamidbar 112). Assim, do mesmo jeito que a fala humana é cheia de repetições, reiterações e redundâncias, o mesmo ocorre no texto da Torá. Portanto, nem todas as palavras e expressões da Torá devem ser levadas em conta na hora de definir a lei.

Sendo assim, expressões como "se pelo resgate não for resgatada" (Levítico 19:20) ou "nem cozida por cozimento na água" (Êxodo 12:9) não devem ser consideradas especiais para a definição da lei, segundo o Rabi Ishmael. Já para o Rabi Akiva, justamente o fato de aparecerem repetições (aparentemente) desnecessárias é o que vem ensinar um ponto sobre a aplicação da lei. Com relação ao segundo versículo, por exemplo, o Rabi Akiva diz: Não se trata só de água, mas de qualquer líquido. Por isso o versículo disse “cozida por cozimento”, para incluir qualquer tipo de líquido (Mechilta de Rabi Ishmael, Pischa, Vav).

Por conta de sua visão de hermenêutica, o Rabi Akiva chegava a empregar o midrash para analisar conectivos e preposições e assim definir a lei; algo que já não ocorre com o Rabi Ishmael, que não via os conectivos como palavras especiais na definição legal. 


\subsection{Permissão ou obrigação}

Um dos pontos de divergência entre o Rabi Akiva e o Rabi Ishmael é que aquele via em todas as frases da Torá uma obrigação; já este via nelas, em alguns casos, um fato concreto, uma obrigação; e, em alguns casos, uma possibilidade, mas não necessariamente uma obrigação.

"Quando ficar com ciúmes de sua esposa" - isso é voluntário [condicional, pode ou não ser feito], segundo o Rabi Ishmael. Mas, o Rabi Akiva diz: é obrigatório (Sotá 3a). ${ }^{77}$

O trecho do Talmud discute o caso do homem que suspeita de que sua esposa o esteja traindo, e a questão de submetê-la ao ritual das "águas amargas"78. Segundo o Rabi Ishmael, a questão deve ser decidida pelo marido. Isso é, se ele quiser, ele pode submeter a mulher àquela prova; mas, caso ele não queira, ele não precisa. Por outro lado, o Rabi Akiva diz que isso é obrigatório. Ou seja, assim que o marido suspeita de que sua mulher o trai, independentemente se quer ou não, ele deve levá-la ao sacerdote para beber das águas amargas e, assim, resolver a suspeita.

Disputa similar ocorre entre os dois sábios com respeito à palavra "se" na Torá. O Rabi Ishmael explica que o "se" sempre instaura o reino da possibilidade, e que a Torá está dando permissão para que a pessoa escolha o que quer fazer. No entanto, o Rabi Akiva explica que todo "se" da Torá é uma obrigação. Por exemplo, no versículo Se seu senhor lhe der uma mulher (Êxodo 21:4), o Rabi Ishmael explica que essa é uma possibilidade, e que o senhor pode dar uma mulher ao seu escravo, se assim o quiser. O Rabi Akiva, no entanto, diz que é obrigatório, e todo aquele que compra um escravo deve lhe dar uma esposa.

6.2. Trecho que volta a ser repetido

\footnotetext{
77 Sotá é o tratado do Talmud que se debruça sobre os rituais envolvendo a fala, em especial o chamado Sotá - que consistia em fazer uma mulher suspeita de adultério beber águas amargas. Caso ela fosse inocente, as águas lhe serviam como bênção. Caso contrário, as águas tinham um efeito fatal.

78 Cf. Números 5:11-31.
} 
A Escola do Rabi Ishmael seguia um princípio: Todo trecho que é enunciado e depois volta a ser repetido só o é para ensinar sobre algo novo (Sotá 3a). Ou seja, um assunto que volta a aparecer na Torá, além da sua primeira aparição, sempre vem para ensinar algo a mais, que não pode ser aprendido do primeiro caso. Assim, por exemplo, um trecho do Êxodo diz: olho por olho, dente por dente, mão por mão, pé por pé, queimadura por queimadura, ferida por ferida, contusão por contusão (Êxodo 21:24-25). No mesmo capítulo, consta: E quando homens brigarem e um homem ferir a seu próximo com uma pedra ou com o punho, e este não morrer, e ficar de cama - se ele se levantar e andar pela rua por sua própria força, aquele que o feriu estará livre; somente lhe dará o dinheiro pelo tempo que perdeu e pela paga de sua cura (Êxodo 21:18-19). Daqui surgiu uma pergunta: por que a Torá aborda duas vezes o mesmo caso? Ambos os casos tratam do dano feito a alguém. Se o primeiro trecho trazido aqui já estabelece um princípio geral (“olho por olho”), por que foi necessário o segundo trecho? Eis o que está escrito na Mechilta de Rabi Ishmael:

"E quando homens brigarem". Para que este trecho foi trazido se já foi dito "olho por
olho"? Porque o versículo anterior não nos ensina nada sobre o repouso e a cura, e é
isso que veio ensinar o versículo "e quando homens brigarem". "Se ele se levantar"
[mostra que] o texto veio ensinar sobre as coisas que faltam no outro versículo. (Mechilta de Rabi Ishmael, Nezikin, 6)

Ou seja, do versículo olho por olho pode-se aprender sobre os pagamentos de danos causados, mas não que o causador do dano deve pagar à parte lesada também os custos de repouso e de cura. Para isso, para ensinar sobre essas lacunas é que o texto teria trazido o segundo versículo.

Segundo o Rabi Akiva, o princípio que rege um trecho repetido é o mesmo de toda a Torá, ele precisa ser interpretado por meio de alguma forma de midrash.

\subsection{A diferença no uso do midrash e suas consequências}

Desses breves exemplos pode-se ver que o Rabi Akiva e o Rabi Ishmael frequentemente discordavam a respeito da maneira de apreender as leis da Torá. Eles são as figuras mais simbólicas dessa disputa, mas o fato se repete com diversos outros sábios e escolas ao longo do tempo. De certo modo podemos dizer que o Rabi Akiva e o Rabi Ishmael foram 
precursores de dois modos diferentes de relação com o midrash e o estabelecimento da lei.

Sem sombra de dúvida, e sem exagero algum, pode-se dizer que os métodos de estudo desenvolvidos tradicionalmente pelo Rabi Akiva permitiram que o midrash se expandisse e desenvolvesse ainda mais, e passasse a ser usado para definir a legislação dos versículos da Torá, segundo as diferentes interpretações e de uma maneira um tanto quanto subjetiva e particular. Por outro lado, o Rabi Ishmael acredita que a lei só devia ser estabelecida baseada no senso comum e usando a lógica adequada e mais racional possível; ou seja, se os métodos do midrash resultassem em conclusões razoáveis.

Um exemplo ilustrativo e talvez extremo dessa divergência e suas consequências pode ser encontrado no julgamento do caso da filha de um sacerdote que se desviou do caminho de santidade. A Torá ordena: E quando a filha desposada do sacerdote se profanar pela prostituição, à honra de seu pai ela profana, e será queimada no fogo (Êxodo 21:9).

O versículo deixa claro que se trata da filha de um sacerdote que era casada e que, justamente por ser ela filha de um sacerdote, o seu pecado é grave, devendo ser punido com morte pelo fogo; ao contrário da mulher que se prostituiu mas que não era filha de um sacerdote, e que sofre morte por estrangulamento (considerado, pelos rabinos, uma pena mais branda do que a morte pelo fogo).

O Rabi Ishmael é da opinião de que esse versículo trata apenas da filha do sacerdote que era noiva (consagrada ao marido), mas não estava casada ainda. Para ele, no caso de a filha já estar casada, a sua lei é como a das outras mulheres, sendo passível de estrangulamento em caso de prostituição.

O Rabi Akiva, no entanto, explica que o versículo se aplica a ambos os casos, seja a mulher noiva ou já casada. Ele deriva a lei deste modo por conta do conectivo "e" no começo do versículo, uma palavra aparentemente desnecessária mas que viria, segundo ele, para indicar que sempre que isso ocorrer deve-se aplicar a morte por fogo. A discussão dos dois sábios sobre o tema é apresentada do seguinte modo no Talmud:

O Rabi Akiva lhe disse: Ishmael, meu irmão, eu interpreto o versículo como falando de filhas e filhas [tanto as casadas, como as noivas; o "e" no começo do versículo o leva a pensar assim]. O Rabi Ishmael lhe respondeu: E porque você entende o versículo como "filhas e filhas" uma mulher será queimada no fogo.

(San'hedrin 51b) 


\section{OS SÁBIOS DO TALMUD E AS LEIS ESTABELECIDAS NA MISHNÁ}

Ao longo do trabalho viram-se as bases do sistema legislativo rabínico, de onde derivava a autoridade que eles tinham para definir a lei e também alguns métodos e princípios que pautavam esse ofício.

Nesta parte do trabalho analisaremos especificamente a atividade legislativa dos sábios amoraítas, uma das mais importantes e que mais influenciou o judaísmo daquele então em diante.

É sabido que uma das principais ocupações dos sábios do Talmud era explicar a Mishná com o intuito de definir a lei e tomar decisões haláchicas. Assim, boa parte do texto do Talmud e da produção literária amoraíta consiste em leituras e comentários da Mishná, no sentido mais amplo do termo.

Com relação à Mishná, os amoraítas a explicavam; procuravam por razões para as leis trazidas; se viam que a lei era bíblica, procuravam evidências do fato no texto da Bíblia; buscavam os limites e consequências das leis; analisavam como as leis deveriam ser cumpridas; tentavam conciliar visões divergentes entre os sábios; restringiam ou expandiam um conceito; refinavam e retificavam a linguagem utilizada no texto; comparavam fontes diversas que tratavam do mesmo assunto; identificavam os autores de certos ditos etc. São esses tipos de atividades que analisaremos aqui.

7.1. Um amoraíta jamais discorda de um tanaíta

Em primeiro lugar, é importante dizer que apesar dos vários métodos usados pelos sábios amoraítas para analisar e comentar os textos dos tanaítas (a Mishná), a sua atuação tinha uma limitação que pode ser considerada de ordem hierárquica. Um princípio geral que consta do Talmud afirma que "um amoraíta jamais discorda de um tanaíta" (Bechorot 28a; Eruvin 80a etc). Na época dos amoraítas não era visto com bons olhos discordar do que foi dito pelos tanaítas, ou até mesmo de atos atribuídos a eles. Assim, quando uma fonte tanaíta parece 
contradizer as palavras de um sábio amoraíta, o sábio em questão precisa voltar às fontes tanaítas e anular a contradição existente. Essa anulação pode ser feita de várias maneiras, mas as principais delas são: ou pela explicação da fonte tanaíta como se aplicando a um caso diferente do caso trazido e abordado pelo sábio amoraíta; ou pela limitação da aplicação da fonte tanaíta.

No caso de o amoraíta não conseguir anular a contradição - chamada tecnicamente de tiuvatá ("resposta", em aramaico) - da fonte tanaíta, a conclusão formulada no Talmud é: tiuvatá de Rabi P'loni tiuvatá, ou seja, "a resposta do Rabi Fulano é uma resposta", o que quer dizer que o fato de ele não conseguir resolver a contradição é uma resposta suficiente de que suas palavras devem ser rejeitadas em prol das palavras dos tanaítas.

Mishná: O que lê (a oração de Shemá) deste momento em diante não causou perda, como a pessoa que lê a Torá (Berachot 1:2).

Talmud: O Rav Chisdá disse em nome do Mar Ucva: com a condição de que a pessoa não diga "cria a luz". Uma refutação: o que lê deste momento em diante não causou perda, como a pessoa que lê a Torá, e deve abençoar com duas bênçãos antes e uma depois. A resposta do Rabi Chisdá é uma resposta (Berachot 10b).

O momento para fazer a oração de Shemá pela manhã é até o final da terceira hora legal ${ }^{79}$ do dia. A Mishná diz que quem for ler a Shemá depois desse horário não causa perda alguma, ou seja, não deixa de cumprir nenhum mandamento e, mesmo que o horário correto tenha passado, ele pode ler o texto, pois a ele se aplicam as mesmas leis de uma pessoa que lê qualquer outro texto da Torá.

O Rav Chisdá, então, um sábio amoraíta, traz uma ideia pessoal e diz que a bênção “cria a luz" - a primeira bênção que se deve fazer antes de ler a Shemá - não deve ser feita pela pessoa depois do horário estabelecido para leitura de Shemá. No entanto, logo a seguir as suas palavras são contraditas, pois uma fonte não especificada traz uma beraita - uma fonte tanaíta que não entrou na Mishná - na qual está escrito explicitamente que a pessoa pode fazer as duas bênçãos que precedem a Shemá normalmente, mesmo depois do horário legal. Como o Rabi

\footnotetext{
${ }^{79}$ A hora legal é a medição de hora usada na Mishná e no Talmud e cuja duração pode variar dependendo da época do ano. O cálculo é feito calculando-se quantos minutos há entre o nascer do sol e o pôr do sol e dividindo-se o valor em doze partes iguais. O mesmo é feito para a noite, do pôr do sol até o nascer do sol do dia seguinte, e a divisão em doze partes. Cada uma destas partes é a chamada "hora legal".
} 
Chisdá não consegue anular a refutação levantada contra ele, o texto do Talmud conclui: A resposta do Rabi Chisdá é uma resposta. Isso significa que a sua opinião é registrada como tal mas não deve ser aceita.

\subsection{Determinação da halachá}

Já foi visto que como líderes e instrutores dos povos, e, em alguns casos até mesmo como juízes em tribunais, os amoraítas se viam na obrigação de definir a lei religiosa, a halachá, em casos de disputas entre os tanaítas ou até mesmo em caso de divergências entre amoraítas. Este ramo de atividade amoraíta, um dos mais importantes e recorrentes, também era limitado e pautado por algumas regras e princípios.

\subsubsection{Princípios na definição da lei}

Um dos princípios mais comuns estabelecidos pelos amoraítas é aquele que diz que no caso de divergência entre dois sábios tanaítas, a lei segue sempre um deles. Por exemplo, já na época dos tanaítas ficou decidido que em disputas entre a Escola de Shamai e a Escola de Hilel a lei é sempre conforme a Escola de Hilel (Cf. Eruvin 6b e 13b). Na mesma época ficou decidido ainda que em caso de disputas entre o Rabi Eliezer e o Rabi Iehoshua (Cf. Shabat 130b), a lei é sempre conforme este, e não aquele.

O Rabi Iochanan, um amoraíta da segunda geração, estabeleceu que "em todo lugar onde o Raban Shimon ben Gamliel ensina algo em nossa mishná, a halachá é conforme ele, a não ser nos casos de: fiador, do ocorrido em Tsidon, e daquele que achou uma evidência tardia" (Bava Qama 69a). ${ }^{80}$

De modo similar, Shemuel, da primeira geração de amoraítas da Babilônia, decretou que " $a$ halachá é conforme o Rabi Meir quando se trata de seus decretos"81 (Eruvin 47a). E,

\footnotetext{
${ }^{80}$ Os três casos de disputa mencionados são: fiador - Bava Metsia 10:7, o caso de Tsidon - Guitin 7:5 e o da evidência tardia - San'hedrin 3:8.

${ }^{81}$ Guezerot, proibições rabínicas em assuntos permitidos pela lei da Torá. Em geral, esse tipo de sanção é feito para criar "cercas protetoras" que evitam a transgressão da lei.
} 
desse mesmo modo, há muitos outros, como: "Shemuel e Rabi Iochanan, a halachá é conforme o Rabi Iochanan" (Eruvin 47b), ou "a halachá é conforme o Rav nas leis que não dizem respeito a assuntos monetários, e conforme Shemuel em assuntos monetários" (Bechorot 49b).

\subsubsection{A definição da lei em casos singulares e sua linguagem}

Apesar de serem guiados por princípios gerais como o anterior, em vários momentos os sábios precisavam definir a lei em casos particulares, nos quais os príncipios gerais não davam a diretriz necessária. Na grande maioria desses casos, a fórmula usada pelo Talmud é: Amar Rabi P'loni Hahalachá ke Rabi P'loni (O Rabi Fulano disse que a halachá é conforme o Rabi Sicrano). Além dessas, há, obviamente, outras expressões frequentemente utilizadas.

A Mishná diz que na Shacharit, no Mussaf, na Minchá e na Neilá82 ocorre a bênção dos sacerdotes, são as palavras do Rabi Meir. O Rabi Iehudá diz que a bênção é feita na Shacharit e no Mussaf, mas não na Minchá e na Neilá. O Rabi Iossi diz: Na Neilá se faz a bênção, mas na Minchá não... O Rabi Iehudá, em nome do Rav, disse: A halachá é conforme o Rabi Meir. O Rabi Iochanan disse: O povo segue o costume do Rabi Meir. O Rava disse: $O$ costume é conforme o Rabi Meir. Aquele que disse "a halachá é conforme o Rabi Meir" afirma que ele ensinava isso em público. Aquele que disse "o costume é conforme o Rabi Meir" afirma que ele não ensinava isso em público, mas se alguém lhe perguntava sobre o assunto, ele dizia isso. Aquele que disse "o povo segue o costume do Rabi Meir" afirma que mesmo que alguém pergunte a respeito não se ensina isso e se a pessoa já tem esse costume e age conforme ele, não fazemos com que ela o abandone. O Rav Nachman disse: A halachá é conforme o Rabi Iossi e a halachá é de fato conforme o Rabi Iossi (Taanit 26b).

Aqui temos uma discussão entre tanaítas a respeito da bênção sacerdotal e sobre quando ela é feita. Os tanaítas que debatem o assunto são o Rabi Meir, o Rabi Iehudá e o Rabi Iossi. Três sábios amoraítas, baseando-se na disputa, dizem que a lei é conforme o Rabi Meir, mas cada um diz isso de um jeito diferente. O Rav diz simplesmente que a lei é conforme o Rabi Meir. O Rabi Iochanan diz que o povo segue o costume do Rabi Meir. E o Rava diz que o costume é conforme o Rabi Meir.

\footnotetext{
${ }^{82}$ Shacharit é a oração diária matinal; mussaf, a oração especial do sábado (Shabat) ou dos dias festivos; minchá, a oração diária vespertina e neilá a oração de encerramento do dia do Iom Kipúr.
} 
Em seguida, o próprio texto do Talmud explica qual é a diferença entre essas três formas de expressão dos amoraítas. Quando o Rav diz que a lei é como o Rabi Meir, está falando da halachá propriamente dita, e, portanto, ela deveria ser ensinada e divulgada, podendo ser passada por um rabino em seu sermão diante da comunidade. O costume significa que a lei é menos clara e definida, e, portanto, ela não deve ser mencionada em sermões públicos, só em casos que alguém vai ao rabino e lhe pergunta especificamente como agir. Nesse caso deve-se ensinar o costume para a pessoa. Por fim, o costume que o povo segue é um status ainda inferior ao do costume. Não só ele não deve ser mencionado em sermões públicos, bem como mesmo que uma pessoa venha perguntar sobre a lei, não se deve passar esse ensinamento como fonte de informação. A única validade do costume do povo é que se uma pessoa já segue isso, não se deve dizer para que ela mude o seu hábito, afirmando que o que ela faz é errado. No final do trecho, o Talmud traz a opinião do sábio amoraíta Rav Nachman, que discorda dos três outros amoraítas (o Rav, Rava e o Rabi Iochanan) e que afirma que a lei não segue o Rabi Meir, mas sim o Rabi Iossi.

Caso similar podemos ver no assunto da Havdalá ${ }^{83}$ feita no meio da reza de Amidá. ${ }^{84}$ O ensinamento da Mishná é: " $a$ Havdalá é feita em Chonen Hadáat ${ }^{85}$. O Rabi Akiva disse: A quarta bênção deve ser lida por si só. O Rabi Eliezer diz: ela é feita em Hodaá ${ }^{86}$ (Berachot 5:2).

Os sábios tanaítas discutem sobre em que parte da oração de Amidá deve-se fazer a reza de Havdalá. A opinião geral é de que ela é feita na oração de Chonen Hadáat, a quarta da ordem, e o Rabi Eliezer diz que ela deve ser feita na oração de Horaá, a décima sétima da sequência estabelecida.

No Talmud vemos o seguinte:

Ele disse: Vocês falaram em nome do Rabi Iochanan dizendo que a halachá é segundo o Rabi Eliezer nos dias festivos que caem depois do Shabat? Responderam para ele: Sim... Ele disse: Mas não se trata de halachá, e sim de uma opinião à qual nos inclinamos, pois foi dito: O Rav Itschac bar Avdimi disse em nome do nosso mestre: Esta é a halachá, mas há os que dizem que é apenas uma opinião à qual nos inclinamos. O Rabi Iochanan disse: É algo com que se concorda. O Rabi Chia bar Aba disse: Isso parece ser o certo (Berachot 33b).

Nesse caso também vemos quatro maneiras diferentes de definir a lei segundo o Rabi Eliezer no que diz respeito a um dia festivo que cai depois de um dia de Shabat. Um sábio

\footnotetext{
${ }^{83}$ A cerimônia feita ao término do dia de Shabat.

${ }^{84}$ Oração composta por dezoito bênçãos e recitada três vezes ao dia, diariamente.

85 "Dotador da sabedoria". Uma das dezoito bênçãos da Amidá,

86 "Benção de louvor". Outra das dezoito bênçãos da Amidá.
} 
define isso como uma halachá, outro como uma "opinião à qual nos inclinamos", outro como uma coisa com que se concorda e, por fim, o outro a define como algo que "parece ser o certo".

Frente a essas diferentes fórmulas de linguagem existem vários debates dos comentaristas a respeito dos diferentes status de cada uma dessas expressões e se, de fato, todas elas são usadas para definir que a lei é desse modo. O Rashi, um dos comentaristas mais respeitados, diz (Berachot 33b, d.h. halachá e d.h. modim) que a diferença discutida neste trecho é similar ao trecho anterior, ou seja, ela diz respeito a se estas informações podem ser passadas em sermões públicos e como se fossem a lei, ou se são coisas que só devem ser ensinadas quando alguém pergunta particularmente sobre isso ou já segue esse costume.

\subsubsection{A definição da lei por meio da negação}

Há casos em que os amoraítas definem a lei, não afirmando qual é ela, mas sim por meio de uma negação. Nesses casos, são comuns expressões como ein hahalachá kerabi P'loni (a lei não é conforme o Rabi Fulano) e leit halachta kevateia (a lei não é conforme ele).

\subsection{Explicação da Mishná}

Muitas vezes, antes de definir a lei ou aplicar princípios legislativos gerais, os sábios do Talmud tinham de se engajar na explicação da Mishná. Essa atividade, em geral chamada de Perush (פרוש), podia ser expressa em diversas áreas: a interpretação e explicação de palavras crípticas do texto, a interpretação dos assuntos sendo discutidos, a determinação de medidas que não ficaram claras, entre outros.

\subsubsection{Explicação de palavras}

A Mishná frequentemente traz termos hebraicos pouco usados ou raros, o que exigia que os amoraítas os interpretassem e explicassem para assim definir a lei. Às vezes, o texto traz 
expressões que para serem compreendidas corretamente devem ser definidas com precisão. Muitas vezes a interpretação dada para uma palavra, e em especial as aplicações de um certo termo, são alvo de disputas e divergências entre os sábios e podem chegar a ocupar páginas e páginas do Talmud. Eis alguns exemplos:

Mishná: Se [as folhas] fenderam (do lulav) ${ }^{87}$, é inválido; se separaram, é válido (Sucá $3: 1)$.

Talmud: O Rav Papa disse: "Se fenderam" significa que as folhas estão juntas na base, como as cerdas de uma vassoura. "Se separaram" significa que as folhas estão juntas na base, mas que se separaram na ponta, como em um leque. (Sucá 32a).

Os sábios do Talmud estão tentando entender a diferença entre um lulav fendido, e outro separado, pois isso influencia a lei. Segundo a Mishná, o primeiro tipo não pode ser usado no ritual, e o segundo pode. Então a preocupação é entender exatamente e com precisão o que cada termo significa.

Mishná: Quando bois ou novilhos são queimados adequadamente, eles são queimados no Beit habirá, e eles não impurificam a roupa dos que se envolveram na sua queima (Zevachim $12: 5)$

Talmud: $O$ que significa Beit habirá? O Raba bar bar Chana disse em nome do Rabi Iochanan: É um local no Monte do Templo, e ele se chama Birá. Reish Lakish disse: Todo o Monte do Templo é chamado de Birá, pois está escrito: e para edificar o palácio (Birá) para o qual tenho providenciado (1 Crônicas 29:19) (Zevachim 104b).

Nesse caso vemos que existe uma divergência entre dois sábios com relação ao significado da palavra Birá. O Raba bar bar Chana dá a sua explicação baseado em algo que ouviu de seu mestre, o Rabi Iochanan. Já o Reish Lakish dá a sua interpretação baseando-se em um versículo das Escrituras.

Outra maneira que o Talmud muitas vezes usa para tentar entender e explicar o significado de uma palavra é recorrer à sua tradução ao aramaico:

\footnotetext{
${ }^{87}$ Lulav é a folhagem da tamareira e uma das quatro espécies usadas na festa judaica de Sucot (Festa das Cabanas).
} 
Mishná: abóbora remutsá (termo hebraico, Nedarim 6:1).

Talmud: O que é uma abóbora remutsá? Shemuel disse: É a abóbora de Carcuzai. O Rav Ashi disse: É uma abóbora envolta em brasas (rêmets, termo aramaico) (Nedarim 51a).

\subsubsection{Explicação do assunto}

Quando os amoraítas precisam interpretar um trecho da Mishná, o comentário se baseia, em geral, no assunto que está sendo debatido. Em muitos casos as palavras usadas são simples e claras, mas, mesmo assim, os sábios vêem a necessidade de explicar alguma coisa específica que está faltando no assunto em debate. Vejamos dois exemplos:

Mishná: Todos os mandamentos do filho que recaem sobre o pai - os homens estão obrigados, e as mulheres estão isentas. E todos os mandamentos do pai que recaem sobre o filho - tanto os homens como as mulheres estão obrigados (Kidushin 1:7).

Talmud: O que significa "todos os mandamentos do filho que recaem sobre o pai?" Se dissermos que se trata de qualquer mandamento que o filho deve fazer para o pai, eis que a mulher não está isenta! Já foi ensinado que quando se usa o termo "pessoa", isso alude tanto ao homem como à mulher. O Rab Iehudá respondeu: O que o trecho quis dizer é: "todos os mandamentos que o pai deve fazer por meio do filho"; e nesses casos os homens estão obrigados e as mulheres estão isentas (Kidushin 29a).

\section{Outro caso:}

Mishná: Se dentro dele caiu um touro, surdo, anormal, ou um pequeno, está obrigado (Bava Qama 5:6).

Talmud: O que significa "touro, surdo, anormal, ou um pequeno"? Se dissermos que isso quer dizer "touro de um homem surdo", "touro de um homem anormal" ou "touro de um menor" [...] O Rabi Iochanan disse: Trata-se de um touro que era surdo, um touro que era 
anormal, ou um touro que era pequeno (Bava Qama 54a).

\subsubsection{Determinação de medidas}

Em vários casos as explicações dos amoraítas vêm para definir uma quantidade, uma medida, a idade correta ou o período de tempo que está sendo discutido pela Mishná. Em grande parte desses casos, a explicação se faz necessária pois a Mishná em si não explicita a medida; ou, a explicita, mas não de modo suficientemente claro, sendo preciso defini-la com mais exatidão.

Mishná: Aquele que morreu e deixou filhos e filhas. Se suas posses são muitas, os filhos as herdam, e as filhas não. Se suas posses são poucas, as filhas não herdam e os filhos devem pedir pelas portas (Bava Batra 9:1).

Talmud: O que significa "são muitas"? O Rav Iehudá disse em nome do Rav: O suficiente para que uns e outros [filhos e filhas] possam se manter por doze meses. Quando eu disse isso diante de Shemuel, ele disse: Esta é a opinião do Raban Gamliel, filho do Rabi, mas os outros sábios dizem que as posses devem ser suficientes para manter a uns e outros até que eles atinjam a maioridade (Bava Batra 139b).

Mais um exemplo:

Mishná: Pode-se comer e beber casualmente fora da Sucá (Sucá 2:4).

Talmud: E quanto de comida ainda é considerado uma refeição casual? O Rav Iossef disse: dois ou três ovos. O Abaiê perguntou a ele: Mas não há casos em que essa quantidade já é o suficiente para servir como uma refeição para a pessoa? Então o Abaiê disse: casual é a comida que um aluno come quando está com pressa para chegar à Casa de Estudos (Sucá 26a).

7.3.4. Explicação da razão de ser de uma lei 
A Mishná sozinha dá, às vezes e em raros casos, as causas e os motivos para suas leis, por exemplo: Não se pode colher a Peá88 com foices ou extraí-la com pás para que uma pessoa não machuque o seu companheiro (Peá 4:4). E, às vezes, também encontramos a menção do fato causador de uma lei, como: No começo costumava-se receber os testemunhos do início do novo mês de qualquer pessoa. Desde que os hereges perverteram [a lei], estabeleceu-se que só seriam recebidos os testemunhos dos mensageiros (Rosh Hashaná 2:1). ${ }^{89}$

No entanto, essas são exceções e, geralmente, a Mishná é hermética e não explicita os motivos ou causas para que uma certa lei fosse estabelecida. Essa função ficou, como já foi visto, nas mãos dos amoraítas.

Na maioria dos casos o Talmud mistura a razão para uma lei com a citação direta da Mishná sem qualquer marcação gramatical ou lexical especial. No entanto, em alguns casos a razão para um mandamento é dada como a resposta da pergunta mai tama? (מאי טעמא, qual é o motivo?), ou outras do tipo. Existem, obviamente, diversos casos em que as razões apresentadas são conflitantes, sendo que um sábio amoraíta justifica a lei de um modo, e outro sábio, de outro (Cf. MELAMED, 1973, p. 340).

Um exemplo do motivo sendo trazido como resposta à pergunta mai tama? pode ser visto em:

Mishná: A pessoa não pode quebrar um caco de barro ou rasgar um papel [em um feriado religioso] para assar neles peixe salgado (Betsá 4:5).

Talmud: Mai tama? (Por que motivo?) Porque isso se constitui em reparo de um utensílio [e esse tipo de ato é proibido nos feriados religiosos] (Betsá 32b).

7.3.5. Busca de uma fonte para a lei

\footnotetext{
${ }^{88}$ A quina de um campo que, segundo a Bíblia (Levítico 19:9 e 23:22), deve ser deixada para o pobre.

${ }^{89}$ Antigamente, o início do mês judaico era definido quando duas testemunhas compareciam diante do Tribunal Rabínico e atestavam terem visto a Lua Nova. O texto informa que esse costume foi mudado, e que se passou a aceitar apenas o testemunho de mensageiros nomeados pelo Tribunal Rabínico, e não de qualquer testemunha.
} 
Assim como os amoraítas se preocupavam em entender os motivos para uma lei, diversas vezes, concomitantemente, preocupavam-se em buscar uma fonte para determinada lei, ou seja, o versículo na Torá que inspirara aquela decisão legal. Na maioria dos casos, essas fontes são introduzidas com o uso da expressão mena hinê milêe? (de onde são estas palavras?) ou simplesmente menalan? (de onde veio?).

Mishná: Se um feriado religioso cai na véspera do dia de Shabat [ou seja, sexta-feira], a pessoa não pode cozinhar no feriado uma comida que se destina ao dia de Shabat, mas ela pode preparar um cozido na véspera do feriado e usar as sobras para o Shabat (Betsá 2:1).

Talmud: mena hinê milê? (de onde são essas palavras?) Shemuel disse: Do versículo que diz: "lembra-te do dia de Shabat para santificá-lo" (Êxodo 20:7). O termo "lembra-te" é uma alusão para se lembrar daquilo que podemos vir a esquecer. E por que motivo instituíram essa lei? O Rava respondeu: Para se certificar de que uma bela porção de comida seja preparada para o dia de Shabat, e outra bela porção para o feriado religioso. O Rav Ashi respondeu: Para que a pessoa lembre que se ela não pode cozinhar em um feriado religioso para o dia de Shabat, muito menos cozinhar em um feriado religioso para um dia normal (Betsá 15b).

A Mishná diz que se um feriado cai na véspera de Shabat, é proibido cozinhar alguma coisa no próprio feriado para o dia de Shabat. O que se deve fazer é preparar um cozido ainda antes do feriado e guardá-lo para o dia de Shabat. Uma vez feito isso, o que se cozinha durante o feriado pode ser usado no dia de Shabat, se houver restos. Isso é o que se chama, na halachá, Eruv Tavshilin (mistura dos cozidos). A pergunta do Talmud é: qual é a fonte que gerou esse costume? A resposta é encontrada pelos sábios amoraítas em um versículo da Torá: lembra-te do dia de Shabat para santificá-lo" (Êxodo 20:7), no qual eles entenderam que a expressão "lembra-te" pede para se lembrar daquilo que podemos vir a esquecer, isto é, como o feriado coincide com o dia de Shabat, existe o temor de que a pessoa faça todos os preparativos para o feriado mas se esqueça do dia de Shabat.

No entanto, essa resposta não satisfaz totalmente o Talmud, pois o mero uso da expressão "lembra-te" não parece indicar uma obrigação específica de preparar os cozidos e misturá-los. Portanto, outra pergunta é feita, ligeiramente diferente: E por que motivo instituíram essa lei?, isto é, a respeito desse regulamento concernente ao preparo da comida. $\mathrm{Na}$ resposta ao caso vemos uma divergência entre dois amoraítas. O Rava segue a mesma linha 
de raciocínio iniciada antes, e explica que a pessoa precisa preparar um cozido para o dia de Shabat ainda antes do cozido para o feriado para que o dia de Shabat não fique sem uma comida especial, uma boa porção, preparada para si. Já o Rav Ashi dá outra interpretação: alguém poderia pensar que seria possível cozinhar para o dia de Shabat durante o feriado, dada a importância do sábado. Mas com isso, diz o Rav Ashi, a pessoa estaria desprezando e negligenciando o feriado em si, porque estaria preocupada com a comida em honra do dia de Shabat. Assim, esta lei teria sido estabelecida para as pessoas se lembrarem e darem a devida importância ao feriado (e não ao dia de Shabat, conforme entende o Rava).

Existem casos em que o versículo usado como prova de uma lei e o motivo para ela se encontram juntos na explicação:

Mishná:Uma sucá90 com mais de vinte cúbitos de altura é inválida (Sucá 1:1).

Talmud: De onde se aprende isso? O Raba disse: Do versículo "Para que as vossas gerações saibam que nas cabanas fiz habitar os israelitas" (Levítico 23:43). Até vinte cúbitos o homem sabe que habita em uma cabana (Sucá 2a).

Segundo o Raba, o versículo ordena que o homem saiba - sinta - que ele está morando em uma cabana e não em uma casa fixa, ou outro tipo de construção. Se o teto da sucá está a mais de 20 cúbitos do solo, a pessoa que está na cabana não "sente" o teto e portanto não "sabe" que está em uma cabana, segundo sua opinião.

\subsubsection{Busca de uma causa para a lei}

Diversas leis religiosas foram estabelecidas depois de um ocorrido ou de um fato particular. Às vezes o fato que levou a estabelecer a lei daquele modo é apenas aludido na Mishná, e os amoraítas se debruçam sobre ele e o expõem de maneira completa.

Mishná: Se uma mulher e seu marido foram para o exterior [...] e quando ela volta ela diz: "meu marido morreu"- ela pode se casar de novo. Se ela disser "meu marido morreu”, ela pode se casar por levirato [...] A Escola de Hilel diz: Nós ouvimos essa tradição apenas no

\footnotetext{
${ }^{90}$ Cabana construída para celebração do feriado de Sucot.
} 
caso da mulher que veio da colheita, e no mesmo país, como ocorreu certa vez (Ievamot 15:12).

Talmud: O que foi que ocorreu? O Rav Iehudá disse em nome de Shemuel: No período final da colheita, dez homens foram colher o trigo. Um deles foi picado por uma cobra $e$ morreu. A sua esposa veio e testemunou diante do tribunal. Eles mandaram emissários e verificaram a história, que era verdadeira. Naquele momento eles decretaram que quando um mulher diz: "meu marido morreu"- ela pode se casar de novo. Se ela disser "meu marido morreu”, ela pode casar por levirato (Ievamot 116b).

Existem também casos em que a Mishná não alude a nenhum caso ou evento que tenha motivado a definição da lei, e são os amoraítas que o mencionam pela primeira vez:

Mishná: Um homem não pode sair [no dia de Shabat] com uma sandália presa com pregos (Shabat 6:2).

Talmud: "Sandália presa com pregos". Qual é o motivo? Shemuel disse: Isso foi no final do período de perseguição [época da revolta de Bar Cochva, quando havia perseguição ao povo judeu], e havia alguns fugitivos se escondendo em uma caverna. Eles disseram: quem quiser entrar, que entre; mas quem quiser sair, não sairá. Eis que a sandália de um deles ficou virada, e por isso eles pensaram que um deles tinha saído da caverna e tinha sido visto pelos inimigos que, agora, viriam atrás deles. Eles começaram a se pressionar, e começaram a se matar uns aos outros, mais do que os inimigos tinham matado a eles. Rami bar Iechezkel disse: Eles estavam parados em uma sinagoga e ouviram um som vindo dos fundos da sinagoga. Achando que o inimigo estava vindo sobre eles, ele se pressionaram e se mataram, mais do que os inimigos tinham matado a eles. Naquele momento foi decretado: Um homem não pode sair com uma sandália presa com pregos (Shabat 60a).

7.4. Restrição ou ampliação da lei estabelecida na Mishná

Em diversos casos a restrição de uma lei ocorre na própria Mishná, fruto do trabalho dos sábios tanaítas. Anteriormente, por exemplo, vimos que a Escola de Hilel estabelece que a 
lei da mulher que afirma que seu marido morreu só se aplica em um caso específico, se o marido estava na colheita, e no mesmo país que a esposa. Isso nada mais é do que uma restrição na aplicação da lei trazida na própria Mishná.

Em geral essas restrições são introduzidas por expressões como bemá dvarim amurim? (de que casos está se tratando?) ou eimatai? (quando isso se aplica?). Por exemplo:

Mishná: Se uma oliveira contendo dois seá91 foi deixada para trás, ela não é considerada abandonada. Bemá dvarim amurim? (De que casos está se tratando?) Só quando o dono não começou a colher dela (Peá 7:2).

Mishná: leão, urso, leopardo, pantera e cobra são acidentes inevitáveis. Eimatai? (Quando isso se aplica?). Se os animais vieram por conta própria (Bava Metsia 7:9).

Quando se trata de uma expansão da lei, a Mishná costuma usar os termos veken (e assim é) e veaf (e também):

Mishná: Tanto o touro como qualquer outro animal doméstico são iguais [perante a lei] no que diz respeito à queda em um buraco [...] veken (e assim é) para os animais selvagens e aves (Bava Qama 5:7).

Mishná: Há uma obrigação da Torá de descarregar, mas não de carregar. O Rabi Shimon diz: veaf (também) de carregar (Bava Metsia 2:10).

Este mesmo tipo de atividade foi feita pelos amoraítas, restringindo ou ampliando os casos em que a lei da Mishná se aplica.

7.4.1. Restrição da lei estabelecida na Mishná

As restrições a uma lei imposta pelos amoraítas, na maioria dos casos, deve-se ao fato de que os sábios do Talmud viram a lei válida apenas sob certas circunstâncias e em condições

\footnotetext{
${ }^{91}$ Medida volumétrica. Cada seá equivale a 8,29 litros, segundo opinião mais aceita.
} 
específicas. No entanto, algumas vezes uma lei é restringida por causa de um outro dito de um Sábio, ou porque um texto que não estava sendo debatido é trazido à pauta da discussão. Nesse último caso às vezes ainda se acrescentam certas condições e circunstâncias para que a lei seja aplicada.

Do mesmo jeito que os sábios da Mishná tinham expressões preferenciais para tratar da restrição de uma lei - como bemá dvarim amurim? (de que casos está se tratando?) ou eimatai? (quando isso se aplica?) - os sábios do Talmud costumavam usar expressões fixas para introduzir limitações da lei trazida na Mishná. A mais comum dessas expressões é lo shanu ela (não ensinaram isso, a não ser quando...). Outra expressão que aparece com relativa frequência é vehú she... (só quando...).

Mishná: Se uma pessoa fez sua sucá sob uma árvore, é como se ela tivesse sido feita dentro de sua casa (Sucá 1:2).

Talmud: O Rava disse: Lo shanu ela (Não ensinaram isso, a não ser quando) se trata de uma árvore que projeta mais sombra do que luz, mas se for uma árvore que projeta mais luz do que sombra, a sucá é válida (Sucá 9b).

Mishná: O que diz para uma mulher: "Eis que você está consagrada a mim com a condição de eu falar junto ao governo sobre ti" [...] se de fato ele falou dela junto ao governo, ela está consagrada (Kidushin 3:6).

Talmud: O Reish Lakish disse: Vehu she (Só quando) ele também deu um dote (Kidushin 63a).

Aqui cabe perguntar quais são os motivos para esse fenômeno de limitar à lei da Mishná? Será que essas restrições e limitações eram estabelecidas com base em uma tradição estabelecida, ou será que se trata de um caso de inovação e renovação das leis, um caso de legislação puramente amoraíta? A respeito disso, De Vries diz:

\footnotetext{
Supostamente, essa forma literária é reflexo de uma tradição e em alguns casos podese tentar rastrear essa tradição. Mas há casos, e que se podem provar com quase total certeza, de que não se trata de uma tradição, mas de uma nova visão do seu enunciador, fruto do seu pensamento aplicado a uma necessidade específica ou a mudanças de condições e que, às vezes, chegam a ser contrárias à tradição estabelecida.
}

(De Vries, Toldot Hahalachá Hatalmudit, p. 129).

Assim, segundo De Vries, mais do que uma simples atividade interpretativa da Mishná, existe aqui um processo legislativo original, a criação de novas leis, ou seja, uma produção autêntica dos amoraítas. 
7.4.2. Ampliação da lei estabelecida na Mishná

Em alguns casos específicos, os amoraítas ampliaram as leis da Mishná, mas, esses são bem mais raros se comparados aos casos de restrição da lei. Em geral, a expressão utlizada pelos amoraítas nesses casos é afilu (até mesmo quando).

Mishná: Se uma pessoa roubou um animal e ele envelheceu, ou escravos, e eles envelheceram, ela paga segundo o valor no momento do roubo (Bava Qama, 9:2).

Talmud: O Rav Papa disse: "Envelheceu" não significa envelhecer de fato, mas afilu (até mesmo quando) se trata de algo que deteriorou (Bava Qama, 96b).

7.5. Precisão com relação à linguagem da Mishná

Do mesmo jeito que muitas vezes os sábios sentiram a necessidade de interpretar palavras da Torá Escrita, bem como expressões e até mesmo letras, o mesmo ocorreu com os amoraítas em relação à linguagem usada pelos tanaítas na Mishná. Há casos em que a análise se debruça sobre a linguagem simples e literal do texto mishnaico; e há casos em que a análise se debruça sobre aparentes redundâncias e contradições no texto.

7.5.1. Precisão com relação à linguagem literal da Mishná

Precisão da linguagem literal significa que os sábios têm a intenção de explicar detalhes aos quais a Mishná apenas aludiu com o uso de uma palavra ou expressão específica, ou porque usou um termo e não outro similar. Por exemplo:

Mishná: Um homem pode consagrar sua filha quando ela é jovem. 
Talmud: Quando ela é jovem, sim. Quando ela é menor de idade, não. Isso corrobora o Rav, que disse: é proibido que o homem consagre a sua filha quando ela é menor de idade, até que ela cresça o suficiente para poder dizer "com este eu quero me casar” (Kidushin, 41a).

O Talmud se debruça sobre a linguagem da Mishná e aprende do uso da palavra “jovem” que a Mishná se refere apenas à mulher com mais de 12 anos e um dia de vida, e não à menor de idade (abaixo de 12 anos).

\subsubsection{Precisão com relação a redundâncias na Mishná}

Detalhes especiais mencionados na Mishná que parecem ser redundantes precisam de uma tsrichuta [lit., "necessidade"], isto é, uma explicação dos amoraítas do por que a Mishná precisou mencionar todos eles.

Há casos em que os amoraítas concluem que um dos detalhes mencionados é, de fato, redundante, mas que, mesmo assim, ele foi trazido por fazer parte do jeito com que aquele trecho foi ensinado ao longo do tempo:

Mishná: Toda vez que é permitido comer [chamêts na véspera de Pêssach], também é possível usar isso para alimentar os animais domésticos, os animais selvagens e as aves (Pessachim 2:1).

Talmud: Por que a Mishná menciona animais domésticos e animais selvagens? Ambos são necessários, pois se ela falasse apenas dos animais domésticos, alguém poderia pensar que eles podem ser alimentados, pois é possível ver o que eles deixaram de sobra da comida [e é possível eliminar os restos], mas os animais selvagens, que escondem o resto das comidas, não podem ser alimentados. E se ela falasse apenas dos animais selvagens, alguém poderia pensar que eles podem ser alimentados pois eles escondem os restos de comida e não se transgride a lei, mas que não se pode alimentar animais domésticos pois eles deixam os restos expostos $e$ pode-se esquecer de eliminá-los. Por isso os dois tipos foram mencionados. E por que o texto precisa mencionar as aves? Uma vez que ela ensinou sobre os animais domésticos e os animais selvagens, ela também ensinou sobre as aves (Pessachim 21a). 
Embora na maior parte dos casos a redundância de um conceito se encontra dentro de um mesmo trecho da Mishná, há casos em que uma mishná inteira é repetida em dois trechos diferentes. Por exemplo:

Se um homem consagra uma mulher com a condição de que ela não tenha votos sobre si, e posteriormente se descobre que ela têm votos, ela não está consagrada. Se ele se casa com ela incondicionalmente, e depois se descobre que ela tinha votos sobre si, ela pode ser divorciada sem o documento atestando isso (Kidushin, 2:5).
Se um homem consagra uma mulher com a condição de que ela não tenha votos sobre si, e posteriormente se descobre que ela têm votos, ela não está consagrada. Se ele se casa com ela incondicionalmente, e depois se descobre que ela tinha votos sobre si, ela pode ser divorciada sem o documento atestando isso (Ketuvot, 1:7).

Os amoraítas não deixaram isso passar despercebido e abordam o assunto redundante em ambos os lugares:

Aqui isso é necessário para o assunto de casamentos (kidushin), e as leis de noivado (ketuvot) foram ensinadas por meio das leis do casamento. Lá era necessário para o assunto dos noivados, e as leis de casamento foram ensinadas por meio das leis do noivado (Kidushin 50a).
Aqui isso é necessário para o assunto de noivados (ketuvot), e as leis de casamento (kidushin) foram ensinadas por meio das leis do noivado. Lá era necessário para o assunto dos casamentos, e as leis de noivado foram ensinadas por meio das leis do casamento (Ketuvot 72b). 


\subsubsection{Precisão com relação a contradições na Mishná}

A necessidade de precisão dos sábios amoraítas também fez, obviamente, que eles comparassem duas mishnaiot entre si para contrastar a lei em dois casos. Ao fazer isso os sábios acabaram descobrindo que muitas leis, ou pelo menos trechos delas, pareciam ser contraditórias entre si. Em alguns casos a contradição é evidente e facilmente notada; em alguns casos a contradição só surge quando se olha mais atentamente para a linguagem utilizada pelo texto.

Quando a contradição é entre duas partes de uma mesma mishná, o Talmud apresenta a contradição usando a expressão huh gufa kashiá (הוא גופא קשיא, isso é em si mesmo uma dificuldade). Por exemplo:

Mishná: Se há dez pessoas [que comeram], diz-se nevarêch leElohênu (abençoemos nosso Deus) [...] Dá na mesma se são dez ou dez mil. Se há cem pessoas, diz-se nevarêch laHashem Elohênu (abençoemos o Eterno, nosso Deus) [...] Se houver mil pessoas, diz-se nevarêch leHashem Elohênu, Elohê Israel (abençoemos o Eterno, nosso Deus, Deus de Israel) [...] Se houver dez mil pessoas, diz-se nevarêch leHashem Elohênu, Elohê Israel, Elohê haTsevaôt ioshêv hacruvim (abençoemos o Eterno, nosso Deus, Deus de Israel, Deus das hostes, que habita entre os querubins) (Berachot 7:3).

Talmud: huh gufa kashia (isso é em si mesmo uma contradição). Primeiro foi dito que dá na mesma se são dez ou dez mil, o que parece indicar que ambos os casos são iguais; e depois o texto diz que com cem pessoas se diz tal e tal coisa; com mil pessoas se diz tal e tal coisa; com dez mil pessoas diz tal e tal coisa, etc. O Rabi Iossef disse: Não se trata de uma contradição. Uma das frases expressa a opinião do Rabi Iossi, o Galileu, e a outra expressa a opinião do Rabi Akiva (Berachot, 50a).

Quando a contradição é entre duas mishnaiot distintas, ou entre uma mishná e uma beraita, o Talmud traz as palavras de uma mishná e a contradição é apresentada com a expressão ha tanan (eis que foi ensinado) ou vehana tania (e eis que assim foi ensinado); ou ainda urminêhu (compare-as; confronte-as). Depois disso vêm as palavras que são consideradas uma contradição. Quando a contradição não é de caráter fundamental e decisivo, o Talmud pergunta 
mahí shaná? (qual é a diferença?).

Mishná: A partir de que momento pode-se ler a Shemá de noite? (Berachot 1:1).

Talmud: O Mar disse: do momento em que os sacerdotes entram para comer a sua terumá. Urminêhu (confronte-as). A partir de que momento pode-se ler a Shemá de noite? Do momento em que o pobre entrar em casa para comer o seu pão com sal (Berachot 2b).

Mishná: Se uma pessoa traz uma carta de divórcio e a perde - se logo em seguida ele a reencontra, é válida; se não, é inválida (Guitin 3:3).

Talmud: O Rabi Zera apontou uma contradição entre a nossa Mishná e uma Beraita, e a explicou: Tanan (foi ensinado): Se uma pessoa traz uma carta de divórcio e a perde - se logo em seguida ele a reencontra, é válida; se não, é inválida. Urminêhu (Confronte-as): Se a pessoa encontrou uma carta de divórcio para uma certa mulher na feira, ela deve ser entregue à mulher sempre que o marido atestar que ela é genuína; mas se o marido não atestar isso, não se entrega a carta nem para ele e nem para ela. Nós aprendemos que toda vez que o marido atesta que a carta é genuína, ela é entregue à esposa, então obviamente o mesmo vale mesmo que se tenha passado muito tempo! Ele [o Rabi Zera] explicou: Lá [na Mishná que diz que depois de um tempo a carta é inválida] trata-se de um local por onde passam frequentemente caravanas; mas aqui trata-se de um local onde as caravanas não passam frequentemente (Bava Metsia 18b).

Mishná: Se uma pessoa pretende levar [um objeto] em frente a ela, mas ele passa para trás dela, ela está isenta. Se ela quis levar o objeto às suas costas, e ele passou para a frente, ela é culpada (Shabat 10:4).

Talmud: Mahí shaná? (Qual é a diferença?) de querer carregar em frente, e ele ir para trás, para que a pessoa não seja culpada? Aparentemente, porque sua intenção não foi cumprida. Mas se é assim, quando a pessoa o leva às costas e o objeto passa para a frente, sua intenção também não foi cumprida! O Rabi Elazar disse: É uma contradição, quem ensinou uma delas não ensinou a outra (Shabat 92b).

A explicação deste último caso é o seguinte: a pessoa que pretende levar um objeto de 
um domínio particular para um domínio público no dia de Shabat é culpada de transgredir o dia sagrado, por ter a intenção de fazer isso. O Talmud pergunta: por que motivo se a pessoa queria levar o objeto na frente dela e o objeto acabou indo para trás ela não é culpada? Ela também tinha a intenção. Aliás, o mesmo vale para o caso inverso, se a pessoa queria levar o objeto às suas costas, e ele passou para frente. Em ambos os casos o regulamento devia ser o mesmo; ou a pessoa é isenta porque não tinha intenção, ou ela é culpada, por ter a intenção. O Rabi Elazar explica que, de fato, trata-se de uma contradição e que cada ensinamento foi dado por uma pessoa diferente, e não pela mesma pessoa. Ou seja, o sábio tanaíta que enunciou a primeira opinião não é o mesmo da segunda opinião.

As maneiras que o Talmud usa para resolver as contradições são diversas, mas, em geral, o Talmud explica uma diferença que existe entre os casos aparentemente contraditórios elucidando por que eles não se contradizem de fato; ou, em alguns casos (como no abordado aqui), conclui-se que cada ensinamento foi dito por um Sábio diferente, e que eles tinham opiniões divergentes entre si. ${ }^{92}$ Este último caso, em geral, é trazido com a seguinte formulação linguística lo cushia... can.... ve can.... (não é uma contradição, aqui se trata disso... e aqui se trata disso...).

Um dos meios mais tradicionais que o Talmud utiliza para resolver contradições entre duas mishnaiot, ou entre uma mishná e as palavras de um sábio amoraíta, é colocar a mishná como atuante frente a um caso particular, mais restrito do que o caso geral que se tem em mente, de modo que as duas fontes originais não se contradigam, mas apenas no que diz respeito ao caso particular. Esse meio de resolver contradições é chamado okimuta (אוקימתא), uma palavra aramaica que significa "colocação".

Sobre a okimuta, Zilberg escreve:

\begin{abstract}
"Ao observar o fato, parece que a "colocação", muitas vezes, é apenas um atalho, que conduz da lei da mishná cuja fonte é anônima, por meio do caso especial em que ela é "colocada", a um novo princípio - abstrato - que surge dela. O que se vê é que esta condensação das coisas exige uma expansão; pois toda abstração é uma ampliação dos limites, pois ela desprega a lei do tecido concreto da lei controversa" (Cach darcô shel haTalmud, p. 20).
\end{abstract}

Vale ressaltar que, muitas vezes, a okimuta é o jeito mais simples, e, talvez, o único, de explicar a mishná. Assim, por exemplo, ocorre no caso da seguinte mishná:

\footnotetext{
92 É importante notar que o Talmud não "prova” as hipóteses lançadas. Então quando um sábio afirma que as duas opiniões são de sábios diferentes, por exemplo, não existe prova textual alguma que leve a essa conclusão.
} 
Se um homem confia os produtos da terra às mãos de seu vizinho, o vizinho pode [ao devolver o produtol fazer deduções pela perda: trigo e arroz, nove meios de cavs $^{93}$ por cor $^{94}$ (Bava Metsia 3:7).

Quando o vizinho vai devolver as frutas ou cereais ao dono original, depois de ter cuidado delas, ele não precisa devolver o mesmo valor recebido do primeiro, pois presume-se que pode ter ocorrido uma perda de alimento, como, por exemplo, no caso de animais como ratos que comeram uma parte da produção. A mishná então define qual quantia pode ser deduzida no caso de diferentes tipos de produtos.

O Talmud desta passagem explica que isso se aplica somente quando três condições forem válidas: que o vizinho tenha recebido o produto ainda jovem, que o vizinho que recebeu o produto tenha misturado aquilo com seu próprio produto; e que, posteriormente, ele não saiba mais o que é a sua produção e o que é a produção da pessoa que lhe pediu para guardá-la.

Essas são condições que não derivam da mishná, e nem podem ser depreendidas da forma com que ela foi escrita. Mas, ao mesmo tempo, percebe-se que não é possível entender a mishná de outro modo, pois se a pessoa dá ao seu vizinho uma medida específica de alguma coisa, por exemplo, um saco de trigo, não faz sentido dizer que depois o vizinho pode deduzir 2,5\% da produção, conforme a lei, e devolver apenas 97,5\% de trigo. Então é bastante óbvio pensar que se uma quantidade específica de alimento foi dada ao vizinho, ou um recipiente fechado, por exemplo, é esta mesma quantidade que deveria ser devolvida.

Assim, o Talmud explica que a lei trazida aqui se aplica em um caso específico, no qual o vizinho misturou os produtos que lhe foram dados e que depois ele não se lembra mais o quê era de quem. Isto é uma okimuta, uma "colocação" da mishná, fazendo com que ela seja válida apenas em um caso específico. E é este recurso que muitas vezes se utiliza para resolver contradições. Por exemplo:

Se uma pessoa coloca um jarro em um terreno público e outro vem, tropeça e quebra o jarro, ele está isento [de pagar pelos danos] (Bava Qama, 3:1).

O Talmud pergunta: Por que isento? A pessoa não tem que olhar por onde anda? (Bava Qama, 27b). E ao responder a esse questionamento, o Talmud "coloca" a mishná em

\footnotetext{
${ }^{93}$ Cada cav pode equivaler a 1,2; 1,38 ou 2,4 litros dependendo da opinião rabínica.

${ }^{94} \mathrm{O}$ cor equivale a 248,8 litros.
} 
casos e contextos específicos, como, por exemplo, se isso ocorreu no escuro, ou se o vaso estava numa quina e a pessoa dobrou a esquina sem poder ver o vaso. Assim, consegue-se resolver a contradição entre as ideias - de que seria lógico a pessoa pagar pelo jarro quebrado, pois ela deveria olhar por onde anda,-- e a ideia da mishná, de que o jarro não deve ser pago.

No entanto, há casos em que o Talmud realmente conclui que o trecho em questão se trata de uma contradição insolúvel, e que as mishnaiot realmente são contraditórias, tendo sido ensinadas por dois sábios diferentes. No entanto, o Talmud evita fazer isso a qualquer custo e vê nessa solução uma atitude extrema e de último recurso. De modo geral, um sábio amoraíta prefere sempre achar outro tipo de resposta para explicar a aparente contradição. Prova disso é, por exemplo, o que diz o Reish Lakish: quando leis de uma mishná se contradizem entre si, é melhor dizer que elas discutem casos diferentes do que dizer que dois sábios diferentes as ensinaram (Kidushin 63b). Ou seja, o que o Reish Lakish defende é que é preferível usar uma okimuta, ou dizer que cada mishná está tratado de uma coisa, do que dizer que ambas falam da mesma coisa e realmente se trata da opinião de dois sábios que discordam entre si.

Outro método usado pelo Talmud para resolver contradições é concluir que chissurê mechserá ve achi catanê (חסורי מחסרא והכי קתני, estão faltando palavras, e o texto dever ser lido assim), ou seja, os sábios do Talmud concluem que a mishná não está clara o suficiente, e eles vêem a necessidade de adicionar as palavras faltantes, ou o trecho faltante. A respeito de quanto o Talmud Babilônico usa a chissurê mechserá, pode-se dizer que
esse método é utilizado quase sempre para resolver uma contradição entre duas fontes,
e, especialmente, dentro da própria mishná. Isso é feito por meio da compreensão do
Talmud Babilônico no que diz respeito à interpretação das fontes. O uso da chissurê
mechserá é visto principalmente nos locais em que o Talmud Babilônico pergunta: "é
um caso de contradição"?
(Goldberg, A. Derachim shel tsimtsum machloket etsel amoraei Bavel, Mechakrê
Talmud, p. 146).

Como explicar, então, que os sábios amoraítas se vêem no direito de explicar um trecho "faltante" da mishná? Como os amoraítas podem completar o que está faltando segundo o que lhes parece mais lógico?

Os sábios de Israel divergem quanto ao significado da expressão "faltante". Há os que dizem que realmente falta um trecho na mishná e que o Talmud vem para completar a lacuna; e há os que dizem que isso significa que a mishná está resumida e abreviada no modo em que foi escrita, e que o Talmud vem para explicar a abreviação e ampliar o texto em sua linguagem.

(Melamed, Mavô le Sifrut ha Talmud, p. 52).

Especificamente falando da omissão no texto da mishná, pode-se dizer que isso se deve a um erro ou esquecimento do Sábio tanaíta: o Sábio tanaíta se enganou na versão transmitida, ao ter omitido uma palavra por conta do esquecimento (Rashi, San'hedrin 10b, sobre o termo veha). 
Segundo o Rabenu Bechaie, jamais se trata de uma omissão de fato, mas sim de uma aparente omissão: e depois disso a sabedoria foi ficando escassa [...] e por isso o Talmud fala a respeito da Mishná: chissurê mechserá veachi catanê (חסורי מחסרא והכי קתני, estão faltando palavras, e o texto dever ser lido assim). A intenção não é dizer que a Mishná tem uma parte faltando, de modo algum, Deus nos livre, mas sim que ela parece ter uma parte faltando aos nossos olhos por causa da deficiência do nosso intelecto, porque nós não conseguimos chegar à profundidade da sabedoria da geração dos sábios da Mishná (Rabenu Bechaie, Biur al haTorá, Êxodo 34:27).

Vejamos um exemplo disso na prática:

Mishná: Pode-se comer e beber casualmente fora da sucá. Certa vez trouxeram um cozido para o Rabi Iochanan ben Zacai provar, e para o Raban Gamliel trouxeram duas tâmaras e um cântaro de água, e eles disseram para levar aquilo para dentro da sucá.

Talmud: É um caso de contradição? [A mishná diz que se pode comer casualmente fora da sucá, mas, mesmo assim, o Raban Gamliel exigiu que duas tâmaras e um pouco de água fossem levados para dentro da sucá]. Estão faltando palavras, e o texto dever ser lido assim: se a pessoa quiser ser mais severa quanto à lei, ela pode, e não precisa temer ser taxada de presunçosa; e isso também se aplica no caso do Rabi Iochanan ben Zacai, e o cozido que trouxeram para que ele provasse (Sucá 26b).

\subsubsection{Revisão da Mishná}

No processo de difusão e de transmissão da Mishná para fora de Israel, em especial para Babilônia (centro intelectual rabínico por muito tempo) ${ }^{95}$, acabaram ocorrendo distorções no texto. Assim, os amoraítas não deixaram de revisar e corrigir constantemente os textos da Mishná que chegavam até eles, baseando-se nas tradições que tinham recebido.

Em geral, as revisões consistiam em mudanças numa expressão ou em palavras da

\footnotetext{
${ }^{95}$ Segundo Rainer Albertz (Israel in Exile), o exílio da Babilônia ocorreu em 609 a.e.c., sem nunca ter se encerrado oficialmente, já que muitos judeus passaram a viver no país até tempos modernos. Durante o período dos gueonim (600 a 1000 e.c.) ainda havia grandes ieshivot e rabinos na Babilônia, em especial nas cidades de Sura e Pumbedita. Assim, pode-se afirmar que por cerca de 15 séculos a Babilônia foi importante centro intelectual rabínico.
} 
Mishná. Na maior parte das vezes isso é feito usando a expressão sami mican (apague daqui), ou seja, não se deve ler esta palavra na Mishná. Em alguns casos, uma variante dessa revisão chega a propor uma mudança das palavras ou das ideias expressas na mishná.

Segundo Epstein (Mavô Lenussach Hamishná, 2, p. 509), em geral a expressão tanê, quando aparece no Talmud, sempre introduz uma revisão feita pelos amoraítas. Mas ao analisar as diversas ocorrências dessa palavra, o mais correto parece ser dizer que, em alguns casos, ela traz meramente uma explicação e/ou interpretação do texto.

Nesse processo maior de revisão, muitas vezes ocorre um fenômeno menor, que pode ser chamado de "troca", isto é, os amoraítas trocam a ideia de dois tanaítas, fazendo com que a ideia de A passe a ser a ideia de B, e a ideia de B passe a ser a de A. Em grande parte dos casos essa troca é feita para resolver uma contradição entre duas mishnaiot, ou entre uma mishná e uma beraita. Mas há caso em que a troca é feita simplesmente porque um Sábio afirma ter aprendido que o ensinamento original era daquele jeito, e não do jeito mencionado na Mishná. Vale ressaltar, ainda, que na maioria dos casos em que a troca é proposta como meio de resolver uma contradição, isso não é aceito pacificamente pelos outros sábios, e, via de regra, o Talmud segue discutindo e propondo outras soluções menos "polêmicas".

Os amoraítas tinham, como visto, princípios gerais estabelecidos para definir a lei quando havia divergência entre os Sabios. Um desses princípios é dizer que a lei em um assunto específico segue sempre a opinião de um certo sábio tanaíta. Por exemplo, nas disputas entre o Rabi Eliezer e o Rabi Iehoshua, os sábios determinaram que a lei é sempre conforme o Rabi Iehoshua. Assim, existem casos em que uma ideia citada como sendo do Rabi Eliezer, e que os sábios queriam definir como a lei estabelecida, passou pelo processo de "troca", e foi colocada na boca do Rabi Iehoshua, como se ele tivesse sido o seu enunciador original. Por outro lado, as palavras do Rabi Iehoshua são postas na boca do Rabi Eliezer, e, assim, são rejeitadas.

O Rabi Iossi ben Chanina disse em nome do Rabi Huna: Em todo este capítulo, a lei é conforme a Escola de Hilel, exceto no local em que ela foi enunciada conforme a Escola de Shamai. O Rabi Oshaia, no entanto, trocou o ensinamento (fez com que o ensinamento da Escola de Shamai fosse enunciado pela Escola de Hilel) e então este ponto da lei também passou a seguir a Escola de Hilel.

(Berachot 52b) 
Sabe-se que, além do texto da Mishná, os amoraítas tinham também conhecimento de outros grupos de leis em suas mãos, o que se chama de Beraita (Cf n. 64 supra). Embora a Mishná fosse a forma estabelecida, usada e ensinada nas escolas e casas de estudo, muitas vezes os sábios também utilizavam estes textos externos e paralelos para servir de parâmetro de comparação com o texto fundamental da Mishná. Esta comparação servia para que eles fizessem acréscimos ao texto, comparassem opiniões divergentes, tentassem superar debates de ideias etc. Existem até mesmo casos em que o texto da Mishná é abandonado totalmente em prol do texto da Beraita.

Vamos ver um caso em que a Mishná é explicada com base em uma beraita.

Mishná: Se um homem leva as ovelhas para um curral e tranca a porta corretamente, mas mesmo assim as ovelhas fogem e causam algum prejuízo - ele não é responsável. Se, no entanto, ele não trancou a porta corretamente - ele é responsável (Bava Qama 6:1).

Talmud: Os sábios ensinaram (essa expressão geralmente é usada quando o Talmud vai trazer uma beraita): O que significa 'corretamente' e o que significa 'não corretamente'? Se se tratava de uma porta que consegue resistir ao vento, isso é corretamente. Se é uma porta que não consegue resistir ao vento, isso não é corretamente (Bava Qama 55b).

Na maioria das vezes, a Beraita é usada para entender uma Mishná porque os sábios acham que ambos os textos estão falando da mesma coisa, embora com linguagem diferente. No entanto, há casos em que os sábios concluem que a Beraita e a Mishná são realmente contraditórias entre si e, nestes casos, em geral, a Beraita é rejeitada. Mas, há casos em que ocorre justamente o inverso. Por exemplo:

Mishná: O que leva para fora [para o domínio público, no dia de Shabat] o equivalente ao feno que cabe na boca de uma vaca [...] é culpado [e deve oferecer um sacrifício] (Shabat $7: 4)$.

Talmud: Mas foi ensinado [em uma beraita] que a quantidade é a de figo seco [e não de feno] (que cabe na boca de uma vaca). Os dois padrões de medida são um e o mesmo. 


\section{Outro exemplo:}

Mishná: Em uma sinagoga que foi destruída [...] e na qual cresceu mato, o mato não pode ser cortado, para induzir o pesar de alma (Meguilá 3:3).

Talmud: Mas foi ensinado: O mato não pode ser cortado e dado como alimento [para os animais], mas ele pode ser cortado e deixado ali! (Meguilá 29a).

A Mishná diz que se uma sinagoga foi destruída e no terreno começou a crescer mato, é proibido arrancá-lo, porque as pessoas verão aquilo, ficarão pesarosas e se mobilizarão para reerguer a sinagoga. Mas a Beraita diz que de fato é proibido cortar o mato se o intuito for usálo para alimentar os animais, mas que é permitido cortar o mato e deixá-lo no mesmo local. O Talmud rejeita a ideia de que haja uma contradição entre a Beraita e a Mishná, e afirma que na Mishná a intenção também era dizer que é proibido cortar o mato e dar de comer para o animal, mas que não há proibição de cortar e deixar o mato ali.

\subsubsection{Identificação de Mishnaiot}

É muito comum que uma mishná seja trazida de forma anônima, sem identificar de quem é a opinião nela expressa. Em geral, o Talmud considera que esse tipo de mishná reflete a opinião geral, um consenso, e não a ideia de apenas um sábio. Mas há casos em que uma mishná "anônima" não reflete a opinião de todos, ou da maioria, e então o Talmud diz: matnitin velo ki ahi tana (nossa mishná não segue a opinião deste sábio tanaíta), ou matnitin velo kerabi P’loni (a mishná não é conforme o sábio tal e tal).

Então, em diversos casos o Talmud tenta identificar quem foi o indivíduo que expressou certa opinião, ou de quem é a opinião discordante da ideia principal sendo seguida. Obviamente, em muitos destes casos há uma discussão entre os amoraítas, pois cada um defende que o sábio tanaíta autor de certo dito é outro. Há muitos casos em que o identificar uma mishná anônima como sendo de um certo sábio se torna um recurso utilizado pelo Talmud para dar preferência àquela ideia na aplicação da lei, em detrimento das outras. 
com sua carga, que se rasgou - a pessoa é responsável pelo animal, mas isenta dos objetos inanimados (Bava Qama, 5:6).

Talmud: Esta mishná não é conforme o Rabi Iehudá, pois foi ensinado: O Rabi Iehudá considera responsável a pessoa que causou danos a um objeto inanimado que caiu em um buraco (Bava Qama 53b).

Segundo o sábio da mishná anônima, o homem que cavou um buraco não tem responsabilidade por danos causados a instrumentos ou a uma carga que caiu ali dentro. Isso porque ele entende o versículo Êxodo 21:33 - "E quando um homem abrir um poço, ou quando cavar um poço e não o cobrir, e um boi ou um asno cair ali" - como referência exclusiva a um animal.

E, por outro lado, o Rabi Iehudá discorda disso. O Talmud então estabelece que esta mishná não é a sua opinião.

Mishná: Se ele (o fogo) passou por uma cerca com mais de quatro amot, uma estrada pública, ou um rio, a pessoa (que acendeu o fogo) está isenta (Bava Qama 6:4).

Talmud: Estrada pública. Quem foi o tanaíta (que ensinou isso)? O Raba disse: Foi o Rabi Eliezer, como aprendemos: O Rabi Eliezer disse: Dezesseis cúbitos em uma rua pública (está isento) (Bava Qama 61a).

Algumas vezes os amoraítas encontram na mishná uma ideia trazida sem qualquer nome (e, que parece, portanto, ser uma ideia que expressa a opinião da maioria) mas que discorda, ou refuta, outra ideia trazida em outra mishná, em nome de um tanaíta específico. Para evitar erros e ter que afirmar que realmente existe uma divisão de ideias entre a mishná anônima e a mishná do sábio específico, os amoraítas levantam a hipótese de que a mishná, na verdade, foi dita por outro sábio, e não aquele mencionado a princípio. Exemplo:

Mishná: Tudo é abatido. Sempre se abate (Chulin 1:2).

Talmud: Sempre se abate. Quem foi o sábio tanaíta que ensinou isso? O Raba disse: O Rabi Ishmael. "Quando o Eterno, teu Deus, aumentar o teu território, como te falou, e disseres: 'Comerei carne', porquanto a tua alma desejará comer carne; com todo o desejo de 
tua alma poderás comer carne" (Deuteronômio 12:20) permite o consumo de carne em geral. No deserto, a carne em geral era proibida. Quando Israel entrou na Terra de Israel, ela foi permitida. Depois que eles foram exilados, alguém poderia pensar que ela foi proibida novamente. Portanto, a mishná ensina que nós podemos fazer o abate mesmo hoje em dia. $O$ Rav Iossef perguntou: Se é assim, por que a mishná diz "sempre se abate”? Ela deveria dizer "sempre se abate e se come"! O Rav Iossef disse: No começo a carne em geral era proibida porque Israel se encontrava perto do Tabernáculo; depois a carne em geral foi permitida porque eles estavam longe do Tabernáculo. Então isso se aplica ainda mais no exílio, onde a pessoa não pode oferecer um sacrifício e, portanto, a carne em geral deve ser permitida! Não há necessidade de ensinar isso. O Rav Iossef disse: A mishná é conforme o Rabi Akiva. Uma beraita [do Rabi Akiva] foi trazida: "Se estiver longe de ti o lugar que escolher o Eterno, teu Deus, para ali pôr o Seu Nome, poderás degolar do teu gado e do teu rebanho" (Deuteronômio 12:21) vem para proibir um animal morto por "rasgo" (corte largo demais). No deserto animais mortos por rasgo eram permitidos. Quando Israel entrou na Terra de Israel, isso foi proibido. Uma pessoa poderia pensar que no exílio isso foi permitido novamente. A mishná ensina que não é assim, e que sempre deve ser feito o abate (Chulin 16b-17a).

O Talmud aqui tenta entender por que a mishná precisou escrever a expressão "sempre se abate". "Por acaso poderia ser de outro modo?" é a pergunta que intriga os sábios do Talmud. Então, eles perguntam quem foi que ensinou aquilo, e a primeira resposta dada é que foi o Rabi Ishmael. Em seguida, o Sábio que respondeu que foi o Rabi Ishmael explica o que ele quis ensinar. Em seguida o Rav Iossef discorda dessa ideia, e alega que foi o Rabi Akiva quem ensinou isso e, como o Sábio anterior, ele argumenta por que acha isso e qual era a intenção do Rabi Akiva. Aqui se trata de um caso, então, em que os sábios estão preocupados em definir quem foi que ensinou certa lição - "sempre se abate" - pois isso define como a lei foi aprendida e, portanto, muda qual será a lei de fato e a explicação dada para aquilo. 



\section{A ESTRUTURA DO TALMUD}

Para que o diálogo entre sábios tanaítas e amoraítas pudesse ocorrer de forma mais fluida, os editores do Talmud se utilizaram de alguns artifícios de edição. Um deles diz respeito ao próprio conteúdo do Talmud e o outro diz respeito à disposição dos elementos na página impressa.

\subsection{Estrutura do conteúdo do Talmud}

Todo trecho do Talmud que lida com um assunto específico é chamado suguiá (סוגיא). Não existe um critério objetivo para definir onde começa e termina uma suguiá e a divisão é feita de maneira bastante subjetiva e, diga-se de passagem, intuitiva. Por conta dessa falta de objetividade também não existe uma maneira exata de definir quantas suguiot existem no Talmud.

Mesmo assim, existe um consenso geral entre os estudiosos do Talmud do que constitui uma suguiá típica, e quais são os elementos que, em geral, se podem esperar encontrar nela. Esses elementos costumam ser categorizados pela função que desempenham no texto dos sábios e, em grande parte dos casos, podem ser reconhecidos pelas palavras iniciais de sua formulação (embora, nem sempre).

É esse tipo de conhecimento que permite ao estudioso do Talmud saber, por exemplo, quando ele está lendo uma pergunta ou uma resposta dos sábios. É isso que lhe permite identificar também se a informação sendo trazida é de um sábio tanaíta, de um sábio amoraíta ou de uma fonte externa à Mishná (beraita). Como o texto do Talmud não possui pontuação gramatical como estamos acostumados nos dias de hoje, sem esse tipo de conhecimento básico da estrutura talmúdica fica quase impossível ler e compreender a discussão que está ocorrendo. Adiante (item 8.3.) pode-se ver como o texto do Talmud é apresentado, de maneira contínua e corrida. 


\subsection{Estrutura típica da suguiá}

Em geral, uma suguiá começa, obviamente, com a explicação dos amoraítas para um trecho da Mishná. Em meio a esta explicação, outros sábios colocam uma série de perguntas, dúvidas e problemas. Em algum ponto da suguiá tenta-se apresentar respostas a essas perguntas e resolver eventuais contradições ou dúvidas que tenham sido apontadas. Por fim o Talmud encerra a discussão em questão citando a decisão legal final (a halachá) e as implicações dessa decisão.

Assim, são quatro os elementos gerais de uma suguiá:
1) Explicação da Mishná
2) Perguntas, dúvidas e problemas
3) Respostas às perguntas, dúvidas e problemas
4) Conclusão final e decisão da lei

Mais especificamente, no entanto, costuma-se dividir os elementos constituintes da suguiá em dez partes.

1) Explicação da Mishná, chamada de Perush, e analisada em detalhes no item 7.3 acima.

2) Afirmação amoraíta, chamada de shematata (שמעתתא), geralmente apresentada pela palavra itmar (אתמר), "foi dito".

3) Perguntas e respostas sobre a lei, apresentadas com uma das expressões: ibaiê lehu, baê mineia, bau mineia (perguntaram-lhes, perguntou-lhe, perguntaram-lhe).

4) Apresentação de dificuldade (cushiá, קושיא), ou seja, uma pergunta com intuito de refutar uma afirmação talmúdica ou sua lógica subjacente. Em geral, introduzido com a expressão matkif le (מתקיף לה), "ele o atacou [com uma pergunta]".

5) Ajuda ou suporte a uma opinião, chamada de siúa (סיוע). Trata-se sempre de fonte tanaíta (mishná, beraita ou tossefta) citada para corroborar uma visão amoraíta. Em geral apresentada com a expressão tania kevatê (תניא כוותיה), "aprendemos algo similar".

6) Contradição entre tanaítas ou versículos da Torá, chamada remiá (רמיא). Como no item anterior se apresentam fontes tanaítas, às vezes o elemento seguinte nota uma 
contradição entre elas, mencionando com a expressão veriminêhu (ורמינהו), que significa, literalmente, "lançamos uma [fonte] contra a outra".

7) Explicação do motivo pelo qual se repetiram partes similares ou idênticas. Às vezes não é uma contradição nas fontes tanaítas o que se nota, mas sim uma repetição, aparentemente desnecessária. Quando isso ocorre, os amoraítas tentam explicar a necessidade da repetição (hatsrachá, הצרכה). Introduzida por expressões como tserichá e tserichê (é necessário, são necessários).

8) Decisão legal (halachta), geralmente vindo ao final da discussão da suguiá, e depois de dirimidas todas as dúvidas e dadas todas as explicações necessárias. Apresentada como vehalachta ("e a lei é").

9) Exemplificação de caso real que envolva a lei, por vezes vindo logo antes ou logo depois da definição da lei, com o intuito de corroborá-la. Usa-se a expressão maassê (um caso real) ou hava uvda (“ocorreu certa vez"), e relata-se o evento.

10) Ensinamento através de alegorias e histórias, agadta (אגדתה). Igual ao caso anterior, às vezes mencionado logo antes ou logo depois da decisão legal, para corroborála. No entanto, aqui se trata de uma história moral, não baseada necessariamente em fatos reais. Reconhecida por, em geral, citar um versículo e explaná-lo de maneira alegórica. 

(marcações minhas).

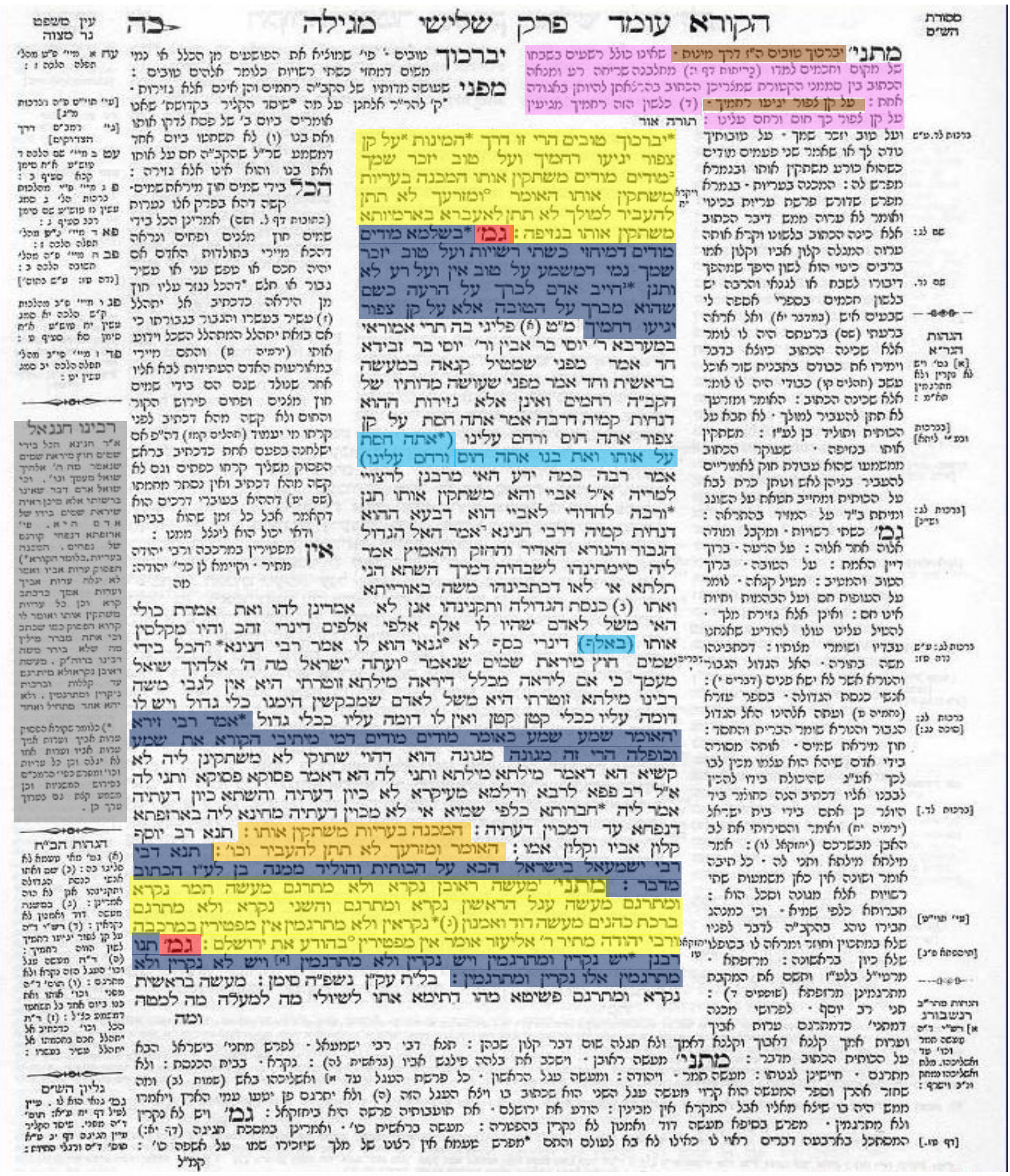


No topo da página temos as marcas que permitem identificá-la. Da esquerda para direita, temos: número da página (25a), nome do tratado (Meguilá), número do capítulo (terceiro capítulo) e nome do capítulo (hacorê omed, aquele que lê de pé).

Tudo que está no centro da página em letra de forma é o Talmud propriamente dito. Dentro dessa área textual temos diversas partes:

1. A mishná, marcada em amarelo. No topo da página temos uma mishná que é a continuação do que está na página anterior, 24b. Mais abaixo, temos uma nova mishná, começando com a abreviação matni (מתני) de matnitin (מתניתין).

2. Parte da mishná, marcada em laranja. O Talmud desmembra a mishná parte por parte, na sequência textual. Assim, sempre que um trecho terminou de ser analisado e um novo começará a ser discutido, o Talmud cita a parte da mishná que será foco da interpretação no momento. Isso só não é feito na primeira vez, pois é lógico que o Talmud está discutindo, então, o começo da mishná.

3. Talmud. Depois da mishná, aparece a abreviação Guem (גמ), em vermelho, indicando que se trata do início da Guemará. Depois dessa marcação começa a discussão talmúdica, a verdadeira essência do Talmud. Nessa parte vemos, muitas vezes, citações de fontes sem mencionar que fontes são essas e, obviamente, muitas vezes essas fontes citadas são amoraítas (sejam da mishná ou do texto que ficou fora dela, a beraita). Na página em questão marcamos essas menções em azul escuro. Ainda nessa parte é possível ver (sem marcação, logo após à última marcação em azul escuro), um pouco antes do final da página, um acróstico (בל"ת עק"ן נשפ"ה) seguido da palavra siman (oימן). Essas são marcas mnemônicas inseridas posteriormente (pelos Savoraím). Cada letra tem por objetivo remeter a um dos tópicos tratados nos diversos trechos do Talmud para ajudar a memorizar que temas são tratados na página em questão. Por fim, no texto do Talmud é possível achar palavras entre parênteses (marcadas em azul claro), ou entre colchetes (não há exemplo nessa página). As marcadas em parênteses são palavras que não estão nas fontes originais, e foram acréscimos. As marcadas em colchetes são

\footnotetext{
${ }^{96}$ Matnitin significa, "nós aprendemos" ou "nós estudamos" (em aramaico). Em geral é o termo que precede uma mishná no Talmud.
} 
palavras acrescidas para compreensão do texto talmúdico. Essas marcas foram feitas pelo Rabi Ieshaiáhu Berlin, no fim do século XVIII.

\subsubsection{Comentaristas}

Além do texto central, temos o texto marginal. Do lado direito dessa página (nas páginas opostas, do lado esquerdo - sempre do lado interno da página), temos os comentários do Rashi. Eles são organizados do seguinte modo: aparece uma citação da mishná ou do Talmud (marcada em marrom) e ela é analisada (em rosa), até os dois pontos. Entre as duas, para diferenciá-las, se coloca um círculo preenchido. Cada comentário do Rashi é chamado dibur e é mencionado com suas palavras iniciais. Por isso, eles são citados com a sigla ד"ה de dibur hamatchil (דיבור המתחיל).

Do lado esquerdo dessa página (direito das páginas opostas, e sempre do lado externo) temos os Tossafot. A apresentação dos comentários é similar à do Rashi (citação, círculo preenchido, comentário, dois pontos). Cada trecho também é chamado dibur e é citado como no caso dos diburim do Rashi.

Às margens da página, mais para fora dos comentários do Rashi e dos Tossafot, se encontram outros comentaristas de interesse, que podem variar segundo a edição do Talmud. Os mais citados são o Rabenu Chananel [Tunísia, 990-1053] (marcado em cinza) e o Rav Nissim Gaon [Tunísia, 990-1062].

\subsubsection{Referências e revisões}

Além do texto central e seus comentários, o Talmud costuma ter ferramentas de auxílio ao estudioso: referências, revisões e notas. Analisaremos aqui apenas as principais ferramentas encontradas em uma página do Talmud, já que foge ao escopo do trabalho analisar minuciosamente a totalidade dessa imensidão de recursos.

1. Torá Or. Referências dos versículos do Tanach. São indicados por meio de um 
círculo vazio $\left(^{\circ}\right)$ no texto central do Talmud. Na página em questão, há quatro dessas referências.

2. Messorat Hashas [Tradição do Talmud]. Referência de textos paralelos na tradição talmúdica. Indicados por um asterisco, e a referência é posta à margem da página, em uma linha reta a partir do asterisco.

3. Ayin Mishpat Ner Mitsvá [Fonte de Justiça, Luz do Mandamento]. Referência a quatros livros de leis: Mishnê Torá (Rambam), Sêfer Mitsvot Gadol (Rabi Moshe Mekotzi, um tossafista); Tur (Rabi Iaacov Baal Haturim) e Shulchan Aruch (Rabi Iossef Caro). Indicados por uma letra reduzida, como que exponencial.

4. Hagahot Habach. Correções do texto do Talmud, do Rashi e dos Tossafot, feita pelo autor de Beit Chadash (daí o nome Bach). Indicado por uma letra na escrita de Rashi dentro de parênteses. É basicamente uma correção de cunho linguístico e filológico.

5. Em algumas partes dos tratados há Hagahot Hagra, escritas pelo Gaon de Vilna. Indicada com uma letra de imprensa em tamanho normal, ou, às vezes, com uma letra na escrita de Rashi dentro de colchetes. Em geral notas de explicação e esclarecimento do texto ou de algum aspecto legal.

\subsection{Tradução "plana" da folha mostrada (Meguilá 25a) ${ }^{97}$}

"Que os bons te abençoem” é um caminho de heresia. "Que tuas misericórdias alcancem o ninho de uma ave", "que teu nome seja mencionado pelo bem", "agradecemos, agradecemos", o silenciamos. Quem distorce as nudezes, o silenciamos. O que diz "E da tua descendência não darás nenhum para fazer passar pelo fogo perante Moloque" como "não darás nenhum para engravidar a uma gentia", o silenciamos com uma reprovação. GUEM Entendemos o "agradecemos, agradecemos", pois parece que são dois poderes. "Que teu nome seja mencionado pelo bem" também, pois parece que para o bem sim, e para o mal não. Nós aprendemos: o homem deve abençoar o mal assim como ele abençoa o bem. No entanto, "Que tuas misericórdias alcancem o ninho de uma ave", qual é o motivo? Houve divergência entre

\footnotetext{
${ }^{97}$ No item 8.5. pode-se ler a tradução crítica e comentada, que é de mais fácil entendimento. Aqui se colocou a tradução o mais "crua" e "plana" possível para que o leitor possa ter uma ideia do que experimenta o estudioso do Talmud ao ler uma página de um de seus tratados.
} 
dois amoraítas no Ocidente, o Rabi Iossi bar Abin e o Rabi Iossi bar Zevida. Um deles disse: porque instila inveja nos atos da criação. O outro disse: porque faz dos atributos do Santíssimo, bendito seja, misericórdias, sendo que são apenas decretos. Houve um homem que desceu diante do Raba e disse: "Tu tiveste misericórdia do ninho de uma ave, agora tem piedade e misericórdia de nós" (tu tiveste misericórdia do animal e de sua cria, agora tem piedade e misericórdia de nós). O Raba disse: "Quão bem esse aí sabe aplacar a seu mestre”. Abaiê lhe disse: "Mas não fomos ensinados que o silenciamos?". O Raba queria aguçar o Abaiê. Houve um homem que desceu diante do Rabi Chanina e disse: "O Deus grandioso, poderoso, temível, majestoso, forte e valente". Ele lhe disse: “acabaste de louvar a teu mestre? Agora, eis que os três primeiros, se não tivessem sido escritos por Moisés na Torá, e os homens da Grande Assembleia não os tivessem instituído, nós não o diríamos. E tu disseste tudo isso! Isso é como o homem que tinha milhares de milhares de milhares de dinares de ouro e que o louvavam dizendo que ele tinha milhares de dinares de prata. Isso não seria um insulto a ele?" O Rabi Chanina disse: "tudo está nas mãos dos céus, exceto o temor aos céus, pois foi dito: 'Agora, pois, ó Israel, que é que o Senhor teu Deus pede de ti, senão que temas o Senhor teu Deus"'. Podemos concluir um princípio de que o temor é algo pequeno? Sim. Para Moisés, nosso mestre, era algo pequeno. É como um homem a quem pedem emprestado um grande recipiente e ele o tem. Para ele vai parecer um pedido pequeno. Mas se lhe pedem um pequeno e ele não o tem, isso lhe parecerá um pedido grande. O Rabi Zeira disse: “Quem diz 'Ouve, ouve’ é como se dissesse 'agradecemos, agradecemos"”. Isso é uma objeção a "quem lê o Shemá e o dobra, faz algo repreensível". É repreensível, e o silenciamos? Não o silenciamos. Mas não há contradição. Num caso supomos que ele disse uma palavra, uma palavra. No segundo caso, supomos que ele diz um trecho, um trecho. O Rav Papa disse ao Raba: Mas talvez na primeira vez ele não pensou no que disse, e agora ele está pensando. Ele respondeu: é ele um colega dos céus? Se ele não pensa no que fala, baterei nele com um martelo de ferreiro até que passe a pensar. Quem distorce as nudezes, o silenciamos. O Rabi Iossef aprendeu: "a vergonha de seu pai, a vergonha de sua mãe". O que diz "E da tua descendência não darás nenhum para fazer passar" etc. Na escola do Rabi Ishmael foi ensinado: o texto fala de um israelita que veio sobre uma cutita e que teve um filho com ela para fins idólatras. APRENDA A história de Reuven é lida, mas não traduzida. A história de Tamar é lida e traduzida. A história do bezerro: a primeira é lida e traduzida, a segunda e lida mas não traduzida. A bênção sacerdotal e a história de David e Amnon são lidas mas não traduzidas. Não se lê a porção da carruagem como haftará. O Rabi Iehudá permite. O Rabi Eliezer diz: não lemos como haftará “faz saber a Jerusalém”. GUEM Nossos sábios ensinaram: há passagens que são lidas e traduzidas, e há as que são lidas mas não 
traduzidas. Há também as que não são nem lidas e nem traduzidas. Essas são as que são lidas e traduzidas: BLT EKN NSHPH é o sinal. Os atos da criação são lidos e traduzidos. Obviamente! Você poderia pensar que por isso perguntariam o que há acima, e o que há abaixo.

\subsection{Tradução crítica da folha mostrada (Meguilá 25a)}

O texto desse trecho do Talmud está discutindo o que são consideradas maneiras impróprias de louvar a Deus. Para isso, os sábios do Talmud se baseiam no texto da Mishná, que diz que dizer "Que os bons te abençoem” é um caminho de heresia, pois a pessoa está presumindo que apenas os bons devem abençoar a Deus.

Em seguida, a Mishná cita três casos em que uma pessoa deve ser silenciada - devese mandar que ela pare de falar. Se, referindo-se a Deus, a pessoa disser: "Que tuas misericórdias alcancem o ninho de uma ave", "que teu nome seja mencionado pelo bem" ou "agradecemos, agradecemos", o silenciamos.

A Mishná prossegue e diz que Quem distorce as nudezes, o silenciamos. As nudezes são a proibição chamada, em hebraico, de araiot. Trata-se de uma longa lista trazida em Levítico 18 mencionando quais são as proibições relacionadas à imoralidade sexual.

Nesse mesmo capítulo bíblico, há um verso que diz "E da tua descendência não darás nenhum para fazer passar pelo fogo perante Moloque" (Levítico 18:21). A proibição bíblica é com relação ao culto idólatra a Moloque, pelo qual se fazia passar uma criança pelo fogo. No entanto, a palavra "passar" (להעביר, lehaavir) em hebraico é muito parecida com a palavra "engravidar" (לעבר, leaber), o que permitiria que alguém lesse o versículo como "não darás nenhum para engravidar a uma gentia". Ou seja, a pessoa poderia ler o versículo como uma permissão de engravidar a uma gentia. Se a pessoa defender esse tipo de ideia, o silenciamos com uma reprovação.

Aqui termina o trecho da Mishná e, agora, os sábios do Talmud começam a discuti-lo. A primeira coisa sobre as quais eles se debruçam são os três casos que a Mishná cita como sendo obrigatórios de silenciar a pessoa. Os sábios afirmam: Entendemos o problema em dizer “agradecemos, agradecemos", pois parece que são dois poderes, e que se está agradecendo a dois deuses.

No caso de "Que teu nome seja mencionado pelo bem" também é fácil entender o problema, pois parece que para o bem sim, pode-se mencionar o nome de Deus, e para o mal 
não. Isso contradiz explicitamente um ensinamento da Mishná, trazido no Talmud com a palavra Matnitin (Nós aprendemos): o homem deve abençoar o mal assim como ele abençoa o bem.

A questão que os sábios colocam é: Qual é o problema em dizer "Que tuas misericórdias alcancem o ninho de uma ave"? Existe um mandamento, em Deuteronômio 22:6-7 que é justamente sobre o ninho das aves. Então o que haveria de errado em dizer que a misericórdia divina se estende até ali?

Duas respostas são mencionadas, em uma divergência entre dois amoraítas (sábios da época do Talmud) no Ocidente da Babilônia, ou seja, em Israel: o Rabi Iossi bar Abin e o Rabi Iossi bar Zevida.

Um deles disse: Dizer "Que tuas misericórdias alcancem o ninho de uma ave" instila inveja nos atos da criação, pois os outros animais não estão sendo mencionados como forma de louvar a Deus. Já o outro Sábio disse: dizer "Que tuas misericórdias alcancem o ninho de uma ave" é errado e um problema porque faz dos atributos do Santíssimo, bendito seja, misericórdias, sendo que são apenas decretos. Ou seja, a pessoa está dizendo que os mandamentos divinos são coisas boas, quando, na verdade, se tratam de leis que, por definição, estão acima do bem e do mal e que devem ser cumpridas independente de sua percepção humana, se boas ou más.

O Talmud conta um causo: Houve um homem que desceu diante do Raba e disse para Deus: "Tu tiveste misericórdia do ninho de uma ave, agora tem piedade e misericórdia de nós". Outra versão afirma que o homem teria dito: tu tiveste misericórdia do animal e de sua cria, agora tem piedade e misericórdia de nós.

O Raba, ao ouvir o homem rezando assim, disse: “Quão bem esse aí sabe aplacar a seu mestre". Abaiê, que estava presente à cena, junto ao Raba, lhe disse: "Mas não fomos ensinados que o silenciamos?". Ou seja, o Abaiê queria saber se o homem não teria feito um louvor impróprio a Deus e se, por isso, não devia ser silenciado. Os sábios do Talmud concordam que, sim, que foi impróprio o louvor do homem. Mas então por que o Raba teria dito que o homem sabia como aplacar a seu mestre? A opinião dos sábios é que O Raba queria aguçar o Abaiê, estava como que provocando seu aluno, para incitar-lhe a capacidade de reflexão.

Em seguida o Talmud cita um outro caso similar. Houve um homem que desceu diante do Rabi Chanina e disse: “O Deus grandioso, poderoso, temível, majestoso, forte e valente". A fórmula usada pelo homem não é de todo estranha. É comum na liturgia judaica encontrar trechos de louvor a Deus que dizem haEl hagadol haguibor vehanorá [Deus 
grandioso, poderoso, temível]. No entanto, como se pode ver, o homem não usou apenas esses três adjetivos comuns, e acrescentou mais três por sua própria vontade, totalizando em seis adjetivos qualificadores de Deus.

Ao ouvir isso, o Rabi Chanina disse ao homem: "acabaste de louvar a teu mestre? Agora, eis que os três primeiros adjetivos que tu usaste, se não tivessem sido escritos por Moisés na Torá (em Deuteronômio 10:17), e os homens da Grande Assembleia não os tivessem instituído (Neemias 9:32), nós não o diríamos, pois até eles podem ser considerados um louvor impróprio. E tu disseste tudo isso, usando seis adjetivos para falar de Deus! Isso é como o homem que tinha milhares de milhares de milhares de dinares de ouro e que o louvavam dizendo que ele tinha milhares de dinares de prata. Isso não seria um insulto a ele?" O Rabi Chanina viu o louvor do homem como impróprio pois ao enunciar adjetivos para descrever a Deus obviamente se está fazendo uma descrição aquém do que seria a realidade.

Desse ocorrido, O Rabi Chanina aprendeu uma lição e disse: "tudo está nas mãos dos céus, exceto o temor aos céus, pois foi dito: ‘Agora, pois, ó Israel, que é que o Senhor teu Deus pede de ti, senão que temas o Senhor teu Deus"' (Deuteronômio 10:12).

No sentido literal, o versículo de Deuteronômio parece dizer que existe apenas um mandamento que Deus dá ao povo de Israel. No entanto, isso por si só é contraditório, já que em diversas outras passagens da Bíblia aparecem um sem número de mandamentos e regulamentos a que os israelitas devem obedecer. Portanto, o Rabi Chanina entende esse versículo como prova de que apenas uma coisa é obrigação humana desenvolver: o temor aos céus. Todo o resto vem "sozinho", decorrente dessa ação única de desenvolver o temor aos céus. $\mathrm{O}$ homem se encarrega de desenvolver o temor aos céus, e o resto fica por conta dos céus propriamente dito.

Agora, da maneira com que o versículo foi escrito, dá a entender que o temor aos céus é algo pequeno e simples, um pedido banal e de pouca complexidade. Então o Talmud pergunta: Podemos concluir um princípio de que o temor é algo pequeno? A resposta é um Sim, mas um sim subjetivo, e relativo a cada pessoa. Para Moisés, nosso mestre, o temor aos Céus era algo pequeno.

Para entender a subjetividade da grandeza ou pequenez do temor aos céus, o Talmud faz uma comparação: É como um homem a quem pedem emprestado um grande recipiente e ele o tem. Para ele vai parecer um pedido pequeno. Mas se lhe pedem um recipiente pequeno e ele não o tem, isso lhe parecerá um pedido grande.

Voltando à discussão dos elogios indevidos, O Rabi Zeira disse: “Quem diz 'Ouve, ouve' [ao recitar o Shemá] é como se dissesse 'agradecemos, agradecemos"'. Na lógica do 
Rabi Zeira, se dizer "agradecemos, agradecemos" pode dar a entender que existem duas deidades, dizer “Ouve, ouve” na oração “Ouve, ó Israel” [Shemá] dá a mesma sensação.

Para provar que o raciocínio do Rabi Zeira pode estar certo, o Talmud cita uma beraita, que diz: "quem lê o Shemá e o dobra, faz algo repreensível”.

No entanto, um Sábio contesta essa prova. O texto da beraita diz apenas que o ato é repreensível, mas não que a pessoa deve ser silenciada, como nas outras menções da Mishná. Uma coisa é dizer que o ato é repreensível, a outra é dizer que a pessoa deve ser silenciada.

Tentando resolver a divergência ocorrida entre o Rabi Zeira e o texto da beraita, os sábios concluem que não há contradição, pois cada fonte está falando de um caso. Num caso, o da beraita, supomos que a crítica é porque ele (a pessoa rezando) disse uma palavra, uma palavra, repetindo um termo. A pessoa reza dizendo, por exemplo: Shemá Shemá Israel Israel em vez de Shemá Israel. No segundo caso, o caso do Rabi Zeira, supomos que ele recita um trecho, e repete um trecho. Por exemplo, a pessoa diz "agradecemos a ti" e "agradecemos a ti”, como se houvesse duas deidades. Assim, repetir um trecho, segundo o Rabi Zeira, seria motivo para silenciar a pessoa, tanto quanto ao dizer "agradecemos, agradecemos". Repetir as palavras, no entanto, seria apenas repreensível, segundo a beraita, sem que haja necessidade de silenciar a pessoa. Trata-se apenas de um jeito tonto e estranho de rezar, mas não de uma heresia que precisa ser silenciada.

O Rav Papa, no entanto, coloca uma pergunta ao Raba: Mas talvez na primeira vez ele não pensou no que disse, e agora ele está pensando. Ou seja, talvez a pessoa queira repetir um trecho todo da oração pois da primeira vez o leu de maneira mecânica e, na segunda, resolveu ler se concentrando mais. Mesmo assim esse seria um caso reprovável?

Ele, o Raba, respondeu: Por acaso é ele um colega dos céus? Ele considera que Deus é um amigo dele e que ele pode se repetir se não falou com Ele da maneira correta? Pessoas assim devem apanhar. Se ele não pensa no que fala, baterei nele com um martelo de ferreiro até que passe a pensar.

Sem outros questionamentos a fazer até aqui, os sábios selecionam novo trecho da Mishná para discutir: Quem distorce as nudezes, o silenciamos.

O que significa "distorcer as nudezes"? O que significa distorcer o sentido dessa passagem da Torá? O Rabi Iossef dá um exemplo do que aprendeu: a pessoa diz que "nudez de seu pai" e "nudez de sua mãe" se referem "a vergonha de seu pai, a vergonha de sua mãe", ou seja, aos órgãos sexuais do pai e da mãe, mas não ao ato de ter relações sexuais com eles. Se uma pessoa, portanto, diz que o texto bíblico está proibindo apenas a revelação dos órgãos sexuais do pai e da mãe, mas não o incesto, essa pessoa está pervertendo as palavras do texto e 
deve ser silenciada.

Sem mais nada a acrescentar sobre esse caso, o Talmud se debruça sobre outro trecho da Mishná: O que diz "E da tua descendência não darás nenhum para fazer passar" etc.

Como dito antes, seria possível deturpar o sentido do versículo e dizer que a proibição não é de passar uma criança pelo fogo, mas que se trata de uma permissão de engravidar uma gentia.

Os ensinamentos do Rabi Ishmael são frequentemente citados no Talmud, mas não fazem parte da Mishná, sendo, portanto, uma Beraita. O nome desse corpo de conhecimento é Taná debê Rabi Ishmael, que significa, literalmente, "o que foi ensinado na Casa de Estudos do Rabi Ishmael”. Nesse caso que está sendo discutido, os sábios trazem um ensinamento de lá: o texto fala de um israelita que veio sobre uma cutita e que teve um filho com ela para fins idólatras. O Rabi Ishmael acha importante explicar que, na verdade, o texto não quer apenas proibir o ritual idólatra de passar uma criança pelo fogo, mas também o fato de ter um filho com uma gentia para fins de idolatria. Assim, qualquer leitura desse versículo que não seja uma das duas oficiais, seria um motivo para silenciar a pessoa.

Desse ponto em diante o Talmud cita uma outra Mishná que, portanto, faz parte de uma outra série de discussões que se inicia e que não serão analisadas aqui. 



\section{CONCLUSÃO}

De tudo o que foi exposto pode-se concluir que a interpretação do texto da Torá é uma atividade legítima e necessária, como ocorre com qualquer texto que se pretenda código de leis. Para tanto, o grupo de pessoas que ficou comumente chamado de "sábios" se utilizou de métodos hermenêuticos e princípios reguladores para definir a lei religiosa.

Muitos dos métodos usados e da lógica empregada podem ser estranhas e até mesmo inaceitáveis para muitos. Neste ponto, é importante ressaltar algo que já foi mencionado, de que talvez as leis não foram criadas por conta dos métodos hermenêuticos, mas apenas que esses métodos eram empregados para explicar e fundamentar atitudes que já eram seguidas e consideradas prática correta entre os religiosos.

Se não for esse o caso, isto é, se a interpretação rabínica realmente surge no sentido de criar leis, é importante ressaltar algo óbvio mas que, muitas vezes, é esquecido pelas pessoas: os judeus hoje não seguem a religião conforme definido na Torá escrita, mas sim um conjunto de leis estabelecidas por sábios de diferentes épocas.

Assim, embora hoje se pretenda falar de "judaísmo" como um movimento íntegro, único e totalmente coerente, o emprego deste termo esconde uma realidade existente, a de que existem grupos “judaicos” que não seguem os ensinamentos daqueles sábios mencionados e, além disso, a religião seguida pelo povo hebreu havia milhares de anos, antes do advento da Mishná e do Talmud, certamente não era a mesma que a maioria dos judeus considera como correta hoje.

Para citar alguns exemplos de diferenças práticas acarretadas entre seguir puramente o texto das Escrituras e as interpretações dos sábios, podemos identificar, por exemplo:

- A questão de pertença ao povo judeu. Pela Torá, uma criança é judia se seu pai for judeu. A Halachá dos sábios definiu que isso é definido pela mãe (Kidushin 3:12, século II e.c.).

- Segundo a Torá, o não-judeu que deseja se filiar ao povo judeu pode fazê-lo sem maiores impedimentos. A Halachá dos sábios estabeleceu requisitos e regras para aqueles que desejam se converter ao judaísmo. 
- Pela Torá, se um animal é puro, basta fazer um abate qualquer para poder consumilo. A Halachá dos sábios estabeleceu regras específicas de abate para dizer se um animal puro é permitido para o consumo.

Curiosamente os próprios sábios discutem essa questão, já na época do Talmud: $O$ Rabi Elazar disse: A maior parte da Torá está contida na lei escrita, e só uma pequena parte dela foi transmitida oralmente... O Rabi Iochanan, por outro lado, diz que a maior parte foi transmitida oralmente e que apenas a menor parte está contida na lei escrita (Guitin 60b).

Segundo a visão do Rabi Elazar, a verdadeira lei estaria, em sua maior parte, escrita. Já o Rabi Iochanan, que parece ser a visão prevalecente hoje em dia, diz ao contrário, que o texto escrito é uma minoria das leis, e que a maior parte da halachá é, de fato, oral.

Do ponto de vista religioso, no entanto, tal distinção tem pouca importância, pois mesmo as leis definidas oralmente pelos sábios são consideradas como dadas diretamente a Moisés no Sinai, como já discutido anteriormente. Esse modo de encarar as coisas é uma forma de dizer que mesmo as leis orais dos sábios são divinas e legítimas.

No entanto, alguns teóricos do judaísmo também são contra esse tipo de explicação dogmática das leis. Rambam, filósofo lúcido e crítico que era, no Sêfer Hamitsvót (Livro dos Mandamentos) deixa bem claro que não se deve considerar como um dos 613 mandamentos nada que seja derivado de um dos treze métodos de interpretação da Torá utilizado pelos sábios (isso não quer dizer, no entanto, que para o Rambam as leis derivadas por métodos interpretativos não devem ser seguidas).

Feita a distinção entre os 613 mandamentos da Torá por oposição a todos os outros criados por sábios, o Rambam, em sua introdução ao Volume de Zeraim da Mishná (vide a seguir), explicita que toda lei controversa é uma lei que foi deduzida por inferência racional (sem cunho divino) e critica ferozmente aqueles que afirmam que todas as leis judaicas foram dadas a Moisés no Sinai:

Todo aquele que acha que as leis sobre as quais eles discordaram também foram dadas a Moisés, e aqueles que acham que houve um desentendimento entre eles por causa de um erro na halachá, ou por conta do esquecimento, ou porque um deles tinha a tradição correta e o outro estava enganado... todos estes estão falando palavras de pessoas insensatas, e essas pessoas não têm princípio algum, além de estarem difamando as pessoas de quem os mandamentos realmente foram recebidos... Pois eles [esses que estão em erro] dizem que qualquer interpretação aceitável vem de Moisés e é verdadeira, e eles não fazem distinção alguma entre os princípios aceitos e a história do assunto que levou a questão a ser discutida. 


\section{BIBLIOGRAFIA}

ABRAHAM, M.; GABBAY, D. M.; SCHILD, U. Analysis of the Talmudic Argumentum A Fortiori Inference Rule (Kal-Vachomer) using Matrix Abduction. Studia Logica, p. 281-364, set. 2009.

ALBECK, H. Semichá, Minui ve Beit Din. In: Tsion, v. 8, 1943.

ALBECK, H. Mavô la Mishná. Jerusalém: Mossad Bialik, 2005.

ALBECK, S. Mavô le Mishpat Haivri bimê Hatalmud. Ramat Gan: Universidade Bar Ilan, 1999.

ALON, M. Hamishpat Haivri. Jerusalém: Magnes, 1988.

AMÂNCIO, M. O Talmud. São Paulo: Iluminuras, 1992.

AVOT de Rabi Natan (Mevoar - Lefi Nussachat Ha Gra). Jerusalém: Sifrei Ramot.

BACHER, B. Z. Archê Midrash. Tel Aviv: [s.n.], 1922.

BARR, J. History of Israel. In: History and Ideology in the Old Testament. Oxford: Oxford University Press, 2000.

BECHAIE, R. Biur al Hatorá. Jerusalém: Mossad Harav Kook.

BERGMAN, M. Z. Gateway to the Talmud. History, development and principles of Torah she'b'al peh - from Moses to the Baal Shem Tov and Vilna Gaon. [S.1.]: Art Scroll Mesorah Series, 1985.

BERKOWITZ, B. Execution and Invention: Death Penalty Discourse in Early Rabbinic and Christian Cultures. Nova Iorque: Oxford University Press, 2006.

CARDOZO, N. The Infinite Chain: Torah, Masorah, and Man. Nova Iorque: Philip Feldheim, 1989.

CHAIT, I. Why One Should Learn Torah. Disponível em <https://www.mesora.org/whylearn.html> e seguinte. Acesso em: 5 dezembro 2014.

CUNDALL, A. E. The United Monarchy: Fact or Fiction? In: Vox Evangelica, v. 8, 1973. 
ENCICLOPÉDIA TALMUDIT. Proiect Hashut/Responsa 19+. Ramat Gan: Universita Bar Ilan. Programa digital em USB.

EPSTEIN, J. N. Mevoot Lesifrut Hatanaím. Tel Aviv: Devir, 1957.

EVEN-SHOSHAN, A. Milon Even-Shoshan. [S.1.]: [s.n.], 2003.

FINKELSTEIN, L. (Ed.). Sifri al Sêfer Devarim. Nova Iorque: Beit Midrash Larabanim she be America, 1993.

FINKELSTEIN, I.; SILBERMAN, N. A. The Bible Unearthed: Archaeology's New Vision of Ancient Israel and the Origin of Its Sacred Texts. Nova Iorque: Simon and Schuster, 2001.

FITZMYER, J. A. The Impact of the Dead Sea Scrolls, [S.1] Paulist Press, 2009. p 56.

FRANKEL, Z. Darchê Hamishná. Varsóvia: Cailengold, 1923.

GOLDBERG, A. Derachim shel tsimtsum machloket etsel amoraê Bavel. In: ZUSSMAN, D. R. Mechakrê Talmud. Jerusalém: Magnes, 2005.

GORODOVITS, D.; FRIDLIN, J. (Eds.). Bíblia Hebraica. São Paulo: Sêfer, 2006.

GUILAT, I. D. Biná bamishná. [S.1]: Sinai, 1958.

GUILAT, I. D. Michtam leDavid. Ramat Gan: Universidade Bar Ilan, 1979.

GUILAT, I. D. Perakim behishtalshelut hahalachá. Ramat Gan: Universidade Bar Ilan, 1992.

HARRIS, S. L. Understanding the Bible. Palo Alto: Mayfield, 1985.

HALEVI, I. Sêfer Hacuzarí. Tel Aviv: Devir, 1973.

HALIVNI, D. W. Peshat and Derash: Plain and Applied Meaning in Rabbinic Exegesis. Nova Iorque: Oxford University Press, 1998.

HALIVNI, D. W. The Formation of the Babylonian Talmud. Nova Iorque: Oxford University Press, 2013.

HERBERT, D. The Mishnah: Translated from the Hebrew with Introduction and Brief Explanatory Notes. Peabody: Hendrickson Publishers, 2012. 
HIRVONEN, A. Promising Justice: Derrida with Jewish Jurisprudence. [S.1], 2001.

IEHUDA, E. B. Milon Halashon Haivrit Haieshená Vehachadashá. [S.1.]: T. Yoseloff, 1960. JASTROW, M. A Dictionary of the Targum, the Talmud Babli and Jerushalmi, and the Midrashic Literature. Leipzig: Drugulin, Oriental Printer, 1903.

JEWISH ENCYCLOPEDIA. Disponível em <http://www.jewishencyclopedia.com/>. Acesso em: 3 janeiro 2014.

KEHATI, P. (Ed.). Mishnaiót Mevoarot. Jerusalém: Chemed, 2003.

KHAFIF, M. Derech Limud. São Paulo: Lubavitch, 2006.

KUHRT, A. The Ancient Near East. Londres: Routledge, 1995.

KLEINMAN (Ed.). Midrash Rabá. Nova Iorque: ArtScroll/Mesorah Publications, 2011.

KOLTUN-FROMM, K. Abraham Geiger's liberal Judaism. Indianda: Indiana University Press, 2006. p 53.

KOPPEL, M. Meta-Halakha. Logic, Intuition and the Unfolding of Jewish Law. Northvale, Nova Jérsei, Londres: Jason Aronson Inc., 1987.

LAUTERBACH, J. Z. (Ed.). Mechilta de Rabi Ishmael. Filadélfia: The Jewish Publication Society, 2004.

LIEBERMAN, S. (Ed.). Tossefta al pi ktav iad Viena. Nova Iorque: Beit Midrash Larabanim she be America, 1955-1988.

LIEBERMAN, S. Ievanit ve Ievanut be Erets Israel. Jerusalém: Mossad Bialik, 1984.

LOWY, S. The Principles of Samaritan Bible Exegesis. [S.1] Brill Archive, 1977. pp. 25-28. MELAMED, E. T. Pirkê Mavô le Sifrut Hatalmud. Jerusalém: [s.n.], 1973.

MELAMED, M. M. Pirkei Avoth: Ethics of the Fathers (Bilingual edition). Tradução de David Altabe. Nova Jérsei: Ktav Pub Inc., 2007.

RAMBAM. Pêrush Hamishnaiót. Hannover: Peraynsbukhruḳerai, 1906.

RAMBAM. Mishnê Torá. Rambam Laam. ed. Jerusalém: Mossad Harav Kook, 1957-1961. 
RASHI. The Complete Jewish Bible with Rashi Commentary. Chabad. Disponivel em: <http://www.chabad.org/library/bible_cdo/aid/63255/jewish/The-Bible-withRashi.htm>. Acesso em: 31 maio 2013.

SCHARFSTEIN, S. Torah and Commentary: The Five Books of Moses: Translation, Rabbinic and Contemporary Commentary. Nova Jérsei: Ktav Publishing House, 2008. SCHARFSTEIN, S.; GELABERT D. Understanding Jewish History: From the patriarchs to the expulsion from Spain. Nova Jérsei: Ktav Publishing House, 1996.

SION, A. Judaic Logic. A Formal Analysis of Biblical, Talmudic and Rabbinic Logic. [S.1.]: Slatkine, 1997.

STEINSAlTZ, A. (Ed.). Talmud Bavli. Jerusalém: Hamachon Haisraeli Lepirsumim Talmudiim, 1969-1985.

STEINSAltZ, A. The Talmud, The Steinsaltz Edition: A Reference Guide. Maryland: Random House Inc., 1989.

STUDENT, G. Proofs for the Oral Torah. Aishdas. Disponível em: < http://www.aishdas.org/student/oral.htm>. Acesso em: 21 novembro 2014.

TALMUD Ierushalmi im Peirushim (tsilum dfus Vilna). Jerusalém: [s.n.].

TELUSHKIN, J. Jewish Literacy: Revised Edition. Nova Iorque: William Morrow and Company, Inc., 2001.

URBACH, E. E. Halacha and Prophecy. In: Tarbiz, v. 18, 1947, pp. 1-27.

URBACH, E. E. The Sages: Their Concepts and Beliefs. Jerusalém: Hebrew University Magnes Press, 1975.

URBACH, E. E. Halachá - Mecoroteia ve Hitpatchuta. Givatáim: Massada, 1984.

VAUX, R. D. Ancient Israel: Its Life and Institutions. Grand Rapids: Wm. B. Eerdmans Publishing, 1997.

VRIES, B. D. Toldot Hahalachá Hatalmudit. Tel Aviv: A. Tsioni, 1966. 
WEISS, I. H. (Ed.). Sifra de vê Rav hú sêfer torát cohanim. Viena: Mekhon Ofek, 1862. WILLIAMSON, H. G. M. Ezra and Nehemiah. Sheffield: Sheffield Academic Press, 1987 ZILBERG, M. Cach Darcô shel Talmud. Jerusalém: Universidade Hebraica de Jerusalém, 1961. 